
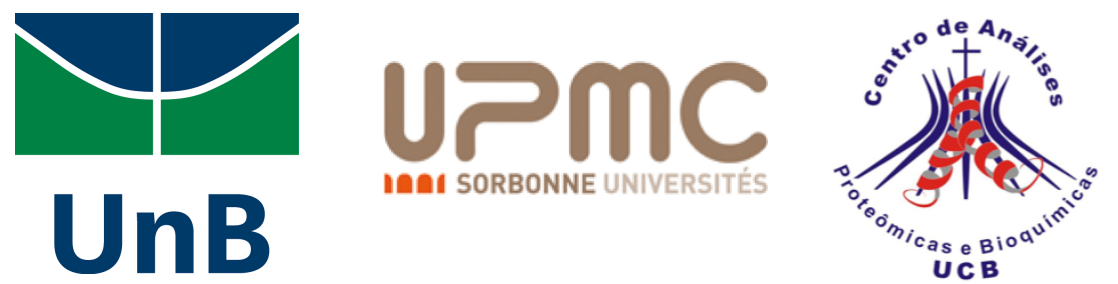

Programa de Pós-Graduação em Patologia Molecular, Faculdade de Medicina, Universidade de Brasília École Doctorale Complexité du Vivant, Université Pierre et Marie Curie, Paris VI Centro de Análises Proteômicas e Bioquímicas, Universidade Católica de Brasília Laboratoire Biogenèse des Signaux Peptidiques (BIOSIPE), Institut de Biologie Paris Seine

\title{
Avaliação estrutural e funcional de novos peptídeos antimicrobianos obtidos a partir de desenho racional
}

Doutoranda: Luz Noemí IRAZAZABAL

Orientador: Prof. Dr. Octávio Luiz FRANCO, UCB/UnB, Brasília, Brasil Co-Orientador: Prof. Dr. Ali LADRAM, UPMC, Paris, França 


\section{LUZ NOEMI IRAZAZABAL}

\section{AVALIAÇÃO ESTRUTURAL E FUNCIONAL DE NOVOS PEPTÍDEOS ANTIMICROBIANOS OBTIDOS A PARTIR DE DESENHO RACIONAL}

Tese apresentada ao Programa de Pós-Graduação em

Patologia Molecular da Universidade de Brasília e ao École Doctorale Complexité du Vivant de l'Université Pierre et Marie Curie Paris VI, como requisito parcial para obtenção do grau de Doutor da Universidade de Brasília e Doutor da Université Pierre et Marie Curie.

Orientador: Prof. Dr. Octávio Luiz FRANCO, UCB/UnB Co-orientador: Prof. Dr. Ali LADRAM, UPMC 


\section{AGRADECIMENTOS}

Ao meu orientador, Professor Octávio Franco, primeiro pela confiança em mim depositada, sendo meu "caso complicado" não hesitou em me brindar um espaço na sua equipe do Centro de Análises Proteômicas e Bioquímicas (o CAPB, certamente uma grande equipe). Obrigada por me dar seu apoio e por acreditar (e me transmitir) desde o início que eu conseguiria fazer um bom trabalho. Obrigada por ser um verdadeiro orientador, desses que sabem tirar o melhor de cada aluno, ajudando-o a desenvolver pensamento crítico, independente e científico. Reitero, ao Prof. Oct, meu sincero agradecimento, profunda admiração e grande carinho!

Je tiens à remercier vivement le professeur Ali Ladram d'avoir bien voulu accepter d'être mon co-directeur de thèse, malgré mon "cas compliqué". Merci pour la confiance accordée dès le début et sans laquelle je n'aurais jamais réussi à apprendre autant durant le peu de temps dont je disposais pour le stage. Merci pour le soutien, les enseignements de qualité sur le domaine et les corrections, qui m'ont permis de mener à bien ce projet. Merci beaucoup Ali de m'avoir encadrée, c'est grâce à l'opportunité que tu m'as offerte que j'ai pu reprendre mon "chemin scientifique"!

J'exprime ma gratitude au directeur du laboratoire, le professeur Thierry Foulon, pour sa gentillesse et pour m'avoir permis de réaliser ce stage au sein de son équipe Biogenèse des Signaux Peptidiques (BioSiPe).

À toute l'équipe du laboratoire à Paris, pour leur accueil tellement aimable et chaleureux, chacun a su rendre mon stage agréablement inoubliable. Je tiens également à remercier Christophe pour la synthèse des peptides!

Un merci bien particulièrement adressé à Sónia (aussi Dr. André), c'était grâce au temps que tu as dédié à m'apprendre les manips que j'ai réussi à faire une grande partie des travaux de cette thèse. Merci pour la patience, la sympathie, les discussions sur mes résultats (et sur la vie...hihihi) qui ont contribué à la qualité du travail accompli... ainsi que les pauses café et les sorties détentes :) Je serai toujours reconnaissante d'avoir eu la chance de travailler avec toi!

Je n'oublie pas de remercier profondément Mme Muriel Umbhauer, ancienne directrice de I'ED, qui n'a pas hésité à exercer sa fonction avec impartialité, objectivité et professionnalisme.

Aos professores membros da banca por disporem generosamente de seu tempo para a leitura e discussão deste trabalho e pelos pertinentes apontamentos que engrandeceram a versão final da tese.

Aos meus colegas de laboratório de Brasília por estarem sempre disponíveis a me auxiliar no trabalho e pelos momentos descontraídos cheios de risos. A todos, obrigada 
por me fazer esquecer a saudade de casa. Em especial, obrigada William pelo seu trabalho anterior que serviu de base para começar minha pesquisa e pela paciência para responder minhas perguntas a respeito.

Aos meus amigos Edemir e Thomas, agradeço ao destino (ou será que devo agradecer ao Nonato?!) ter nos colocado no mesmo apartamento da Colina. Estou muito feliz de ter compartilhado esses anos cheios de conversas apaixonantes, de saídas incrivelmente divertidas, de filmes e livros e peças de teatro e passeios na natureza que espero possamos continuar compartilhando por sempre. Obrigada pelas nossas rodas de chimarrão e mate, pelo suporte nos momentos difíceis que tive que passar, pelo apoio, pelos conselhos e por me permitir conhecer vocês cada dia mais. Los quiero muchísimo!!

A mis amigas, Les Filles, que siempre me acompañaron (y me aguantaron) en las buenas y en las malas. Porque la distancia que nos separa nunca fue un obstáculo en nuestra amistad incondicional. Son mi cable a tierra, mis "media-naranja”. Las amo!!

A Carlos, por insistirme a no bajar los brazos. Sin tu ayuda no hubiera llegado hasta acá.

A mi familia que banca mis locuras, me apoya siempre y me da libertad para salir a cumplir mis sueños. Gracias por el aguante. Los adoro!!

Agradeço ao CNPq e à CAPES pelas bolsas de estudo concedidas.

Finalmente, agradeço a todos aqueles que colocaram obstáculos durante este caminho. Graças a esses impedimentos, aprendi e cresci ainda mais, tanto profissionalmente, quanto pessoalmente. Eles me permitiram ganhar mais confiança, me oportunizaram lutar pelo certo e pelo justo. Hoje, não apenas finalizo meu trabalho como doutoranda, como me considero uma mulher mais forte. Gracias! 
Para mamá, minha "desenhadora" 


\begin{abstract}
Antimicrobial peptides (AMPs) have been considered as a potential novel class of antimicrobial compounds. In order to generate new potent and non-toxic antimicrobial agents, rational design strategies may be employed. In this view, we used a computational method to design three synthetic AMPs ([I $\left.{ }^{5}, \mathrm{R}^{8}\right]$ MP, EcDBS1R6 and PaDBS1R1). By determining the minimum inhibitory concentration, we found that all the peptides were active against Gram-negative and -positive bacteria. Only $\left[\mathrm{I}^{5}, \mathrm{R}^{8}\right] \mathrm{MP}$ was found to display antifungal activity. The determination of the peptide concentration producing $50 \%$ of cell lysis revealed low or no hemolytic activity, with no cytotoxicity towards human embryonic kidney cells HEK-293. During time-kill assays more rapid bactericidal effects were observed for PaDBS1R1 and $\left[\mathrm{I}^{5}, \mathrm{R}^{8}\right] \mathrm{MP}$ against $E$. coli compared to $S$. aureus. For the peptide EcDBS1R6, identical killing curves were obtained for both bacterial strains. Membrane permeabilization and depolarization studies combined with field emission gun scanning electron microscopy (SEM-FEG) revealed that a membranolytic mechanism occurs for these peptides. When analyzed by circular dichroism and nuclear magnetic resonance microscopy or by molecular dynamics simulations during interaction with a membrane model, peptides were shown to adopt an amphipathic alpha-helical conformation. In conclusion, our results indicate that the structural and functional evaluation of rationally designed synthetic AMPs represents a promising strategy for the development of potent novel antimicrobial agents.
\end{abstract}

Keywords: infectious diseases, antimicrobial resistance, antimicrobial peptides, rational design, structure, therapeutic potential. 


\section{RESUMO}

As infecçõesrelacionadas à assistência à saúde e o surgimento de cepas bacterianas resistentes aos antibióticos de uso convencional, representam um dos principais problemas de saúde pública. Neste contexto, os peptídeos antimicrobianos (AMPs) têm sido considerados como uma potencial nova classe de compostos antimicrobianos. Objetivando a geração de novos agentes antimicrobianos potentes e não tóxicos, com potencial terapêutico, estratégias de desenho racional podem ser utilizadas para otimizar AMPs existentes ou para produzir novos AMPs com caraterísticas desejáveis. Nesta perspectiva, foi utilizada uma abordagem racional para gerar três peptídeos sintéticos ([I ${ }^{5}$, $\mathrm{R}^{8}$ ] MP, EcDBS1R6 e PaDBS1R1) e avaliar suas propriedades estruturais e funcionais. Mediante a determinação da concentração mínima inibitória (CMI), observou-se que todos os peptídeos mostraram atividade contra bactérias Gram-negativas (CMI = 1,5 $12,5 \mu \mathrm{M})$ e Gram-positivas $(\mathrm{CMI}=3,125-50 \mu \mathrm{M})$. Apenas $\left[\mathrm{I}^{5}, \mathrm{R}^{8}\right] \mathrm{MP}$ apresentou atividade antifúngica contra Candida albicans com um valor de CMI baixo (12,5 $\mu \mathrm{M})$. A determinação da concentração de peptídeo capaz de reduzir em 50\% a viabilidade celular, revelou baixa ou nula atividade hemolítica $\left(\mathrm{LC}_{50}>200 \mu \mathrm{M}\right.$ para os peptídeos $\left[\mathrm{I}^{5}, \mathrm{R}^{8}\right] \mathrm{MP}$ e EcDBS1R1; $\mathrm{LC}_{50}=50 \mu \mathrm{M}$ para PaDBS1R1), e ausência de citotoxicidade frente a células renais embrionárias humanas HEK-293 $\left(\mathrm{LC}_{50} \sim 111-143 \mu \mathrm{M}\right)$. A cinética da atividade bactericida revelou uma rápida ação bactericida de PaDBS1R1 e $\left[\mathrm{I}^{5}, \mathrm{R}^{8}\right] \mathrm{MP}$ frente a $E$. coli $(<5$ e 15 min, respectivamente) e moderada frente a $S$. aureus $(30$ e 45 min, respectivamente). No caso de EcDBS1R1, observou-se rápido efeito bactericida para ambas espécies bacterianas (15 min). Os ensaios de permeabilização e despolarização combinados às imagens de microscopia eletrônica de varredura com fonte de emissão de campo (MEV-FEG), indicaram que os peptídeos podem ser capazes de alterar a integridade da membrana bacteriana por meio de um mecanismo membranolítico. A análise da estrutura dos peptídeos por espectroscopia de dicroísmo circular e ressonância magnética nuclear, bem como a simulação por dinâmica molecular in silico em ambiente de membrana, revelou uma conformação $\alpha$-hélice anfipática. Em conclusão, os resultados indicam que a avaliação estrutural e funcional dos AMPs sintéticos racionalmente desenhados, representa uma estratégia promissora para o desenvolvimento de novos agentes antimicrobianos como uma nova classe de fármacos com vista a abordar a problemática da resistência aos antibióticos.

Palavras chave: doenças infecciosas, resistência antimicrobiana, peptídeos antimicrobianos, desenho racional, estrutura, potencial terapêutico. 


\section{RESUMÉ}

Les peptides antimicrobiens sont considérés comme une nouvelle classe prometteuse d'agents anti-infectieux. Afin de développer de nouveaux agents efficaces et non toxiques, des stratégies de conception rationnelle peuvent être utilisées. Dans cette perspective, nous avons utilisé une approche computationnelle pour concevoir trois

peptides synthétiques $\left(\left[\mathrm{I}^{5}, \mathrm{R}^{8}\right] \mathrm{MP}\right.$, EcDBS1R6 et PaDBS1R1). En déterminant la concentration minimale inhibitrice, nous avons montré que tous les peptides sont actifs contre les bactéries Gram-négatif et -positif. Seul $\left[\mathrm{I}^{5}, \mathrm{R}^{8}\right]$ MP a montré une activité antifongique. La mesure de la concentration de peptide provoquant $50 \%$ de mortalité cellulaire a permis de montrer que les peptides étaient faiblement ou non hémolytiques, sans toxicité vis-à-vis des cellules embryonnaires rénales humaines HEK-293. La cinétique bactéricide a révélé que PaDBS1R1 et $\left[\mathrm{I}^{5}, \mathrm{R}^{8}\right]$ MP tuent rapidement $E$. coli en comparaison à $S$. aureus et que EcDBS1R6 élimine rapidement les deux souches. Des études de perméabilisation et de dépolarisation combinées à de la microscopie électronique à haute résolution (FEG-SEM) ont montré un mécanisme membranolytique des peptides. L'analyse de la structure des peptides par spectroscopie de dichroïsme circulaire et résonance magnétique nucléaire, ainsi que par modélisation moléculaire lors de leur interaction avec une membrane modèle, révèle une conformation en hélice alpha amphipatique. En conclusion, notre étude indique que l'évaluation structurale et fonctionnelle de peptides antimicrobiens synthétiques conçus de manière rationnelle représente une stratégie prometteuse pour le développement de nouveaux agents antimicrobiens.

Mots clés : maladies infectieuses, résistance aux antibiotiques, peptides antimicrobiens, conception rationnelle, structure, potentiel thérapeutique. 
LISTA DE ABREVIATURAS

\begin{tabular}{|c|c|}
\hline$\%$ & Porcentagem \\
\hline AMPs & Peptídeos antimicrobianos (do inglês, antimicrobial peptides) \\
\hline ATCC & American type culture collection \\
\hline DC & Dicroísmo circular \\
\hline Da & Dalton \\
\hline DMEM & $\begin{array}{l}\text { Meio Dulbecco modificado (do inglês, Dulbecco's Modified Eagle's } \\
\text { Medium) }\end{array}$ \\
\hline DMSO & Dimetilsulfóxido \\
\hline DNA & Ácido desoxirribonucleico \\
\hline DOPC & Dioleoilfosfatidilcolina \\
\hline Fmoc & 9-fluorenilmetoxicarbonila \\
\hline $\mathbf{h}$ & Horas \\
\hline HEPES & Ácido N-(2-hidroxietil)piperacina-N'-(2-etanosulfônico) \\
\hline IRAS & Infecções Relacionadas à Assistência à Saúde \\
\hline $\mathbf{L}$ & Litros \\
\hline LPS & Lipopolissacarídeos \\
\hline $\mathbf{M}$ & Molar \\
\hline $\mathbf{m} / \mathbf{z}$ & Relação massa carga \\
\hline MALDI-ToF MS & $\begin{array}{l}\text { Matrix Assisted Laser Desorption Ionization Time-of-Flight Mass } \\
\text { Spectrometry }\end{array}$ \\
\hline MDR & Resistência à múltiplas drogas, do inglês Multi Drug Resistance \\
\hline CMI & Concentração mínima inibitória \\
\hline $\min$ & Minutos \\
\hline $\mathbf{m L}$ & Mililitros \\
\hline MTT & 3-(4,5-di-metilazol-2-il)-2,5-difenil tetrazolium brometo \\
\hline $\mathbf{n m}$ & Nanômetros \\
\hline ns & Nanosegundos \\
\hline NCBI & National Center for Biotechnology Information \\
\hline${ }^{\circ} \mathbf{C}$ & Graus celsius \\
\hline PBS & Tampão fosfato salino \\
\hline PBP & Proteínas de ligação a penicilinas \\
\hline PDB & Banco de dados de proteínas, do inglês protein data bank \\
\hline $\mathbf{R M N}$ & Ressonância magnética nuclear \\
\hline RPM & Rotações por minuto \\
\hline SDS & Dodecil sulfato de sódio \\
\hline $\mathbf{U V}$ & Ultravioleta \\
\hline UFC & Unidade formadora de colônia \\
\hline$\mu \mathrm{g}$ & Microgramas \\
\hline$\mu \mathbf{L}$ & Microlitro \\
\hline$\mu \mathrm{M}$ & Micromolar \\
\hline
\end{tabular}




\section{CÓDIGO DOS AMINOÁCIDOS}

Aminoácidos

Alanina

Arginina

Asparagina

Aspartato

Cisteína

Glutamina

Glutamato

Glicina

Histidina

Isoleucina

Leucina

Lisina

Metionina

Fenilalanina

Prolina

Serina

Treonina

Triptofano

Tirosina

Valina

\section{Código (1 letra)}

A

$\mathrm{R}$

$\mathrm{N}$

D

C

Q

E

G

$\mathrm{H}$

I

$\mathrm{L}$

K

M

F

P

S

$\mathrm{T}$

W

Y

V

\section{Código (3 letras)}

Ala

Arg

Asn

Asp

Cys

Gln

Glu

Gly

His

Iso

Leu

Lys

Met

Phe

Pro

Ser

Thr

$\operatorname{Trp}$

Tyr

Val 


\section{LISTA DE FIGURAS}

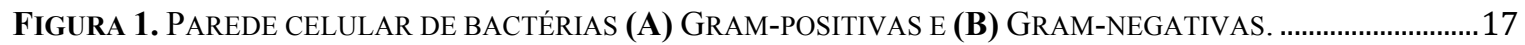

FIGURA 2. ESTRUTURA DE PAREDE CELULAR DO FUNGO CANDIDA ALBICANS.....................................................18

FIGURA 3. MECANISMOS DE RESISTÊNCIA BACTERIANA AOS AGENTES ANTIMICROBIANOS. ...............................21

FIGURA 4. REPRESENTAÇÃO DAS CLASSES ESTRUTURAIS DE AMPS. ....................................................................2

FIGURA 5. MODELOS DE INTERAÇÃO ENTRE OS AMPS E A MEMBRANA BACTERIANA ............................................32

Figura 6. (A) Alinhamento dAs SEQuÊNCIAS (ACIMA) E PROJEÇÕES DE HÉliCE (ABAiXO) DO PEPTÍDEO

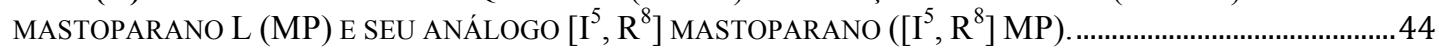

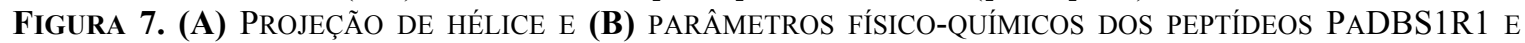
ECDBS1R6.

FIGURA 8. ESPECTROS DE MASSAS GERADOS NO EQUIPAMENTO MALDI-TOF, PARA OS PEPTÍDEOS SINTÉTICOS. 65

FigurA 9. EFEITO DE $\left[\mathrm{I}^{5}, \mathrm{R}^{8}\right]$ MP SOBRE A INTEGRIDADE DA MEMBRANA PLASMÁtiCA DE E. COLI ATCC 25922 E $S$. AUREUS ATCC 25923

Figura 10. CinéticA DA MORTE CELUlAR DE E. COLI ATCC 25922 (TRIÂNGUlos BRANCOS) E S. AUREUS ATCC 25923 (Ć́RCUlos BRANCOS) APÓS INCUBAÇÃo COM $25 \mu \mathrm{M}$ E $50 \mu \mathrm{M}$ DE [I $\left.\mathrm{I}^{5}, \mathrm{R}^{8}\right] \mathrm{MP}$, RESPECTIVAMENTE (DOBRO DA CMI).

Figura 11. IMAGENS OBTIDAS POR MEV-FEG DO EFEITO DE $\left[\mathrm{I}^{5}, \mathrm{R}^{8}\right]$ MP SOBRE AS CÉLULAS DE (A-C) $P$. AERUGINOSA ATCC 27853, (D-F) L. IVANOVII LI 4PVS2 E (G-I) C. ALBICANS ATCC 90028....................73

FigURA 12. PREDIÇÃO DA ESTRUTURA TRIDIMENSIONAL DE $\left[\mathrm{I}^{5}, \mathrm{R}^{8}\right]$ MASTOPARANO.........................................74

FigurA 13. EFEITO DE ECDBS1R6 SOBRE A INTEGRIDADE DA MEMBRANA PLASMÁtiCA DE E. COLI ATCC 25922 E $S$. AUREUS ATCC 25923.

Figura 14. CinéticA DA MORTE CELUlAR DE E. COLI ATCC 25922 (TRiÂNGUlos BRANCOS) E S. AUREUS ATCC 25923 (CÍRCULOS BRANCOS) APÓS INCUBAÇÃO COM 6,25 $\mu \mathrm{M}$ DE ECDBS1R6 (DOBRO DA CMI).

Figura 15. IMAGENS OBTIDAS POR MEV-FEG DO EFEITO DE ECDBS1R6 SOBRE AS CÉlULAS DE (A-D) $P$. AERUGINOSA ATCC 27853 E (E, F) L. IVANOVII LI 4PVS2 . .........................................................................8

FIGURA 16. PREDIÇÃO DA ESTRUTURA TRIDIMENSIONAL DE ECDBS1R6. ............................................................81

Figura 17. EFEITO DE PADBS1R1 SOBRE A INTEGRIDADE DA MEMBRANA PLASMÁtiCA DE E. COLI ATCC 25922 E $S$. AUREUS ATCC 25923.

Figura 18. CinéticA dA MORTE CELUlAR DE E. COLI ATCC 25922 (TRiÂNGUlos BRANCOS) E S. AUREUS ATCC 25923 (CÍRCUlOS BRANCOS) APÓS INCUBAÇÃO COM 6,25 $\mu \mathrm{M}$ DE PADBS1R1 (DOBRO DA CMI).

86

Figura 19. IMAGENS ObTidas POR MEV-FEG do EFEITO DE PADBS1R1 Sobre as CÉlulas de (A-C) $P$. AERUGINOSA ATCC 27853 E (D-F) L. IVANOVII LI 4PVS2...

Figura 20. ANÁLISE DA ESTRUTURA TRIDIMENSIONAL DE PADBS1R1 91

\section{LISTA DE TABELAS}

TABEla 1. Agentes ANTIMICROBIANOS E Sítios DE INFECÇÕESMAis FREQUENTES NAS DOENÇAS INFECCIOSAS NOSOCOMIAIS (ANVISA, 2004).

TABELA 2. MECANISMOS DE AÇÃo DOS AGENTES ANTIMICROBIANOS (TENOVER, 2006) ....................................20

TABELA 3. PARÂMETROS PARA AQUISIÇÃO DE EXPERIMENTOS DE RMN .................................................................61

TABELA 4. SEQUÊNCIAS DESENHADAS SELECIONADAS PARA AVALIAÇÃO FUNCIONAL.........................................64

TABEla 5. ESPECTRO DE ATIVIDADES ANTIMICROBIANA E CitOTÓXICA DE $\left[\mathrm{I}^{5}, \mathrm{R}^{8}\right]$ MASTOPARANO E $\left[\mathrm{I}^{5}, \mathrm{R}^{8}\right]$ MASTOPARANO-AMIDA.

TABELA 6. ESPECTRO DE ATIVIDADES ANTIMICROBIANA E CITOTÓXICA DE ECDBS1R6 ...................................75

TABELA 7. EsPeCtro DE ATIVIDADES ANTIMICROBIANA E CitOTÓXICA DE PADBS1R1 E PADBS1R1-AMIDA.

TABEla 8. ESPECTRO DE ATIVIDADES ANTIMICROBIANA E CITOTÓXICA DOS 5 PEPTÍDEOS RACIONALMENTE DESENHADOS. 


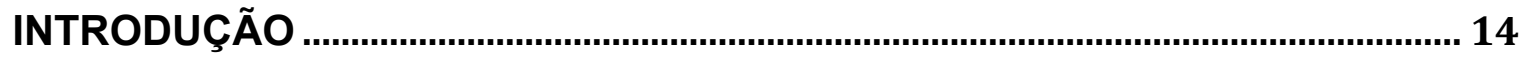

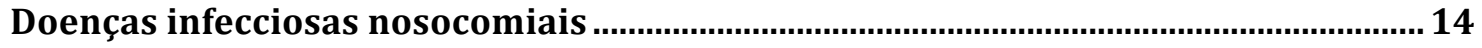

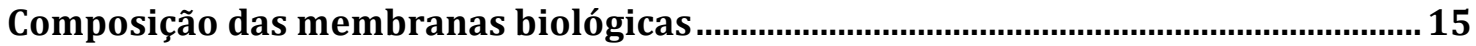

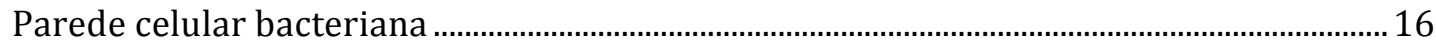

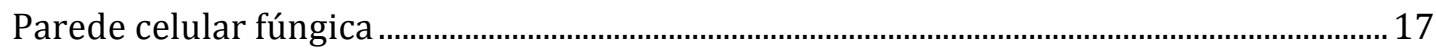

Antimicrobianos utilizados no tratamento das infecções e mecanismos de

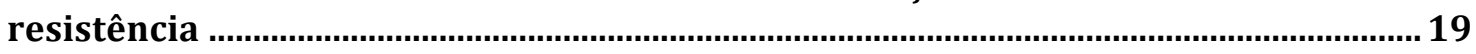

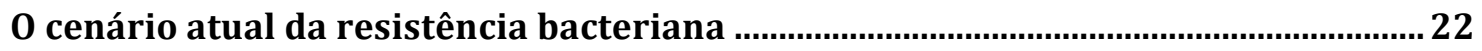

Peptídeos antimicrobianos (AMPs): uma nova fronteira no controle da infecção

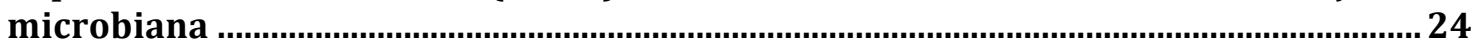

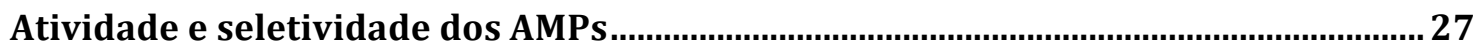

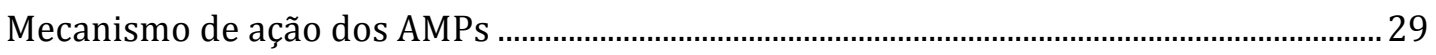

Determinantes estruturais dos AMPs para a atividade antimicrobiana .........................33

Abordagens computacionais para o desenvolvimento de novos AMPs.........................38

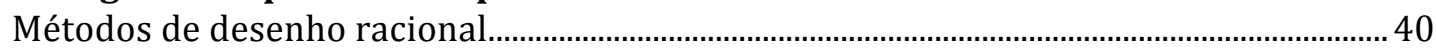

Desenho racional de sequências para o trabalho ..........................................................44

Substituição de aminoácidos no peptídeo mastoparano L........................................................ 44

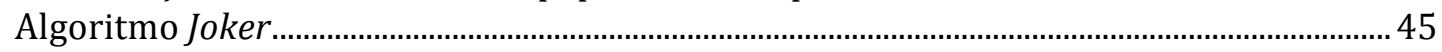

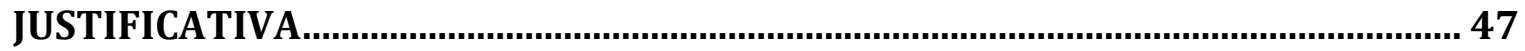

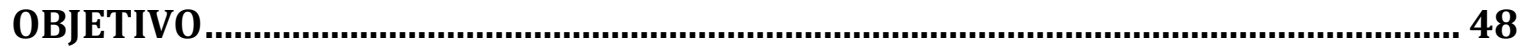

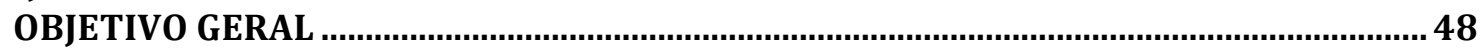

OBJETIVOS ESPECÍFICOS.................................................................................................... 48

MATERIAL E MÉTODOS....................................................................................... 49

Desenho racional de peptídeos antimicrobianos: método baseado em sequência

modelo ............................................................................................................................ 49

Substituição de aminoácidos ......................................................................................................................49

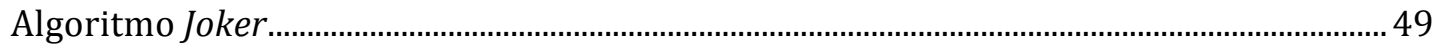

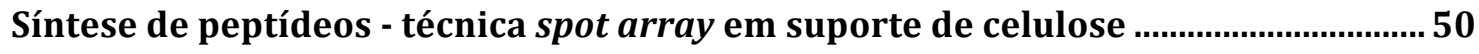

Determinação da atividade antimicrobiana frente a P. aeruginosa bioluminiscente

Síntese dos peptídeos escolhidos e confirmação da identidade por espectrometria

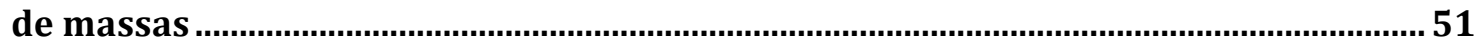

Determinação da concentração mínima inibitória (CMI) antibacteriana ...................52

Determinação da concentração mínima inibitória (CMI) antifúngica ...........................53

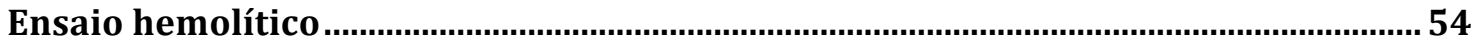

Avaliação citotóxica dos peptídeos in vitro ................................................................54

Avaliação da permeabilização de membranas bacterianas induzida por peptídeos

Avaliação da despolarização de membranas bacterianas induzida por peptídeos 57

Ensaios time-kill ..............................................................................................................58

Microscopia eletrônica de varredura com fonte de emissão de campo (MEV-FEG) 58

Experimentos de espectroscopia de dicroísmo circular.................................................59

Experimentos de RMN .......................................................................................................60

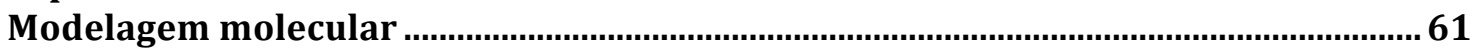

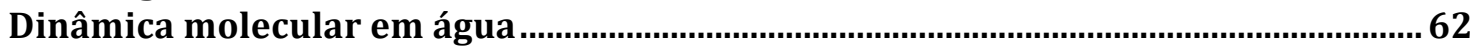

Dinâmica molecular em membrana DOPC ………………..............................................63

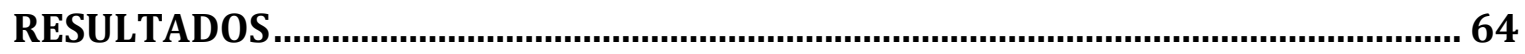

Desenho racional e seleção de sequências ...............................................................................64

Confirmação da identidade e pureza dos peptídeos por espectrometria de massas........ 64

Parte 1: Estudo estrutural e funcional do análogo $\left[I^{5}, R^{8}\right]$ mastoparano ......................66

1.1. Espectro de atividade antimicrobiana .........................................................................................66

1.2. Atividade hemolítica e citotóxica sobre linhagens celulares humanas ..........................67 
1.3. Permeabilização e despolarização da membrana bacteriana............................................6 68

1.4. Cinética da atividade antibacteriana in vitro ………........................................................ 71

1.5. Visualização da atividade antimicrobiana por MEV-FEG ……………………………... 72

1.6. Análise in silico da estrutura tridimensional e interação com membrana DOPC...... 73

Parte 2: Estudo estrutural e funcional do peptídeo desenhado EcDBS1R6 .................75

2.1. Espectro de atividade antimicrobiana .............................................................................. 75

2.2. Atividade hemolítica e citotóxica sobre linhagens celulares humanas ..........................75

2.3. Permeabilização e despolarização da membrana bacteriana........................................... 76

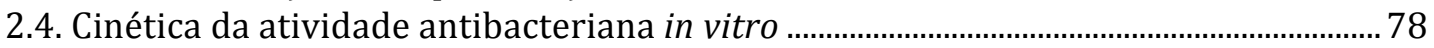

2.5. Visualização da atividade antimicrobiana por MEV-FEG ……………………................ 78

2.6. Análise in silico da estrutura tridimensional e interação com membrana DOPC...... 80

Parte 3: Estudo estrutural e funcional do peptídeo desenhado PaDBS1R1 ................ 82

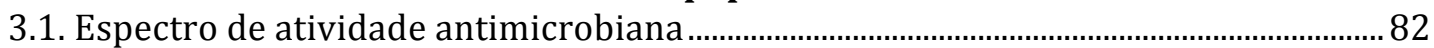

3.2. Atividade hemolítica e citotóxica sobre linhagens celulares humanas ......................... 83

3.3. Permeabilização e despolarização da membrana bacteriana............................................ 84

3.4. Cinética da atividade antibacteriana in vitro .................................................................. 86

3.5. Visualização da atividade antimicrobiana por MEV-FEG …………………………........ 86

3.6 Análise de estrutura tridimensional por espectroscopia de DC e RMN ........................... 87

3.7 Simulação in silico da interação com membrana DOPC......................................................91

Parte 4: Análise comparativa dos peptídeos desenhados .............................................. 93

4.1 Atividades antimicrobiana e citotóxica …………............................................................. 93

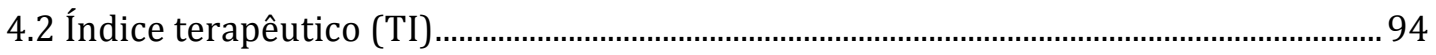

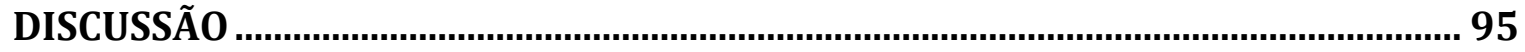

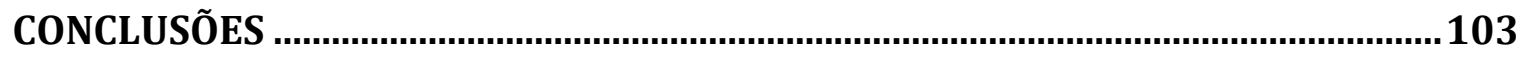

PERSPECTIVAS

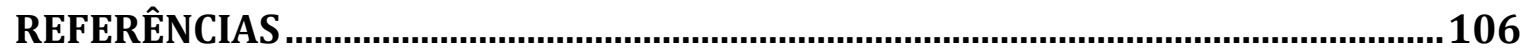




\section{INTRODUÇÃO}

\section{Doenças infecciosas nosocomiais}

Uma das maiores preocupações na área de saúde consiste na alta incidência de infecções microbianas que representam uma das principais causas de morte e incapacidade nos países em desenvolvimento. As doenças infecciosas podem ser causadas por microrganismos patogênicos, tais como bactérias, vírus, parasitas ou fungos, e podem ser transmitidas de forma direta ou indiretamente (por meio de veículos animados ou inanimados) de uma pessoa para outra. No caso particular das Infecções Relacionadas à Assistência à Saúde (IRAS), o principal agente causador de infecção são as bactérias, sendo estas associadas a 87\% das infecções (Anvisa, 2004). A Organização Mundial de Saúde (OMS) define as IRAS como infecções adquiridas durante o atendimento no hospital, infecções que, no ato da admissão do paciente, não estavam presentes ou em incubação (Who, 2011). As IRAS constituem uma importante causa de mortalidade e aumento dos custos hospitalares em países desenvolvidos. Além de causar graves infecções nosocomiais afetando pacientes hospitalizados, recentemente os microrganismos patogênicos vêm se espalhando na comunidade provocando doenças severas em pacientes previamente saudáveis.

Tanto as bactérias Gram-positivas (Gram+) quanto as Gram-negativas (Gram-) podem estar associadas em grande medida ao desenvolvimento das doenças infecciosas nosocomiais e comunitárias. As infecções causadas por fungos também têm seu papel nos quadros de infecção hospitalar, onde resultam ser responsáveis por aproximadamente $8 \%$ das IRAS, sendo Candida albicans e Aspergillus os patógenos mais frequentes (Anvisa, 2004). Muitos desses microrganismos constituem a microbiota humana normal. Devido a sua baixa virulência, as bactérias da microbiota possuem um papel protetor significativo, impedindo a colonização por microrganismos patogênicos. Entretanto, elas podem causar infecção em indivíduos imunocomprometidos ou debilitados, denominadas assim de 
bactérias oportunistas (Anvisa, 2004). Desta forma, as IRAS podem ser causadas por um microrganismo adquirido de outra pessoa no hospital (infecção cruzada) ou podem ser causadas pela flora do próprio paciente (infecção endógena). Geralmente, os sítios de infecção hospitalar mais frequentemente atingidos podem ser o trato urinário, as feridas cirúrgicas, o trato respiratório e o sangue. Os patógenos que lideram o ranking das IRAS estão descritos na Tabela 1.

Tabela 1. Agentes antimicrobianos e sítios de infecçõesmais frequentes nas doenças infecciosas nosocomiais (Anvisa, 2004).

\begin{tabular}{l|l}
\hline Patógeno & Sítios comuns de infecção \\
\hline Bactérias Gram negativas & \\
Escherichia coli & Trato urinário, feridas cirúrgicas, sangue \\
Pseudomonas $s p$ & Trato urinário, trato respiratório, queimaduras \\
Klebsiella $s p$ & Trato urinário, trato respiratório, feridas cirúrgicas \\
Enterobacter $s p$ & Trato urinário, trato respiratório \\
Bactérias Gram positivas & \\
Streptococcus sp & Trato urinário, trato respiratório, feridas cirúrgicas \\
Staphylococcus aureus & Pele, feridas cirúrgicas, sangue \\
Fungi & \\
Candida sp. & Trato urinário, sangue \\
\hline
\end{tabular}

\section{Composição das membranas biológicas}

As membranas biológicas funcionam como uma barreira celular de permeabilidade seletiva no transporte de moléculas para o interior e exterior da célula. A integridade das membranas celulares pode ser crucial na sobrevivência dos microrganismos, portanto, a ruptura da membrana resulta na morte celular. Praticamente todas as biomembranas são compostas de proteínas e fosfolipídeos, dispostos em bicamadas de característica anfipática tendo ambos os domínios, hidrofílico e hidrofóbico. As membranas dos organismos eucariontes e procariontes apresentam diferenças significativas em termos de composição, estrutura e carga. A superfície da membrana eucariótica pode ser rica em colesterol e fosfolipídios eletricamente neutros (zwitteriônicos), enquanto a superfície das 
células bacterianas apresenta densidade de carga negativa devido à presença de fosfolipídios eletricamente negativos na face externa da bicamada lipídica (Pasupuleti et al., 2012).

\section{Parede celular bacteriana}

As membranas bacterianas podem ser altamente complexas, apresentando diferenças estruturais que permitem a sua divisão em duas classes distintas de acordo com a sua resposta a coloração de Gram. As bactérias Gram-positivas apresentam composição singular na sua parede celular, baseada em mureína e peptidoglicanos, formando um arcabouço composto por uma alternância de $\mathrm{N}$-acetil-glicosamina e ácido Nacetilmurâmico, no qual se encontra ligado o ácido teicóico (Figura1A) (Kayser et al., 2005). Já as bactérias Gram-negativas são formadas por uma dupla camada membranácea, a qual consiste em uma membrana interna (MI) rica em fosfolipídios e uma externa (ME) rica em fosfolipídios e lipopolissacarídeos (LPS). O espaço periplasmático que separa essas membranas contém peptidoglicanos (Figura1B). Vários grupos de proteínas podem estar associados a essas membranas e envolvidas em diferentes atividades como ligação a ATP, transporte de íons e de pequenas moléculas. Dentre essas proteínas observam-se as porinas e lipoproteínas, associadas a ME; as proteínas integrais, que atravessam a ME em várias regiões; as periplasmáticas e as associadas à MI (Cordwell, 2006). As bactérias Gram-negativas produzem uma variedade de polissacarídeos, como o LPS e os polissacarídeos capsulares, que podem ser particularmente importantes para a sua interação com o sistema imunitário do hospedeiro. O LPS atua como uma molécula padrão associada ao patógeno, estimulando a resposta do hospedeiro, e os polissacarídeos capsulares podem formar barreiras físicas (biofilmes e estruturas capsulares), as quais favorecem a evasão da resposta imune do hospedeiro (Pasupuleti et al., 2012). 


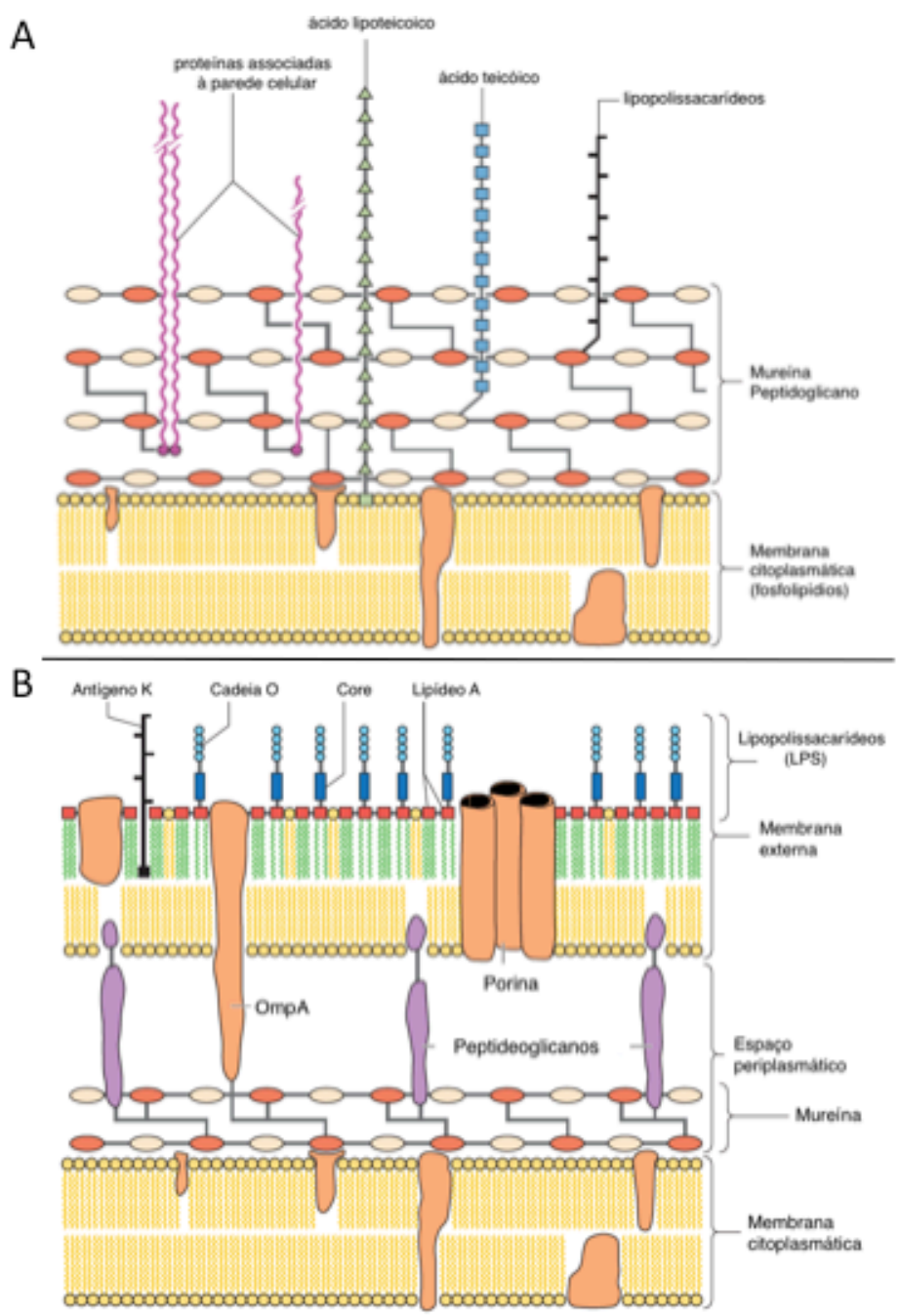

Figura 1. Parede celular de bactérias (A) Gram-positivas e (B) Gram-negativas (Kayser et al., 2005).

\section{Parede celular fúngica}

Os fungos são dotados de uma parede celular que possui estrutura dinâmica e robusta mantendo a forma das células e mediando a comunicação entre estas e o meio ambiente. A parede celular fúngica atua como uma barreira que protege as células das mudanças no ambiente extracelular, evitando danos físicos e osmóticos. No caso dos fungos patógenos, as diferenças moleculares entre as superfícies das células humanas e fúngicas permitem que sejam reconhecidos pelo sistema imune inato do hospedeiro infetado. A composição da parede celular dos fungos possibilita a distinção de duas camadas principais sendo uma camada exterior, composta de glicoproteínas (polímeros de 
manose, covalentemente associados com proteínas) e uma camada interna que contém uma estrutura esquelética de polissacarídeos quitina e $\beta$-1,3-glucano que conferem resistência à célula. As proteínas da camada externa podem estar ligadas à camada interna, predominantemente por glicosilfosfatidilinositol (GPI) associados através de moléculas $\beta$-1,6-glucano, de caráter mais flexível (Figura 2). As proteínas e os lipídeos estão presentes em menor proporção e os polímeros estruturais, $\beta$-glucano e quitina, conferem rigidez à parede celular. Os polímeros de manose constituem uma matriz amorfa na qual podem ser inseridos os polímeros estruturais (Gow et al., 2012). Em virtude da importância vital da superfície celular dos microrganismos, muitos antibióticos comumente utilizados atuam interferindo com a estabilidade dessa estrutura.
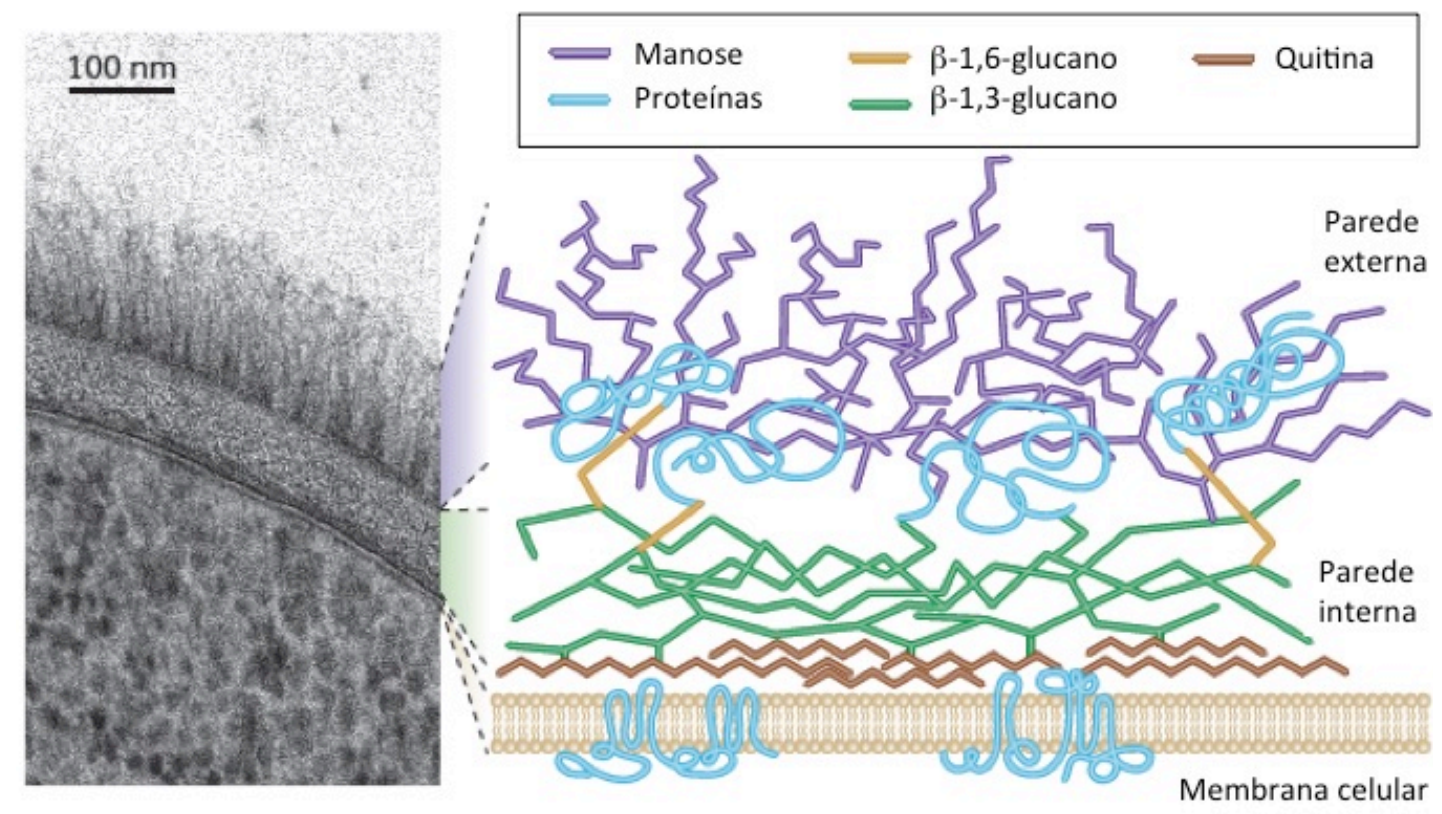

Figura 2. Estrutura de parede celular do fungo Candida albicans (Gow et al., 2012).

À semelhança das bactérias, uma característica importante para a sobrevivência dos fungos (especialmente C. albicans), consiste no desenvolvimento de biofilmes quando expostos às superfícies sólidas. Isto constitui um grande problema na prática médica, pois os biofilmes podem estabelecer-se na superfície de diversos implantes médicos invasivos 
como é o caso dos cateteres intravenosos, os quais podem promover o acesso direto do patógeno na corrente sanguínea do paciente.

\section{Antimicrobianos utilizados no tratamento das infecções e mecanismos de resistência}

Para o tratamento de doenças infecciosas existe a necessidade do uso de agentes capazes de eliminar o patógeno (microbicidas) ou de interromper a sua proliferação. Desde a década de 1940, quando a penicilina se tornou disponível para uso, se deu início a uma nova fase da medicina conhecida como a fase dos antimicrobianos. Desde então, muitas moléculas de origem natural têm sido identificadas e outras sintetizadas, reduzindo muito a doença e a morte por infeção. De forma geral, os antimicrobianos podem ser divididos em diferentes classes e apresentam diversos mecanismos de ação capazes de modificar o metabolismo microbiano e processos fisiológicos como a tradução, replicação de DNA e biossíntese da parede celular. Frequentemente, os agentes antimicrobianos podem ser classificados de acordo com o seu principal mecanismo de ação. Entre esses mecanismos encontram-se a interferência com a síntese da parede celular ( $\beta$-lactâmicos e agentes glicopeptídicos), a inibição da síntese proteica (macrólidos e tetraciclinas), a interferência com a síntese de ácidos nucleicos (fluoroquinolonas e rifampicina), a inibição de uma via metabólica (trimetoprim-sulfametoxazol), e a perturbação da estrutura da membrana bacteriana (polimixinas e daptomicina) (Tabela 2) (Tenover, 2006). 
Tabela 2. Mecanismos de ação dos agentes antimicrobianos (Tenover, 2006).

\begin{tabular}{|c|c|}
\hline Mecanismo de ação & Antibiótico \\
\hline $\begin{array}{l}\text { INIBIDORES DA SÍNTESE } \\
\text { DA PAREDE CELULAR }\end{array}$ & $\begin{array}{l}\beta \text {-lactâmicos: penicilina, carbapenemos, cefalosporinas } \\
\text { Glicopeptídeos: vancomicina, teicoplanina }\end{array}$ \\
\hline $\begin{array}{l}\text { INIBIDORES DA SINTESE } \\
\text { PROTEICA }\end{array}$ & $\begin{array}{l}\text { Ligação à subunidade ribossomal 50S: macrolídeos, } \\
\text { cloranfenicol, clindamicina } \\
\text { Ligação à subunidade ribossomal 30S: } \\
\text { aminoglicosídeos, tetraciclina }\end{array}$ \\
\hline $\begin{array}{l}\text { INIBIDORES DA SINTESE DE } \\
\text { ACIDOS NUCLEICOS }\end{array}$ & $\begin{array}{l}\text { Inibição da síntese de DNA: fluoroquinolonas } \\
\text { Inibição da síntese de DNA: rifampicina }\end{array}$ \\
\hline $\begin{array}{l}\text { INIBIDORES COMPETITIVOS DA } \\
\text { SINTESE DE METABOLITOS } \\
\text { ESSENCIAIS }\end{array}$ & Sulfonamidas, análogos do ácido fólico \\
\hline $\begin{array}{l}\text { DANO A MEMBRANA } \\
\text { PLASMATICA }\end{array}$ & Polimixinas e daptomicina \\
\hline
\end{tabular}

A utilização indiscriminada de antibióticos e drogas afins para terapia ou profilaxia, pode aumentar a pressão de seleção que favorece o surgimento, multiplicação e disseminação de cepas resistentes. A resistência antimicrobiana pode ser parte de um processo natural de evolução, no qual os microrganismos desenvolvem mecanismos de adaptação e sobrevivência ao ambiente em que vivem. Os microrganismos resistentes podem sobreviver à exposição as drogas e continuam a sua multiplicação no corpo, causando mais danos e aumentando a capacidade de transmissão (Rice, 2009). A propagação da resistência antimicrobiana pode ser ainda mais exacerbada pelo aumento do comércio e das viagens internacionais, tornando mais fácil para formas resistentes de uma doença, se espalhar entre países e continentes. As infecções por microrganismos resistentes são difíceis de tratar, exigindo alternativas terapêuticas de custo elevado e às vezes tóxicas.

As bactérias podem ser intrinsecamente resistentes a uma classe de agentes antimicrobianos, ou podem adquirir resistência por mutação ou através da aquisição de genes de resistência de outros organismos. Esses genes de resistência podem permitir o bloqueio da entrada da droga na célula, a produção de enzimas proteolíticas que destroem a droga antibacteriana, a expressão de sistemas de efluxo que impedem a droga de 
penetrar na célula e atingir o seu alvo intracelular, a alteração nos sítios alvo do medicamento, ou a produção de vias metabólicas alternativas que evitem a ação da droga (Tenover, 2006; Alekshun e Levy, 2007; Allen et al., 2010) (Figura 3).

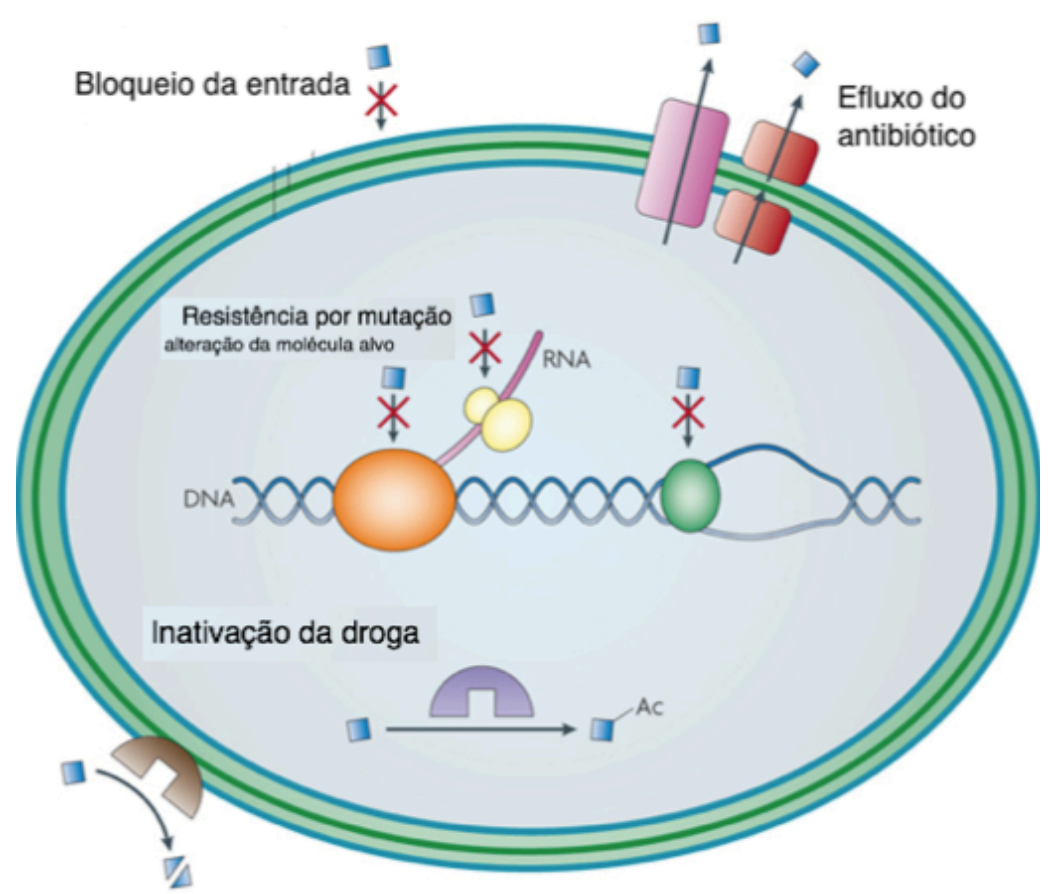

Figura 3. Mecanismos de resistência bacteriana aos agentes antimicrobianos. Adaptado de (Allen et al., 2010).

Em populações bacterianas, constantemente ocorrem mutações devido a erros durante a replicação. Se houver alguma vantagem seletiva de alguma mutação, como por exemplo a resistência a antibiótico, o mutante se torna rapidamente o principal componente da população devido à elevada taxa de crescimento da bactéria, o que pode constituir um problema no tratamento das infecções bacterianas. Não apenas as mutações podem ser um problema, como também os mecanismos pelos quais as bactérias transferem seus genes para outras células. Genes bacterianos são normalmente transferidos a membros da mesma espécie, mas ocasionalmente a transferência para outras espécies pode também ocorrer (Kayser et al., 2005). 
A transferência de novo material genético entre as cepas resistentes e as cepas bacterianas suscetíveis aos antimicrobianos, pode ocorrer por meio de mecanismos como a transformação (o material genético liberado ao meio pela célula doadora, pode ser tomado pela célula receptora), a conjugação (transferência gênica unidirecional por contato físico entre as células), ou a transdução (transferência gênica pela via de um bacteriófago). Frequentemente os elementos de transposição (segmentos de DNA que possuem a capacidade de se movimentar de uma região para outra do genoma), podem facilitar a incorporação de genes de resistência múltipla diretamente no genoma do receptor ou nos plasmídeos (Alekshun e Levy, 2007).

\section{O cenário atual da resistência bacteriana}

Nas últimas décadas, uma grande variedade de bactérias patogênicas resistentes à drogas tem se multiplicado e disseminado a taxas alarmantes (Brown e Wright, 2016). As bactérias mostram uma excelente habilidade em resistir e se adaptar ao ambiente através da seleção e troca de elementos genéticos de resistência. Assim como nos estabelecimentos de cuidados em saúde como na comunidade, a resistência antimicrobiana pode ser um problema, porém nos hospitais a transmissão pode ser amplificada por causa da população altamente suscetível e do grande reservatório de patógenos virulentos e oportunistas que representa o ambiente hospitalar. O impacto clínico da resistência antimicrobiana pode ser insignificante ou grave, dependendo do nível de resistência, do local da infecção, e da disponibilidade de alternativas terapêuticas eficazes (Rice, 2009). O aumento da prevalência da resistência antimicrobiana pode representar uma preocupação global. O Brasil e outros países da América Latina, em geral, podem ter níveis mais elevados de resistência bacteriana entre os principais patógenos, comparados com a Europa e os Estados Unidos (Reinert et al., 2007). 
Nas últimas décadas, tem sido relatado um aumento significativo de infecções causadas por patógenos resistentes, incluindo Staphylococcus aureus resistentes à meticilina (MRSA, do inglês methicillin-resistant S. aureus); Enterococcus spp. resistentes à vancomicina (VRE, do inglês vancomicin-resistant Enterococcus spp.); bactérias produtoras de enzimas capazes de hidrolisar antibióticos carbapenêmicos tais como Klebsiella pneumoniae (KPC) e Pseudomonas aeruginosa; K. pneumoniae e Escherichia coli ß-lactamases de espectro estendido (ESBLs, do inglês extended-spectrum beta-lactamases) e Acinetobacter spp. resistente a múltiplas drogas (MDR, do inglês multiple drug resistant) observadas particularmente nas IRAS (Ventola, 2015). Especificamente no Brasil, as cepas que apresentam uma maior prevalência são $S$. aureus MRSA, K. pneumoniae e E. coli ESBLs, com prevalências de 60, 50 e 18\%, respectivamente (Rossi, 2011).

Ao longo dos anos, a pressão seletiva do uso de diferentes drogas resultou em microrganismos portadores de mecanismos de resistência a múltiplas drogas. Embora o surgimento de microrganismos MDR seja um fenômeno natural, o uso inadequado e descontrolado de agentes antimicrobianos, incluindo a prescrição desnecessária, a administração de doses inadequadas, o tempo insuficiente de tratamento e os erros de diagnóstico que levam à escolha inadequada de medicamentos, amplificam o fenômeno (Ventola, 2015). Como consequência, um aumento de ganho de resistência pela vasta maioria de agentes patogênicos humanos foi relatado em todo o mundo (Huttner et al., 2013). Atualmente a resistência antimicrobiana compreende uma ameaça global que expõe sérios desafios clínicos onde as drogas comumente utilizadas se tornaram um recurso não renovável que pode ser extinto (Brown e Wright, 2016). 


\section{Peptídeos antimicrobianos (AMPs): uma nova fronteira no controle da infecção microbiana}

Apesar do esforço realizado desde o tempo da penicilina pelas indústrias farmacêuticas na elaboração de metodologias para a busca e desenvolvimento de novos agentes antimicrobianos, a prospecção de novos compostos continua sendo limitada. As empresas farmacêuticas parecem ter retirado os esforços na produção de novos agentes antimicrobianos, uma vez que apenas duas novas classes de antibióticos chegaram ao mercado desde 1962: a oxazolidinona (linezolida por Pfizer) e um lipopéptido cíclico (daptomicina por Cubist) (Coates et al., 2011), ativas contra bactérias Gram-positivas, incluindo MRSA.

Progressivamente, mais patógenos desenvolvem resistência contra os antibióticos convencionais, tornando assim indispensável à busca por novas substâncias potencialmente bioativas (Harbarth et al., 2015). Dentre essas novas moléculas, os peptídeos antimicrobianos (AMPs) se destacam como uma nova ferramenta biotecnológica na busca de antimicrobianos de caráter inovador (Silva et al., 2011; Da Costa et al., 2015; Fosgerau e Hoffmann, 2015).

Comumente encontrados na natureza, os AMPs podem ser efetores do sistema imune inato de qualquer organismo. Este grupo de moléculas representa um mecanismo primitivo de defesa imunitária presente em diferentes organismos multicelulares tais como plantas, insetos, peixes, mamíferos e anfíbios (Zasloff, 2002; Pasupuleti et al., 2012). A ampla distribuição dos AMPs nos reinos animal e vegetal, sugere um papel fundamental na evolução bem-sucedida de organismos multicelulares complexos. Devido ao efeito bactericida, fungicida, antiviral e antitumoral dos AMPs, aliado ao fato de atuarem a baixas concentrações, eles podem ser considerados candidatos promissores a 
agentes terapêuticos no tratamento de infecções, em especial em situações de resistência à antibioterapia clássica (Afacan et al., 2012).

As vantagens potenciais dos AMPs como medicamentos antimicrobianos e imunomoduladores são significativas (Yount e Yeaman, 2005; Hancock e Sahl, 2006; Upton et al., 2012). Os AMPs possuem a habilidade de eliminar um grande espectro de microrganismos de forma rápida, incluindo bactérias multirresistentes. Muitos AMPs têm demonstrado a capacidade de ativar a resposta imune inata sem exibir imunogenicidade. Estes peptídeos, ainda, têm uma ampla gama de propriedades imunomoduladoras, incluindo a regulação da expressão de centenas de genes em variedade de células imunitárias e a indução de produção de citocinas (Finlay e Hancock, 2004; Bowdish et al., 2005; Oppenheim e Yang, 2005). Alguns AMPs mostraram um efeito sinérgico com antibióticos convencionais, aumentando a sua potência in vivo, provavelmente facilitando seu acesso na célula bacteriana (Park et al., 2011). Outros AMPs podem ser utilizados também no controle de infecções sistêmicas, já que demonstraram reduzir o dano no tecido provocado pela resposta inflamatória à infecção, enquanto estimularam, simultaneamente, a atividade antimicrobiana do sistema imune (Upton et al., 2012). Outras aplicações incluem a utilização destas moléculas para impedir a colonização e o crescimento de microrganismos em materiais poliméricos sintéticos, tais como cateteres intravenosos de uso médico (Melvin et al., 2016).

Os AMPs são pequenos polipeptídeos de baixa massa molecular (menor do que 5 kDa) em sua maioria catiônicos, de sequências e estruturas variáveis (Reddy et al., 2004). Apesar da sua grande diversidade, os AMPs são conhecidos por terem uma estrutura secundária anfipática com conjuntos de regiões hidrofóbicas e carregadas positivamente, com resíduos de aminoácidos arranjados de forma linear ou cíclica. Essa propriedade 
estrutural aparece como estando intimamente relacionada à sua atividade antimicrobiana (Hancock e Sahl, 2006).

Até o momento, mais de 2500 AMPs com propriedades bactericida, fungicida, virucida e antitumoral, foram descobertos ou sintetizados (http://aps.unmc.edu/AP/main.php; Antimicrobial Peptide Database) e têm sido agrupados com base no comprimento, na estrutura secundária e terciária, na presença ou ausência de ligações dissulfeto. De acordo com a classificação proposta por Hancock (2003), os AMPs podem ser organizados com base na estrutura tridimensional dentro de 4 classes incluindo folhas- $\beta$, $\alpha$-hélices, loops ou peptídeos estendidos e mista, com as duas primeiras classes encontradas com maior frequência na natureza (Figura 4) (Powers e Hancock, 2003). A estrutura de folha- $\beta$ encontra-se estabilizada pela presença de 2 ou 3 ligações dissulfeto e, ocasionalmente, apresenta pequenas porções de estrutura $\alpha$-hélice. As estruturas helicoidais e estendidas, ocorrem apenas quando o peptídeo entra em contato com a membrana, apresentando uma conformação randômica em soluções aquosas (Yeaman e Yount, 2003). 
(A)

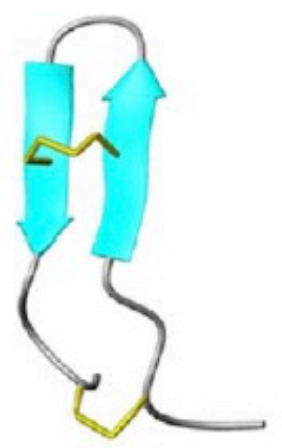

(B)

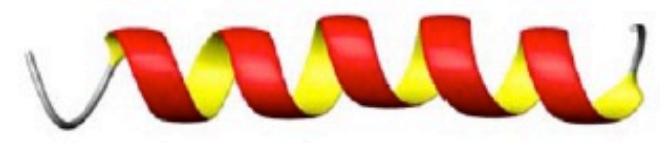

(C)

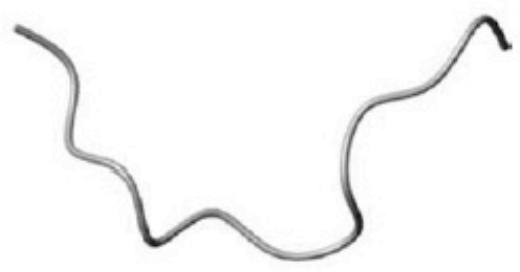

(D)

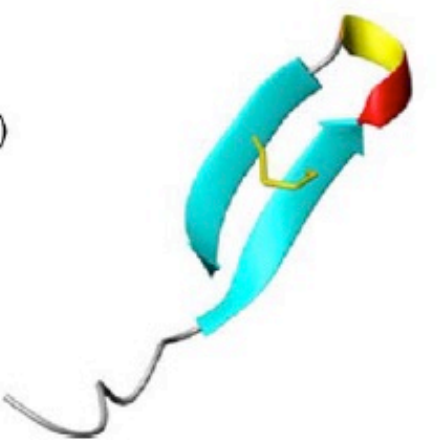

Figura 4. Representação das classes estruturais de AMPs. (A) folha- $\beta$, taquiplesina I; (B) $\alpha$ hélice, magainina II; (C) estendida, indolicidina; (D) mista, thanatina. As ligações dissulfeto estão indicadas em amarelo (Powers e Hancock, 2003).

\section{Atividade e seletividade dos AMPs}

O mecanismo de ação dos AMPs vem sendo estudado ativamente e ainda hoje as informações disponíveis nas publicações científicas, continuam crescendo. De forma geral, o potencial terapêutico dos AMPs pode ser associado com sua interação às membranas biológicas promovendo a sua desestabilização e, como consequência, vazamento de conteúdo intracelular destruindo rapidamente um amplo espectro de microrganismos (Huang et al., 2010). Acredita-se que a natureza anfipática (separação espacial entre uma porção hidrofóbica e outra hidrofílica) e o caráter catiônico (alta frequência de aminoácidos básicos como a arginina e/ou lisina) dos AMPs contribuem no desempenho da interação com a superfície da célula-alvo e a sua inserção na membrana. Portanto, a seletividade dos AMPs tem base nas diferentes composições lipídicas e as cargas presentes nas membranas de células eucarióticas e procarióticas. A camada externa da membrana celular de mamíferos e organismos eucariontes em geral, pode ser composta 
por lipídeos neutros que dificultam a interação eletrostática com os AMPs, protegendo-a assim da sua ação (Yeaman e Yount, 2003). Porém, as interações eletrostáticas entre os AMPs e as superfícies das células bacterianas, podem ser facilitadas pela presença de fosfolipídios carregados negativamente na face externa da bicamada lipídica.

Contrário aos antibióticos de uso convencional, o efeito letal dos AMPs pode ser independente do reconhecimento de receptores. Como consequência, por muito tempo acreditou-se que os AMPs eram menos propensos a induzir mecanismos de resistência do que os antibióticos convencionais. Atualmente, é suposto que o desenvolvimento de resistência aos AMPs surge a partir de mutações espontâneas assim como também há exemplos de bactérias com resistência intrínseca a determinados AMPs (Maria-Neto et al., 2012). Os mecanismos de resistência aos AMPs podem ser extremamente complexos e, pelo menos até agora, não parecem seguir um padrão único. Dentre os principais mecanismos de resistência destacam-se o sequestro de peptídeos; a destruição por proteólise através da expressão de proteases extracelulares; a remoção por meio de transporte ativo; a modificação no metabolismo energético; e a alteração estrutural e/ou de carga da superfície bacteriana para evitar a interação com os AMPs (Nizet, 2006; Peschel e Sahl, 2006).

Embora a resistência aos AMPs parece ser menos comum do que a resistência aos antibióticos convencionais, a co-evolução dos agentes patogênicos e seus hospedeiros possibilitou a seleção desta característica em várias bactérias. Uma melhor compreensão dos mecanismos de resistência revela-se fundamental para a concepção de AMPs otimizados que permitam ser eficientemente utilizados como drogas terapêuticas (Guilhelmelli et al., 2013). 


\section{Mecanismo de ação dos AMPs}

A ação microbicida associada aos AMPs pode ocorrer de maneira muito rápida, desafiando a caracterização passo a passo. Porém, de acordo com Brogden, o mecanismo antibacteriano dos AMPs depende de 3 passos específicos para a indução da lise bacteriana, descritos a seguir (Brogden, 2005).

A primeira etapa compreende a atração dos AMPs pela superfície bacteriana. Acredita-se que devido a sua característica catiônica, os AMPs podem ser capazes de estabelecer interações eletrostáticas com a membrana bacteriana, composta em grande parte por fosfolipídios carregados negativamente. Porém, as membranas das bactérias Gram-negativas e positivas, revelam-se muito mais complexas do que as membranas modelo, e os AMPs catiônicos seriam propensos a ser atraídos primeiramente pela carga negativa da membrana externa de bactérias Gram-negativas (por exemplo, pelos fosfolipídios aniônicos e os grupos fosfato nos lipopolissacarídeos) assim como pelos ácidos teicóicos na superfície de bactérias Gram-positivas (Powers e Hancock, 2003).

A segunda etapa refere-se à ligação, na qual os AMPs devem atravessar os polissacarídeos capsulares até conseguir acessar à membrana citoplasmática das bactérias para poder interagir com os lipídeos da bicamada. Esse acontecimento parece ser de grande importância porém, varias vezes desconsidera-se nos estudos de mecanismo de ação.

Finalmente, ocorre a inserção e permeabilização. A anfipaticidade dos AMPs facilitaria a sua inserção na membrana através da interação de sua região hidrofóbica com a região hidrofóbica dos fosfolipídios de membrana. Quando a relação peptídeo/lipídeo é baixa, os AMPs se alinham paralelamente a bicamada lipídica. A medida que essa relação aumenta, os AMPs começariam a se orientar perpendicularmente até inserção na 
bicamada, podendo ou não romper a membrana, sendo esse o ponto que distingue o seu mecanismo de ação (Brogden, 2005).

A característica peculiar dos AMPs de provocar a morte celular a partir da lise da membrana levou ao estudo profundo do mecanismo de ação dos AMPs. Com base nos resultados experimentais de vários estudos realizados com peptídeos $\alpha$-hélices catiônicos e anfipáticos, foram propostos três modelos para explicar como esses AMPs rompem a membrana plasmática microbiana (Huang et al., 2010):

Modelo carpete: os peptídeos não são inseridos na membrana, mas são alinhados paralelamente a bicamada lipídica permanecendo em contato com o grupo cabeça dos lipídeos formando um tapete sobre a membrana. Em concentrações elevadas, os peptídeos orientados sobre a superfície são pensados interromper a bicamada de uma forma detergente (detergent like), levando a formação de micelas (Figura 5). Com uma concentração limiar crítica, os peptídeos podem formar buracos transientes na membrana permitindo peptídeos adicionais acessarem a membrana. Essa orientação levaria a uma perturbação local na estabilidade da membrana, promovendo a formação de grandes fissuras, vazamento de componentes citoplasmáticos, perturbação do potencial da membrana e finalmente desintegração da membrana.

Modelo barril: os peptídeos anfipáticos agregam-se e reorientam-se de modo que a face catiônica fica virada para os grupos fosfatos presentes na superfície da bicamada lipídica. Ao atingir uma determinada concentração, os peptídeos inserem-se perpendicularmente na bicamada lipídica, mantendo as regiões hidrofóbicas ligadas à região apolar da membrana enquanto as regiões hidrofílicas ficam expostas, formando grandes poros transmembranares. Esses poros facilitam o fluxo livre de íons e moléculas pequenas, permitindo a fuga de componente citoplasmático e também a ruptura da membrana (Figura 5). 
Modelo poro toroidal: o peptídeo anfipático interage eletrostaticamente com a membrana plasmática fosfolipídica e se une paralelamente a mesma. Dessa forma o peptídeo separa as cabeças polares dos fosfolipídios e induz a monocamada lipídica a se dobrar formando um poro toroidal. Nesse poro os peptídeos inseridos e os grupos das cabeças polares dos lipídeos interagem e se alinham ao núcleo aquoso. Esses poros atuam como canais não seletivos a íons, toxinas e metabolitos impedindo assim a bactéria manter a sua homeostase vital (Figura 5). Este modelo tem sido utilizado para explicar a formação de poros nas membranas induzidos pelos peptídeos magainina, protegrina e melittina.

Durante muito tempo acreditou-se que o efeito membranolítico dos AMPs provavelmente determinava sua atividade antimicrobiana. Porém, os contínuos estudos revelaram que a sua função poderia ser mais complexa do que o inicialmente esperado. Os AMPs podem apresentar diferentes mecanismos de ação, inclusive a combinação de mais de uma estratégia na destruição dos patógenos. Assim, um processo pode representar o passo inicial ou, o intermediário de outro. Além disso, o mecanismo final dependerá do balanço entre as propriedades do peptídeo e a composição da membrana do patógeno alvo (Papo e Shai, 2003).

A Figura 5 ilustra os diferentes modelos de interação pelos quais os AMPs alteram a organização da membrana bacteriana causando a perda do equilíbrio osmótico. A espessura da bicamada pode ser afetada pela presença de peptídeos. Também, a membrana pode se remodelar de modo a formar domínios ricos em lipídeos aniônicos em volta desses peptídeos. Em casos mais específicos, pode ocorrer a formação de intermediários "non-bilayer"; a oxidação dos fosfolipídios; ou a ligação dos AMPs a pequenos ânions através da bicamada, resultando no seu efluxo. O potencial de membrana pode ser alterado sem necessariamente provocar danos visíveis, ou segundo o modelo de 
eletroporação molecular, a acumulação de peptídeos na monocamada externa pode induzir o aumento do potencial de membrana o que torna a membrana permeável transitoriamente a várias moléculas, incluindo os próprios peptídeos (Nguyen et al., 2011).

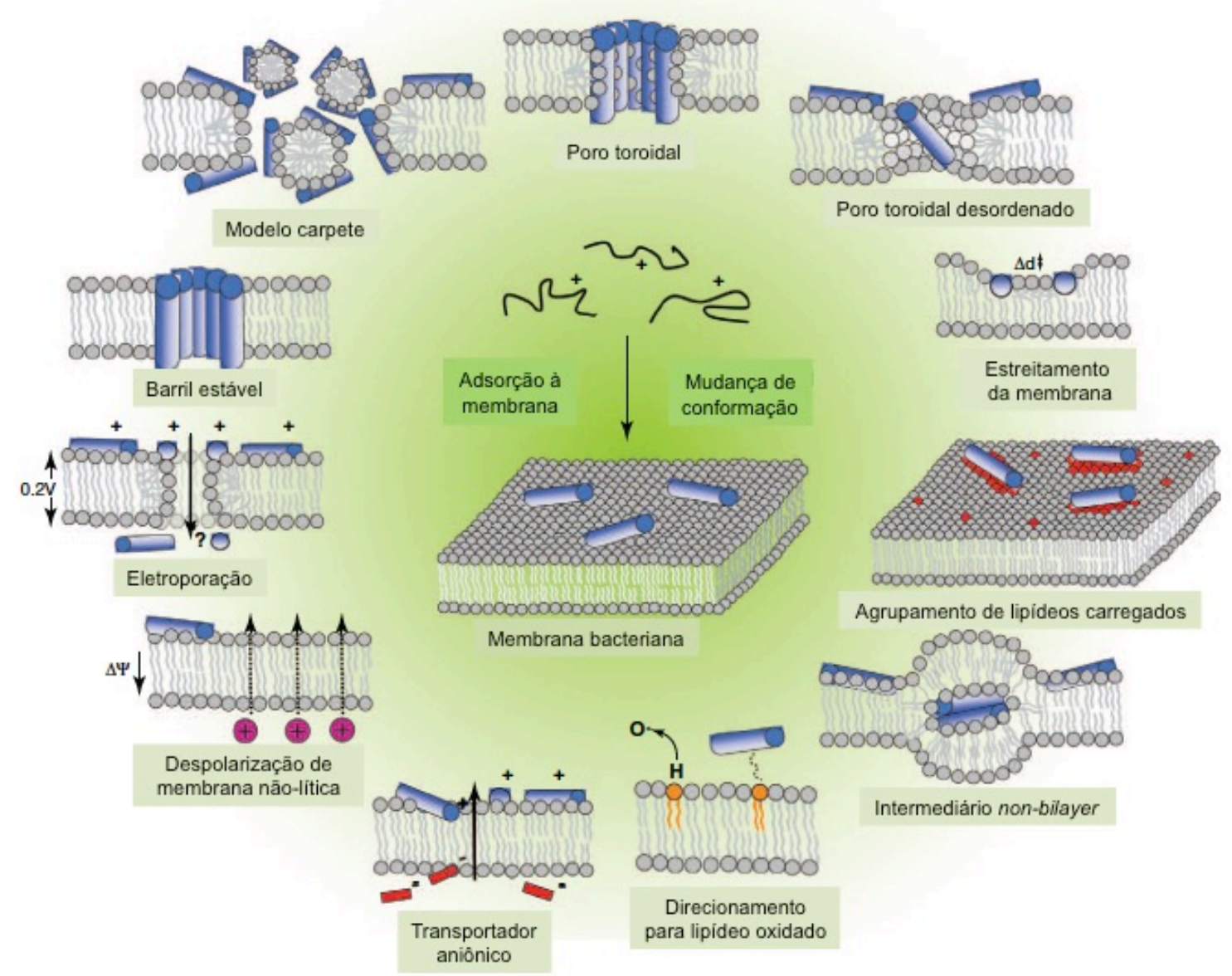

Figura 5. Modelos de interação entre os AMPs e a membrana bacteriana. Adaptado de Nguyen et al., 2011.

Segundo diversos estudos, a formação de poros transmembrana parece não ser o único mecanismo de ação antimicrobiana. Alguns AMPs têm como principal alvo a bicamada das membranas das células atacadas, enquanto outros atravessam a membrana e podem causar lise celular por meio da ativação de estruturas intracelulares. Várias observações sugerem que os peptídeos inibem a síntese de DNA, RNA e proteínas, 
inibem a atividade enzimática, ativam autolisinas e interferem na formação da parede celular (Brogden, 2005; Mookherjee e Hancock, 2007; Nicolas, 2009).

Recentemente, tem sido proposto por Lee e colaboradores, um mecanismo de ação detalhado no qual foram exploradas as mudanças na estrutura da membrana alvo durante a ligação dos AMPs. Este trabalho propõe um modelo de plasticidade de membrana onde a partir da interação inicial do peptídeo com seu alvo de membrana, ocorrem mudanças de conformação e diferentes estados intermédios da membrana que surgem na presença de quantidades crescentes do peptídeo ligado, sendo a prevalência de cada estado dependente do peptídeo e da composição da membrana (Lee et al., 2016).

Os mecanismos de ação dos AMPs parecem estar relacionados aos efeitos hidrofóbicos e eletrostáticos combinados (Dathe et al., 2002). Porém, ao definir a atividade antimicrobiana, além das características físico-químicas dos AMPs, pode ser fundamental ter em consideração as condições fisiológicas in vivo. Isto inclui as concentrações de AMPs no local da infecção, o papel de substâncias sinérgicas e inibidoras que podem estar presentes em tecidos e fluidos, assim como determinadas características únicas de replicação bacteriana, particularmente a formação de biofilmes (Fox, 2013; Melvin et al., 2016).

\section{Determinantes estruturais dos AMPs para a atividade antimicrobiana}

Como apresentado anteriormente, a ação antimicrobiana dos AMPs pode ocorrer pela combinação de efeitos hidrofóbicos e eletrostáticos que levam a perturbações na membrana das células alvo. Apesar de quase duas décadas de esforços, a falta de conhecimento detalhado dos complexos métodos de ação dos AMPs, continua limitando a compreensão das relações estrutura-atividade, e como consequência, geram restrições no 
aproveitamento de dados e no desenvolvimento de terapias antimicrobianas sobre a base de peptídeos (Fosgerau e Hoffmann, 2015).

Além de exibirem uma grande variedade estrutural e de sequência, as propriedades físico-químicas dos AMPs podem ou não estar associadas a seu mecanismo de ação, a sua efetividade e especificidade de interação com membranas fosfolipídicas (Powers e Hancock, 2003). As diferenças eletrostáticas na composição das membranas plasmáticas de mamíferos e bactérias, parecem ser as responsáveis pela toxicidade seletiva dos AMPs. No entanto, além de atrair os AMPs catiônicos, as superfícies aniônicas das membranas bacterianas podem influenciar outros processos que afetam a seletividade (Khandelia e Kaznessis, 2006). Sabe-se que a maioria dos AMPs carecem de estrutura definida em solução, adotando uma forma geralmente helicoidal, após ligação à membrana. Portanto, o grau de formação de hélice induzida na presença da membrana, pode influenciar a atividade hemolítica e as propriedades antibacterianas dos AMPs (Dathe et al., 1996). A atividade antimicrobiana pode ser induzida, então, pela interação com a membrana da célula alvo.

Compreender as relações entre as principais características estruturais dos AMPs e seus efeitos sobre a atividade bactericida e hemolítica, pode auxiliar o desenho racional de análogos melhorados para uso clínico (Nguyen et al., 2011). Vários estudos têm sido realizados sobre a relação estrutura-função dos AMPs através da modulação de parâmetros estruturais tais como carga, conformação, hidrofobicidade, momento hidrofóbico, anfipaticidade, e ângulo polar (Wimley, 2010). Por meio desses estudos, constatou-se que tais propriedades determinam a potência e o espectro de atividade antimicrobiana, porém atuando de maneira interdependente. A modificação em um parâmetro induz alterações simultâneas em outros, o que torna difícil avaliar a influência específica de uma única variável (Yeaman e Yount, 2003). 
Os AMPs podem ser caracterizados por apresentarem carga líquida positiva, variando entre +2 e +9 . Esta cationicidade ocorre devido à ausência de resíduos ácidos (ácidos glutâmico e aspártico) e a presença em excesso de resíduos de aminoácidos básicos tais como arginina, lisina e histidina (Brown e Hancock, 2006). O caráter catiônico, de grande importância para a interação eletrostática dos AMPs com as membranas biológicas, pode garantir uma certa seletividade na atividade antimicrobiana. Os AMPs manifestam uma baixa atração pelas membranas citoplasmáticas de células de mamíferos de caráter eletricamente neutro, e uma alta afinidade pela superfície eletricamente negativa da superfície das células microbianas. Vários estudos mostraram que a atividade dos AMPs pode depender do seu caráter catiônico, relacionando mudanças na carga líquida com um aumento ou diminuição da efetividade antimicrobiana. No caso do peptídeo dermaseptina S4, por exemplo, um aumento da carga positiva, pode reduzir sua atividade hemolítica sem modificar sua ação antiviral (Lorin et al., 2005). No entanto, a adição de carga positiva apresenta um limite, como demonstrado para a magainina II, no qual, um excesso de cationicidade pode levar ao incremento da capacidade hemolítica e perda de atividade antimicrobiana (Dathe et al., 2001).

A detalhada informação da estrutura e a orientação dos AMPs pode ser um elemento importante para a compreensão do papel dos aminoácidos individuais na formação de oligómeros em solução ou em ambientes que mimetizam as condições de membranas biológicas, assim como para uma melhor compreensão do mecanismo da lise celular. Portanto, a caracterização da estrutura tridimensional dos AMPs e suas interações dinâmicas com os lipídeos da membrana são elementos chave na compreensão das atividades biológicas. Para atingir esse objetivo, duas técnicas de espectroscopia são comumente utilizadas. O dicroísmo circular (DC), que fornece informações sobre as condições experimentais em que ocorre uma mudança estrutural, e a ressonância 
magnética nuclear (RMN), de maior resolução, que permite obter informações sobre as interações peptídeo-membrana em nível atômico. Ambas técnicas de espectroscopia permitiram determinar que os AMPs sofrem uma transição na conformação em presença de solventes orgânicos que mimetizam o ambiente de membrana celular tais como o TFE (trifluoretanol), o SDS (dodecil sulfato de sódio) ou em contato com modelos de membrana mais complexos, tais como vesículas de fosfolipídeos e lipossomas. Em um ambiente aquoso, os peptídeos lineares apresentam conformação randômica, ou seja, não evidenciam elementos de estrutura secundária. Logo, durante a interação do peptídeo com a superfície externa de diferentes tipos de membrana (aniônicas, zwitteriônicas) pode ocorrer uma mudança de conformação. Geralmente, os modelos de membranas microbianas induzem a formação de estruturas helicoidais ( $\alpha$-hélice ou folha- $\beta$ ). É preciso ressaltar que as modificações estruturais dos AMPs dependem tanto da composição lipídica da membrana, como também da temperatura, $\mathrm{pH}$ e força iónica (Blondelle et al., 1999).

Acredita-se que a estrutura secundária adotada pelos AMPs em presença da membrana alvo tem influência significativa na sua atividade e seletividade. De fato, a indução de uma conformação em particular demonstrou ser um requerimento para a atividade lítica dos AMPs (Dathe e Wieprecht, 1999). Além disso, o modo de inserção na membrana provavelmente depende da conformação adotada.

De forma geral, os AMPs apresentam uma estrutura anfipática na interação com membranas biológicas. A anfipaticidade, caracterizada pela separação de uma face hidrofóbica e de uma hidrofílica, ocorre em uma grande variedade de estruturas sendo a estrutura helicoidal a mais comum entre os AMPs lineares. O caráter anfipático nos peptídeos de conformação $\alpha$-hélice, pode ser formado com uma sequência periódica de resíduos polares e apolares em um intervalo entre três a quatro resíduos de aminoácidos. 
Dessa forma, as cadeias laterais polares e apolares dos resíduos de aminoácidos posicionam-se adequadamente para uma separação em faces opostas (Huang et al., 2010).

A anfipaticidade reflete a abundância relativa e a polarização dos domínios hidrofóbicos e hidrofílicos de uma proteína. O caráter anfipático pode ser quantificado mediante o momento hidrofóbico, calculado como sendo a soma vetorial da hidrofobicidade de cada aminoácido, normalizado para uma hélice ideal (Porto et al., 2012). É possível alterar o valor do momento hidrofóbico fazendo mudanças na sequência de aminoácidos. Em 2010, nosso grupo desenvolveu um modelo de desenho racional (máquinas de vetores de suporte, SVM) que utiliza o momento hidrofóbico, em vez de usar a carga líquida, para a previsão da atividade antimicrobiana de peptídeos com motivos de nó de cisteína (Porto, 2010). Desta forma, demonstrou-se que o método SVM de alta confiabilidade permite prever a atividade antimicrobiana independentemente do tamanho do peptídeo. Inclusive, observou-se que um elevado momento hidrofóbico gera um aumento significativo nas atividades hemolítica e de permeabilização dos AMPs frente as membranas alvo (Drin e Antonny, 2010). No entanto, um elevado grau de helicidade e/ou anfipaticidade está correlacionado com o aumento da toxicidade para as células compostas de fosfolipídeos neutros (Dathe et al., 1997; Yeaman e Yount, 2003).

A porcentagem de resíduos hidrofóbicos presentes no peptídeo define a hidrofobicidade. De aproximadamente 50\% para a maioria dos AMPs, a hidrofobicidade aparentemente seria uma característica essencial para as interações peptídeo-membrana, assim como necessária para uma efetiva permeabilização da membrana. No entanto, níveis elevados de hidrofobicidade podem estar correlacionados com uma maior toxicidade em células de mamífero e com a perda da especificidade antimicrobiana (Khandelia et al., 2008; Schmidtchen et al., 2009). Portanto, muitos AMPs podem ser moderadamente hidrofóbicos, de tal modo que obtenham a optimização da sua atividade 
contra membranas de células microbianas.

Ângulo polar consiste em uma medida da proporção relativa das faces polares e não polares de um peptídeo de conformação de hélice anfipática. No caso de um peptídeo helicoidal hipotético, onde uma face pode ser composta exclusivamente de resíduos hidrofóbicos e a outra de resíduos carregados, o ângulo polar seria $180^{\circ}$ (Tossi et al., 2000). Uma segregação reduzida entre estes domínios ou um aumento da proporção hidrofóbica da hélice reduziria proporcionalmente o ângulo polar. Em numerosos estudos de peptídeos naturais e sintéticos, um menor ângulo polar (e, por conseguinte, uma maior superfície hidrofóbica) está associado com o aumento da capacidade para permeabilizar as membranas (Yeaman e Yount, 2003). Também, tem sido demonstrado que o ângulo polar influencia a estabilidade global e a meia-vida dos poros da membrana induzidos por peptídeos (Uematsu e Matsuzaki, 2000).

\section{Abordagens computacionais para o desenvolvimento de novos AMPs}

O uso terapêutico dos AMPs manifesta um possível impedimento que reside na toxicidade frente a células humanas e susceptibilidade à degradação proteolítica que gera uma farmacocinética potencialmente desfavorável (meia-vida curta no sangue). No entanto, este problema foi abordado e várias soluções têm sido propostas, incluindo a incorporação de fragmentos não proteicos; a amidação e acetilação da porção terminal da cadeia peptídica; a síntese de peptídeos contendo D-aminoácidos (em vez de os Laminoácidos de origem natural) que torna os peptídeos resistentes às enzimas plasmáticas, mantendo a atividade antimicrobiana e, muitas vezes, reduzindo a atividade hemolítica (Mangoni et al., 2006; Knappe et al., 2010). Ademais, o uso terapêutico limitado dos AMPs tem a ver em grande medida com o alto custo de fabricação de peptídeos (Marr et al., 2006). O presente cenário tem limitado tanto os testes como o desenvolvimento de um 
grande número de análogos. Porém, foram propostas muitas estratégias para produzir peptídeos na escala e pureza necessários para a aplicação terapêutica, utilizando uma variedade de métodos de DNA recombinante por meio de bactérias e fungos, bem como plantas e sistemas de produção animal.

A bioinformática tem contribuído de forma decisiva no que se refere à identificação e concepção de AMPs, assim como, aos estudos sobre os mecanismos de ação. Desde a década de 1990, vários métodos têm sido aplicados para a concepção racional de AMPs com o objetivo de gerar análogos de tamanho reduzido com atividade antimicrobiana melhorada e baixa toxicidade para as células humanas. Além disso, devido a quantidade limitada de compostos antimicrobianos naturais que pode ser extraída in vivo, a biotecnologia representa um papel central no desenvolvimento de fármacos a partir de AMPs identificados e caracterizados (Afacan et al., 2012).

As estratégias computacionais para o desenho racional, podem ser utilizadas para a descoberta de moléculas candidatas a fármacos, mas também para a otimização de substâncias bioativas já existentes obtidas pelo próprio desenho. A triagem computacional constitui um método altamente automatizado para a identificação de potenciais medicamentos a partir de coleções de compostos reais ou virtuais. Esta técnica permite explorar de forma rápida grandes quantidades de sequências tornando mais simples o trabalho de identificação e seleção de moléculas capazes de interagir com alta afinidade e seletividade com o alvo molecular selecionado (Fjell et al., 2011).

Portanto, podemos fazer uso de técnicas de rastreio de alto rendimento (HTS; HighThroughput Screening) que podem ser feitas in silico (virtual screening), in vivo ou in vitro. Um exemplo disso, a técnica spot array em suporte de celulose, permite sintetizar até 1000 peptídeos de maneira rápida e eficiente em termos de custo (Hilpert et al., 2007; Winkler et al., 2009). Os peptídeos sintetizados em celulose podem ser facilmente 
clivados e a sua atividade antimicrobiana testada com alta sensibilidade, por meio da cepa Pseudomonas aeruginosa H1001, na qual tem sido introduzido o gene que codifica a enzima luciferase bacteriana. Deste modo, detecta-se a presença de células vivas pela oxidação de D-luciferina em presença de ATP, pela análise da intensidade da fluorescência ao longo do tempo (Hilpert et al., 2005; Hilpert e Hancock, 2007).

Por outro lado, a simulação molecular permite a visualização tridimensional e predição teórica das interações entre os AMPs e uma variedade de membranas miméticas (zwitteriônicas, aniônicas). Assim, a partir de mínimas informações experimentais e da sequência primaria, pode ser possível determinar a estrutura tridimensional dos peptídeos e suas interações. Isso nos ajuda a predizer e compreender os mecanismos moleculares da atividade antimicrobiana assim como os efeitos citotóxicos (Langham e Kaznessis, 2010). Contudo, os modelos in silico devem ser integrados aos ensaios in vivo e in vitro com o propósito de diminuir a quantidade de moléculas a serem avaliadas e maximizar as chances de sucesso na identificação de novos AMPs com potencial de desenvolvimento clínico.

\section{Métodos de desenho racional}

A metodologia tradicional responsável pela descoberta da maioria dos fármacos utilizados hoje, consiste no teste direto de compostos naturais ou sintéticos em ensaios biológicos (testes em células ou modelos animais). O processo de purificação, caracterização e síntese de compostos naturais, além de precisar uma grande diversidade de material biológico para testes, tornam o processo trabalhoso, ineficiente e de alto custo. Muitos AMPs de origem natural precisam ser melhorados antes que eles possam ser utilizados como agentes terapêuticos. Nos últimos anos, vem surgindo também uma grande variedade de AMPs produzidos sinteticamente com o objetivo de criar AMPs com 
características físico-químicas desejáveis. Neste contexto, surgem métodos de desenho in silico de moléculas com alta especificidade para patógenos, maior resistência à degradação por proteinases, baixa toxicidade para células eucariotas ou, ainda, técnicas de produção de partes menores a partir de peptídeos complexos que sejam mais facilmente sintetizados para elaboração em larga escala (Fjell et al., 2012).

Atualmente, uma abordagem racional para o desenho de novos fármacos tornou-se uma área de grande destaque na química medicinal. Os métodos de desenho racional de AMPs visam criar um produto farmacêutico com maior especificidade para os microrganismos, evitando efeitos secundários. A descoberta do papel das propriedades físico-químicas dos AMPs permitiu o desenvolvimento de métodos para predizer a atividade antimicrobiana, o que, por sua vez, pode conduzir à identificação prévia de AMPs, antes de sua síntese.

Parâmetros estruturais e físico-químicos tais como a cationicidade, a propensão para estruturação helicoidal, a anfipaticidade, a hidrofobicidade, podem estar intimamente relacionados, de modo que as modificações destinadas a alterar um parâmetro, podem resultar em mudanças significativas para um ou mais dos outros. Compreender e controlar essas inter-relações pode ser a chave para a concepção de novos peptídeos com maior potência e especificidade. Vários métodos de predição de atividade antimicrobiana surgiram a partir de estudos de desenho racional (Lata et al., 2010; Thomas et al., 2010; Porto et al., 2012).

De acordo com Porto et al. (2012), existem quatro tipos de metodologias de desenho racional, que incluem os métodos físico-químicos, os métodos baseados em uma sequência modelo, os métodos evolutivos e os métodos de novo. Embora também existam métodos híbridos, essencialmente, estas quatro classes conseguem definir os métodos de desenho racional. 


\section{- Métodos físico-químicos}

Os primeiros métodos de desenho racional foram baseados no mecanismo de ação mais proposto para os AMPs, a ruptura de membrana. Assim, a maioria dos métodos físico-químicos usam peptídeos com conformação em $\alpha$-hélice como base para o estudo (Porto et al., 2012). Peptídeos com conformação em $\alpha$-hélice apresentam uma ampla distribuição e um grande espectro de atividades, e as suas propriedades físico-químicas (carga total, hidrofobicidade, momento hidrofóbico) podem ser facilmente mensuradas. $\mathrm{O}$ trabalho de Giangaspero et al. (2001) demonstrou que modificações na propensão de formação de $\alpha$-hélice modificam a potência antimicrobiana.

\section{- Métodos baseados em uma sequência modelo}

Enquanto as abordagens baseadas em uma sequência conhecida, a geração de AMPs não depende da atividade antimicrobiana do peptídeo escolhido como modelo. Com o objetivo de reduzir o tamanho, aumentar a seletividade e/ou reduzir o efeito citotóxico de sequências conhecidas, tais abordagens podem utilizar as informações geradas pelos métodos físico-químicos (Ahn et al., 2006). Pode ser possível desenvolver análogos através da substituição de alguns resíduos de aminoácidos para outros com propriedades diferentes. Em 2005, Zelezetsky e colaboradores desenvolveram 6 análogos com base no peptídeo $\mathrm{P} 1\left(\mathrm{Aib}_{7}\right)$ não proteinogênico de estrutura $\alpha$-hélice efetuando uma substituição de aminoácido nas posições estratégicas 7 e/ou 14, demonstrando que pode ser possível modular a natureza lítica do peptídeo e torná-lo mais específico para células microbianas, através de substituições de aminoácidos mínimas (Zelezetsky et al., 2005). Seguindo a mesma estratégia de substituição de aminoácidos, foi possível fazer substituições de forma conservativa (a estrutura terá poucas alterações). Desse modo, 
Ueno e colaboradores no ano 2011, criaram com sucesso novos CAMPs (peptídeos antimicrobianos catiônicos) a partir de sequências de origem natural não antimicrobianas (Ueno et al., 2011). Recentemente, foi desenvolvido pelo nosso grupo de pesquisa, um peptídeo palíndromo rico em alanina, nomeado Pa-MAP2, a partir de um peptídeo sintético obtido do peixe $P$. americanus. O peptídeo Pa-MAP2, desenhado por substituição de aminoácidos, demonstrou baixa toxicidade para células de mamíferos e grande especificidade para membranas aniônicas (Migliolo et al., 2016).

\section{- Métodos evolutivos}

Os métodos evolutivos requerem um maior poder computacional que os dois citados anteriormente. Os métodos evolutivos utilizam algoritmos genéticos que tratam um conjunto de peptídeos como uma população onde cada indivíduo pode ser uma resposta em potencial. O algoritmo força a população de peptídeos a evoluir baseado em uma função de fitness (por exemplo, um score de atividade antimicrobiana) que pode ser maximizada ou minimizada. Este tipo de método tem sido pouco aplicado, existem apenas dois trabalhos que relatam o desenvolvimento de AMPs através de algoritmos genéticos (Patel et al., 1998; Fjell et al., 2011), e que utilizam a mesma função de fitness.

\section{- Métodos de novo}

Contrariamente aos métodos evolutivos que utilizam uma sequência central para desenvolver análogos, os métodos de novo, podem gerar uma grande variedade de sequências usando padrões ou frequências de aminoácidos e as preferências de posicionamento (Porto et al., 2012). A semelhança do método anterior, os métodos de novo precisam de um alto poder computacional. 


\section{Desenho racional de sequências para o trabalho}

\section{Substituição de aminoácidos no peptídeo mastoparano L}

A família de peptídeos mastoparanos consistem em AMPs componentes do veneno de vespa, ricos em resíduos de aminoácidos hidrofóbicos e básicos que adotam uma conformação de $\alpha$-hélice anfipática em ambientes lipídicos. Pertencente a essa família de tetradecapéptidos, o mastoparano L (MP) exibe uma grande variedade de atividades biológicas, entre elas, a capacidade de ativar a liberação dos grânulos de mastócitos que contém histamina, substância envolvida nos processos de reações alérgicas (Hori et al., 2001). Experimentos com membranas modelo tem demonstrado a capacidade do MP de induzir a permeabilização de membranas e a formação de canais iônicos (Mellor e Sansom, 1990; Li et al., 2000). Apesar da sua atividade antimicrobiana, o potencial terapêutico do MP parece ser limitado devido aos efeitos tóxicos frente às células de mamífero. No presente trabalho, com o intuito de reduzir/eliminar a toxicidade do MP, foi desenvolvido o análogo $\left[\mathrm{I}^{5}, \mathrm{R}^{8}\right]$ MP contendo 2 substituições do aminoácido alanina, nas posições 5 e $8\left(\mathrm{Ala}^{5} \rightarrow\right.$ Ile, $\left.\mathrm{Ala}^{8} \rightarrow \mathrm{Arg}\right)$ (Figura 6$)$.

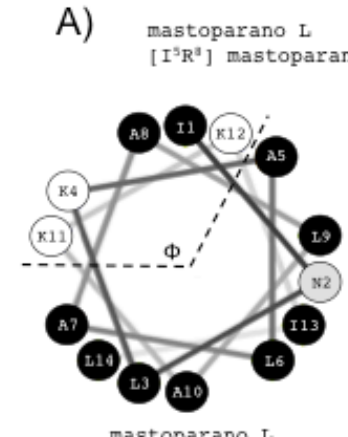

mastoparano L
INLKALAALAKKI

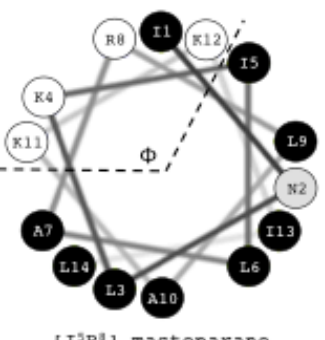

$\left[I^{3} R^{a}\right]$ mastoparano
B)

\begin{tabular}{lcc}
\hline & mastoparano $\mathbf{L}$ & {$\left[\mathbf{I}^{5}, \mathbf{R}^{8}\right]$} \\
\hline Hidrofobicidade & 1.16 & 0.90 \\
$\begin{array}{l}\text { Momento } \\
\text { hidrofóbico }\end{array}$ & 1.00 & 1.39 \\
$\begin{array}{l}\text { Propensão para } \\
\text { hélice }\end{array}$ & 0.22 & 0.27 \\
Carga & +3 & +4 \\
\hline
\end{tabular}

Figura 6. (A) Alinhamento das sequências (acima) e projeções de hélice (abaixo) do peptídeo mastoparano L (MP) e seu análogo $\left[\mathrm{I}^{5}, \mathrm{R}^{8}\right]$ mastoparano $\left(\left[\mathrm{I}^{5}, \mathrm{R}^{8}\right] \mathrm{MP}\right)$. O ângulo da face polar é indicado por $\Phi$. Resíduos de aminoácidos positivamente carregados estão representados como círculos brancos, os polares em cinza e os não-polares em preto. (B) Parâmetros físico-químicos do MP e seu análogo $\left[\mathrm{I}^{5}, \mathrm{R}^{8}\right]$ MP (Irazazabal et al., 2016). 


\section{Algoritmo Joker}

Diversos métodos de desenho de AMPs foram desenvolvidos nos últimos anos. Em 2006, foi proposto um modelo linguístico que estabelece o funcionamento dos AMPs na base de uma linguagem formal, formada por um conjunto de gramáticas (padrões) e um vocabulário (aminoácidos) (Loose et al., 2006). Alguns anos mais tarde, o algoritmo Joker (Porto, 2013) foi desenvolvido baseado no modelo linguístico. O algoritmo Joker consiste em uma nova abordagem do modelo linguístico que gera AMPs baseados em uma sequência conhecida, não importando se as sequências provêm ou não de um peptídeo com atividade antimicrobiana. Para o presente trabalho, o desenho racional através do algoritmo Joker, foi feito utilizando o banco de dados de peptídeos antimicrobianos APD2 (http://aps.unmc.edu/AP/) (Wang et al., 2009) como fonte primária das sequências de peptídeos antimicrobianos. O APD2 foi escolhido como banco primário por ser um banco curado e com uma anotação detalhada, incluindo informações como características estruturais, tipos de organismos contra qual o peptídeo foi detectado ativo (e.g. fungos, bactérias e vírus) e organismo fonte do peptídeo. Através desta estratégia, foram desenvolvidas um total de 100 novas sequências a partir de fragmentos de proteínas retirados da base de dados NCBI. Entre os fragmentos utilizados encontramse a sequência peptídica nomeada PaDBS1, correspondente à proteína ribossomal L39E da arqueia hipertermofílica Pyrobaculum aerophilum, e a sequência peptídica nomeada EcDBS1, correspondente à proteína ligante de mercúrio da bactéria E. coli. Tanto o fragmento PaDBS1 como o EcDBS1, serviram de base ao algoritmo Joker para a geração de 9 análogos cada um. Para o estudo funcional do presente trabalho, foram escolhidos dois análogos, designados PaDBS1R1 e EcDBS1R6 (Figura 7). 
A)

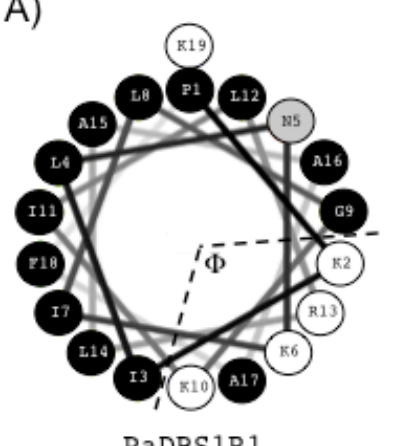

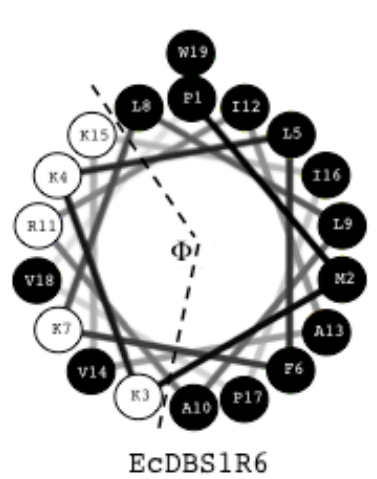

B)

\begin{tabular}{lcc}
\hline & PaDBS1R1 & EcDBS1R6 \\
\hline Hidrofobicidade & 0.60 & 0.68 \\
$\begin{array}{l}\text { Momento } \\
\text { hidrofóbico }\end{array}$ & 1.60 & 1.23 \\
$\begin{array}{l}\text { Propensāo para } \\
\text { hélice }\end{array}$ & 0.46 & 0.61 \\
\begin{tabular}{l} 
Carga \\
\hline
\end{tabular} & +5 & +5 \\
\hline
\end{tabular}

PaDBS1R1

Figura 7. (A) Projeção de hélice e (B) parâmetros físico-químicos dos peptídeos PaDBS1R1 e EcDBS1R6. O ângulo da face polar é indicado por $\Phi$. Resíduos de aminoácidos positivamente carregados estão representados como círculos brancos, os polares em cinza e os não-polares em preto. 


\section{JUSTIFICATIVA}

As infecções relacionadas à assistência à saúde (IRAS) constituem uma importante causa de mortalidade e aumento dos custos hospitalares em países desenvolvidos. Entre os patógenos comumente envolvidos na etiologia das infecções nosocomiais, as bactérias têm adquirido resistência a múltiplos antibióticos o que representa um grave problema não somente na comunidade senão também nos estabelecimentos de cuidados em saúde, onde os pacientes cujo sistema imunológico está comprometido, representam uma população altamente suscetível. Neste contexto, torna-se extremamente importante a busca por novas alternativas para o controle dos microrganismos multirresistentes aos antibióticos convencionais. Hoje em dia, os peptídeos têm sido considerados como uma potencial nova classe de moléculas imunomoduladoras e antimicrobianas. Comumente encontrados em diferentes organismos multicelulares, esses peptídeos antimicrobianos (AMPs) estão presentes em concentrações muito baixas e podem apresentar toxicidade, inviabilizando a sua utilização a partir da purificação de fontes naturais. Neste contexto, surgem métodos de desenho in silico de moléculas como uma alternativa viável para o desenvolvimento de novos fármacos. Com este fim, se propõe avaliar a atividade antimicrobiana e o mecanismo de ação dos peptídeos sintéticos derivados do desenho racional: $\left[\mathrm{I}^{5}, \mathrm{R}^{8}\right]$ mastoparano, EcDBS1R6 e PaDBS1R1. A descoberta de candidatos antimicrobianos poderá propiciar a ampliação de terapêuticas para o controle das IRAS. 


\section{OBJETIVO}

\section{OBJETIVO GERAL}

Avaliar as atividades antimicrobiana, citotóxica e o mecanismo de ação dos peptídeos desenhados in silico $\left[\mathrm{I}^{5}, \mathrm{R}^{8}\right]$ mastoparano, PaDBS1R1 e EcDBS1R6, visando à obtenção de moléculas potenciais para a prevenção e o controle das infecções de microrganismos patogênicos.

\section{OBJETIVOS ESPECÍFICOS}

- Identificar a concentração mínima inibitória (CMI) dos peptídeos contra microrganismos patogênicos causadores de IRAS

- Avaliar a atividade hemolítica e a toxicidade dos peptídeos frente a eritrócitos humanos, macrófagos humanos derivados de monócitos THP-1 e células renais embrionárias humanas HEK-293 in vitro

- Investigar a capacidade dos peptídeos de permeabilizar e despolarizar membranas bacterianas Gram-positivas e Gram-negativas

- Determinar a cinética de ação dos peptídeos frente a bactérias sensíveis Grampositivas e Gram-negativas

- Examinar a morfologia das membranas dos microrganismos sensíveis antes e após a exposição aos peptídeos por meio da visualização de imagens de microscopia eletrônica de varredura (MEV-FEG)

- Determinar a estrutura secundária e terciária dos peptídeos por espectroscopia de dicroísmo circular (DC) e ressonância magnética nuclear (RMN), além de avaliar modelos tridimensionais por meio de modelagem molecular

- Avaliar o comportamento dos peptídeos mediante dinâmica molecular in silico em ambientes de água e de membrana DOPC 


\section{MATERIAL E MÉTODOS}

\section{Desenho racional de peptídeos antimicrobianos: método baseado em sequência modelo}

\section{Substituição de aminoácidos}

A partir da sequência do tetradecapeptídeo mastoparano L (INLKALAALAKKIL) gerou-se o análogo $\left[\mathrm{I}^{5}, \mathrm{R}^{8}\right]$ mastoparano (INLKILARLAKKIL) mediante substituição de aminoácidos. Foi colocado o resíduo de arginina (Arg) na posição 8 de forma a incrementar a carga líquida de +3 até +4 sem modificar o ângulo determinado pela face carregada da hélice (Figura 6). De acordo com a escala de Pace-Scholtz que determina a propensão de $\alpha$-hélice, o aminoácido arginina está classificado como o segundo resíduo com maior propensão (sendo alanina o primeiro) (Pace e Scholtz, 1998). O resíduo isoleucina (Ile) foi colocado na posição 5 com o objeto de contrabalançar a hidrofobicidade do peptídeo, já que Ile e Arg apresentam valores opostos na escala KyteDoolittle de hidrofobicidade: 5.5 e -4.5, respectivamente (Kyte e Doolittle, 1982).

\section{Algoritmo Joker}

A geração de novas sequências realizou-se utilizando o algoritmo Joker que visa a inserção de padrões rígidos em sequências de peptídeos. A partir do banco de dados APD2 foram selecionadas 248 sequências de peptídeos antimicrobianos anotados como $\alpha$ hélices, que logo foram submetidas ao software Pratt 2.1 (Jonassen et al., 1995) para a identificação de padrões. A fim de confirmar a identificação de padrões, realizou-se uma busca de tal padrão em sequencias de peptídeos de 18 aminoácidos no banco de dados do NCBI por meio de um script escrito em PERL. Os padrões rígidos são formados por três componentes: os componentes de identidade (um aminoácido específico em determinada 
posição), os componentes ambíguos (dois ou mais aminoácidos em uma determinada posição) e os componentes curingas (qualquer dos 20 aminoácidos em uma determinada posição) (Figura 1, Apêndice I). Baseado na premissa que o tamanho do padrão rígido pode ser menor que o tamanho da sequência, o algoritmo Joker funciona através do sistema de janela deslizante, onde para cada janela, gera-se um novo análogo do peptídeo original (Porto, 2013).

\section{Síntese de peptídeos - técnica spot array em suporte de celulose}

Os peptídeos desenhados in silico foram sintetizados sobre membrana de celulose utilizando a técnica spot array, produzida pela Kinexus Bioinformatics Corporation (Vancouver, BC). A metodologia desenvolvida por Ronald Frank e colaboradores (Frank, 2002), permite a construção rápida e eficiente de um grande número de sequências peptídicas (até 100 para síntese manual) em pontos, ou spots. Os aminoácidos são depositados em volume mínimo $(0,6 \mu \mathrm{L})$ com auxílio de um micropipetador automático, permitindo obter aproximadamente 50 nmols de peptídeo por spot. Segundo Hilpert et al. (2007), a confiabilidade da metodologia limita-se ao tamanho da sequência entre 6-18 aminoácidos. Após a síntese, os spots de membrana com os diversos peptídeos foram dissolvidos em água destilada overnight e, subsequentemente, avaliada a sua atividade antimicrobiana tal como descrito a seguir.

\section{Determinação da atividade antimicrobiana frente a $P$. aeruginosa bioluminiscente}

A atividade antimicrobiana dos peptídeos sintetizados foi avaliada contra a cepa bioluminescente Pseudomonas aeruginosa $\mathrm{H} 1001$ em placa de 96 poços tal como descrito 
anteriormente, com algumas modificações (Hilpert et al., 2005; Hilpert e Hancock, 2007). As soluções aquosas de peptídeos liberados a partir do suporte de celulose, foram diluídas duas vezes em meio BM2 (62 mM de tampão fosfato de potássio $\mathrm{pH}=7,7 \mathrm{mM}\left(\mathrm{NH}_{4}\right)_{2}$ $\mathrm{SO}_{4}, 2 \mathrm{mM} \mathrm{MgSO} 4,10 \mu \mathrm{M} \mathrm{FeSO}_{4}, 0,4 \%$ glucose [m:v]), atingindo um volume final de 25 $\mathrm{uL}$ em cada poço. Subsequentemente, $50 \mu \mathrm{L}$ de cultura overnight de P. aeruginosa H1001 (fliC :: luxCDABE) foram subcultivados em $5 \mathrm{~mL}$ de meio $\mathrm{LB}$ e crescidos até $\mathrm{Abs}_{600}$ de 0,4. Esta cultura foi então diluída 4:100 (v:v) em meio BM2 e $25 \mu \mathrm{L}$ e transferida para os poços da microplaca contendo $25 \mu \mathrm{L}$ de solução de peptídeo $\left(200-3 \mu \mathrm{g} \cdot \mathrm{mL}^{-1}\right.$, concentrações finais). As microplacas foram incubadas durante $4 \mathrm{~h}$ a $37^{\circ} \mathrm{C}$ sob agitação constante de $50 \mathrm{rpm}$. A luminescência foi medida em leitor de microplacas Tecan SPECTRAfluor Plus (Tecan EUA, Morrisville, NC). A atividade antimicrobiana foi avaliada pela capacidade dos peptídeos para reduzir a luminescência de $P$. aeruginosa H1001, em comparação com as bactérias não tratadas. Os peptídeos magainina2 e meropenem carbapenem foram usados como controles positivos e, o controle negativo corresponde as bactérias em presença de água destilada.

\section{Síntese dos peptídeos escolhidos e confirmação da identidade por espectrometria de massas}

Após a escolha das sequências peptídicas pela estratégia de síntese spot array acoplada a análise de atividade antimicrobiana frente a $P$. aeruginosa bioluminescente; os 4 peptídeos selecionados foram sintetizados através de um protocolo de síntese química, purificados $(>95 \%)$, liofilizados e armazenados pela Peptide 2.0 Inc., EUA. A síntese foi realizada de acordo com a metodologia em fase sólida F-moc (envolve o uso de 9fluorenilmetoxicarbonila protetor do grupo amino). A verificação de massas moleculares e o grau de pureza dos peptídeos sintetizados foi realizada utilizando a análise de 
MALDI-ToF ToF (Matrix-assisted laser desorption/ionization time of flight mass spectrometry) em UltraFlex III, Bruker Daltonics ${ }^{\circledR}$, Billerica, MA. Os peptídeos foram dissolvidos em um volume mínimo de água, misturados com uma solução saturada de ácido matriz $\alpha$-ciano-4-hidroxicinâmico (1:3; v:v). As amostras foram secas à temperatura ambiente sobre uma placa de MALDI. A solução de ácido matriz foi preparada em $\mathrm{H}_{2} \mathrm{O}$ :ACN:TFA nas proporções 50:50:0,3; v:v:v. A massa monoisotópica dos peptídeos foi obtida em modo refletor com a calibração externa utilizando o peptídeo de calibração padrão II por espectrometria de massa (até 4000 Da gama de massas, Bruker Daltonics, Billerica, MA).

\section{Determinação da concentração mínima inibitória (CMI) antibacteriana}

A atividade antibacteriana in vitro dos peptídeos foi avaliada pelo ensaio modificado de inibição do crescimento por microdiluição em caldo, de acordo com o NCCLS (National Committee for Clinical Laboratory Standards) (Nccls, 2003). Foram utilizadas as cepas de bactérias Gram-negativas e Gram-positivas: Staphylococcus aureus ATCC 25923, Enterococcus faecalis ATCC 29212, Escherichia coli ATCC 25922, Pseudomonas aeruginosa ATCC 27853, Acinetobacter baumannii ATCC 19606, Klebsiella pneumoniae ATCC 13883 e os isolados clínicos S. aureus resistente a meticilina (7133623) (MRSA) e K. pneumoniae resistente a carbapenêmicos (3259271) (KPC), cultivadas em ágar LB (Lysogeny Broth). As duas cepas Gram-positivas Streptococcus pyogenes ATCC 19615 e Listeria ivanovii Li 4pVS2 foram cultivadas em ágar BHI (Brain Heart Infusion). A partir de colônias frescas, preparou-se um cultivo mãe que foi diluído em meio MH (Muller Hinton) de maneira seriada para determinar a carga bacteriana e obter uma suspensão com absorbância no cumprimento de onda de $630 \mathrm{~nm}$ $\left(\mathrm{A}_{630}\right)$ desejada, com a exceção de $S$. pyogenes, L. ivanovii e E. faecalis que foram 
diluídos em seus respectivos meios de cultura. Foram utilizados inóculos na fase de crescimento exponencial, na concentração aproximada de $10^{6} \mathrm{UFC} \cdot \mathrm{mL}^{-1}\left(\mathrm{~A}_{630}=0,01\right)$. A concentração mínima inibitória (CMI) foi determinada em placa de 96 poços, contendo $50 \mu \mathrm{L}$ da suspensão bacteriana e $50 \mu \mathrm{L}$ do peptídeo em diluições seriadas (200 até $1 \mu \mathrm{M}$, concentração final). Após incubação durante a noite a $37{ }^{\circ} \mathrm{C}$ sob agitação a $150 \mathrm{rpm}$, a inibição do crescimento bacteriano foi avaliada pela leitura de absorbância pontual a $A_{630}$ utilizando um leitor de microplaca (UVM 340, Asys Hitech). A menor concentração que inibir o $100 \%$ crescimento bacteriano é considerada a CMI, correspondente à media dos resultados obtidos a partir de 3 experiências independentes realizadas em triplicata. $\mathrm{O}$ controle positivo (considerado como $100 \%$ de inibição de crescimento bacteriano) corresponde à suspensão bacteriana em presença de formaldeído $0,7 \%$ (v:v) e o controle negativo em ausência de peptídeo (Andre et al., 2015).

\section{Determinação da concentração mínima inibitória (CMI) antifúngica}

A atividade antifúngica dos peptídeos foi avaliada também pelo ensaio de microdiluição em caldo utilizando as cepas Candida albicans ATCC 90028 e C. parapsilosis ATCC 22019, cultivadas a partir de colônias frescas em ágar contendo levedura, peptona e dextrose (Yeast Peptone Dextrose - YPD) por $48 \mathrm{~h}$ à $30^{\circ} \mathrm{C}(\mathrm{Nccls}$, 2003). O valor de CMI foi determinado pela medição da $A_{630}$ em placa de 96 poços contendo $50 \mu \mathrm{L}$ da suspensão de fungos na fase do crescimento exponencial à $10^{6}$ UFC.mL $L^{-1}$ em meio líquido YPD junto a $50 \mu \mathrm{L}$ do peptídeo em diluições seriadas (200 até $1 \mu \mathrm{M}$, concentração final), após incubação durante a noite a $30{ }^{\circ} \mathrm{C}$ e $150 \mathrm{rpm}$. A concentração mínima inibitória (CMI) foi assumida como sendo a menor concentração onde não houve crescimento dos fungos detectável espectrofotometricamente, correspondente a média dos resultados obtidos a partir de 3 experiências independentes 
realizadas em triplicata. O controle positivo corresponde á suspensão bacteriana em presença de formaldeído $0,7 \%$ (v:v) e o controle negativo em ausência de peptídeo (Andre et al., 2015).

\section{Ensaio hemolítico}

O ensaio utilizado para determinar a atividade hemolítica dos peptídeos, foi modificado do protocolo descrito por Bignami (1993). Resumidamente, o sangue humano de pacientes saudáveis foi coletado, os eritrócitos foram separados do plasma por centrifugação (1500 rpm), lavados três vezes com $50 \mathrm{mM}$ tampão fosfato, pH 7,4, e incubados com o peptídeo (400 até $1 \mu \mathrm{M}$, concentração final). Os peptídeos foram adicionados na suspensão de eritrócitos (1\%, v:v) no volume final de $100 \mu \mathrm{L}$ e incubados à $37{ }^{\circ} \mathrm{C}$ durante $60 \mathrm{~min}$ em placa de 96 poços. Após incubação, a liberação de hemoglobina foi determinada espectrofotometricamente pela leitura de $\mathrm{A}_{540}$ em leitor de microplacas (Bio-Tek). O controle de $0 \%$ hemólise corresponde à suspensão de eritrócitos em presença de $50 \mathrm{mM}$ de buffer fosfato, $\mathrm{pH} 7,4 \mathrm{e}$, como controle positivo ( $100 \%$ de lise) foi usada uma suspensão de eritrócitos incubados com uma solução de Triton X-100 1\% (v:v). Os resultados foram expressos pela concentração de peptídeo capaz de produzir $50 \%$ de hemólise (concentração lítica $50, \mathrm{LC}_{50}$ ).

\section{Avaliação citotóxica dos peptídeos in vitro}

A avaliação da citotoxicidade dos peptídeos foi realizada frente a macrófagos humanos derivados de monócitos THP-1 (gentilmente fornecidas pelo Dr. B. Oury, IRD, Montpellier, França) e células renais embrionárias humanas HEK-293 (gentilmente fornecidas pelo Dr. O. Jean-Jean, IBPS, UPMC, Paris, França). Os monócitos THP-1 
foram cultivados em RPMI 1640 (Life Technologies), suplementado com 10\% soro fetal bovino (do inglês FBS), 25 mM HEPES, GlutaMax 1\%, $1 \mathrm{mM}$ piruvato sódico, penicilina (100 U.mL $\left.L^{-1}\right)$ e estreptomicina $\left(100 \mu \mathrm{g} \cdot \mathrm{mL}^{-1}\right)$. O meio de cultura utilizado para o crescimento das células HEK-293 foi DMEM (Life Technologies) suplementado com 10\% FBS, penicilina $\left(100 \mathrm{U} \cdot \mathrm{mL}^{-1}\right)$ e estreptomicina $\left(100 \mu \mathrm{g} \cdot \mathrm{mL}^{-1}\right)$. Ambas linhagens celulares foram incubadas a $37{ }^{\circ} \mathrm{C}, 5 \%$ de $\mathrm{CO}_{2}$ e $95 \%$ de umidade. Os monócitos THP-1 foram diferenciados a macrófagos por adição de 20 ng.mL ${ }^{-1}$ PMA (do inglês, phorbol 12 myristate 13-acetate) no meio de cultura contendo as células na concentração $5 \times 10^{5}$ celulas.mL $\mathrm{mL}^{-1}$, semeados em microplacas de 96 poços $(100 \mu \mathrm{L}$ por poço) e incubadas por $48 \mathrm{~h}$ a $37^{\circ} \mathrm{C}$. Após lavagem (2 vezes) com RPMI 1640, os macrófagos foram incubados durante $24 \mathrm{~h}$ a $37^{\circ} \mathrm{C}$ com $100 \mu \mathrm{L}$ do peptídeo diluído em meio de cultura (200 até 12,5 $\mu \mathrm{M}$, concentração final). As células HEK-293 foram semeadas em placa de 96 poços (100 $\mu \mathrm{L}$ por poço) na densidade de $5 \times 10^{5}$ células. $\mathrm{mL}^{-1}$ e incubadas durante a noite a $37^{\circ} \mathrm{C}$. Após incubação, as células foram lavadas com DMEM e incubadas durante $24 \mathrm{~h}$, a $37^{\circ} \mathrm{C}$ com $100 \mu \mathrm{L}$ do peptídeo diluído em meio de cultura (200 até $12,5 \mu \mathrm{M}$, concentração final). O ensaio para determinar a atividade citotóxica dos peptídeos foi realizado de acordo com a análise de viabilidade celular empregando o ensaio colorimétrico MTT. Este ensaio consiste na avaliação da atividade da enzima desidrogenase mitocondrial. $\mathrm{O}$ método MTT, fundamenta-se na capacidade das células vivas de reduzirem o sal 3-(4,5di-metilazol-2-il)-2,5-difenil tetrazolium brometo no produto formazam, insolúvel em água (Van De Loosdrecht et al., 1991). O ensaio MTT, distingue as células vivas das células mortas, quantificando a produção de formazam, um produto de cor azulada, como uma medida direta da viabilidade celular. $10 \mu \mathrm{L}$ de MTT $5 \mathrm{ng} \cdot \mathrm{mL}^{-1}$ foram adicionados á placa de 96 poços. Após $4 \mathrm{~h}$ de incubação a $37{ }^{\circ} \mathrm{C}$ no escuro, os cristais de formazan foram solubilizados com $100 \mu \mathrm{L}$ de uma solução contendo $40 \%$ dimetilformamida em $2 \%$ 
ácido acético glacial, 15\% SDS, pH 4,7, seguidos de $1 \mathrm{~h}$ de incubação a $37{ }^{\circ} \mathrm{C}$ sob agitação a $150 \mathrm{rpm}$. Os grupos controle foram representados por poços com (1) células e meio de cultura, representando $100 \%$ de viabilidade celular; (2) células, meio de cultura e solução de lise, representando $0 \%$ de viabilidade celular; e (3) meio de cultura (branco). Finalmente, a absorbância foi determinada em leitor de microplacas à $570 \mathrm{~nm}$ (Asys Hitech UVM 340) usando como referência o cumprimento de onda de $630 \mathrm{~nm}$. Os resultados foram expressos pela concentração de peptídeo capaz de reduzir em $50 \%$ (concentração lítica 50, $\mathrm{LC}_{50}$ ) a viabilidade celular utilizando o software GraphPad Prism ${ }^{\circledR}$ 5.0. A viabilidade celular foi determinada pela média da triplicata de cada concentração testada em três experimentos independentes (Abbassi et al., 2013).

\section{Avaliação da permeabilização de membranas bacterianas induzida por peptídeos}

O efeito dos peptídeos sobre a permeabilidade da membrana plasmática das bactérias Gram-negativa E. coli ATCC 25922 e Gram-positiva S. aureus ATCC 25923, foi avaliado mediante o uso da sonda fluorescente SYTOX green (SG) (Thevissen et al., 1999). As células sadias não permitem a entrada da sonda SG, entretanto quando a membrana das células sofre alterações, a sonda penetra na célula e se associa aos ácidos nucleicos, que conduz a um aumento de fluorescência. Células bacterianas em crescimento exponencial foram centrifugadas $\left(1000 \mathrm{x} \mathrm{g}, 10 \mathrm{~min}, 4{ }^{\circ} \mathrm{C}\right)$, lavadas $\mathrm{e}$ ressuspendidas em PBS $\left(\mathrm{NaCl} 1 \mathrm{M}, \mathrm{Na}_{2} \mathrm{HPO}_{4} 0,1 \mathrm{M}, \mathrm{pH} 7,3\right)$ até $\mathrm{A}_{630}$ de 0,01 . Um volume de $792 \mu \mathrm{L}$ da suspensão bacteriana contendo $6 \times 10^{5}$ UFC. $\mathrm{mL}^{-1}$, foi incubado com $8 \mu \mathrm{L}$ de SG $100 \mu \mathrm{M}$ durante $30 \mathrm{~min}$ a $37^{\circ} \mathrm{C}$ no escuro. Após a adição do peptídeo (200 $\mu \mathrm{L}$, concentração final, 2 vezes superior ao valor da CMI), a fluorescência foi monitorada durante 20 min a $37^{\circ} \mathrm{C}$ no espectrofotómetro de fluorescência Varian Cary Eclipse, com 
excitação e emissão em 485 e $520 \mathrm{~nm}$, respectivamente. Dois controles experimentais foram utilizados: o controle negativo, correspondente à células em presença de PBS e o controle positivo, correspondente à células em presença do peptídeo formador de poros na membrana, melitina (Rex, 1996). Foram realizadas três experiências independentes e os resultados correspondem a uma experiência representativa.

\section{Avaliação da despolarização de membranas bacterianas induzida por peptídeos}

O efeito dos peptídeos sobre a polarização da membrana plasmática de bactérias Gram-negativa E. coli ATCC 25922 e Gram-positiva S. aureus ATCC 25923, foi avaliado mediante o uso da sonda fluorescente DiSC3(5) (3,3'-dipropylthiadicarbocyanine iodide) (Sims et al., 1974). A sonda sensível ao potencial de membrana DiSC3(5) permite monitorar a despolarização da membrana plasmática induzida por peptídeos pela mudança da intensidade de emissão de fluorescência. Esta sonda catiônica e lipofílica, acumula-se dentro da bicamada lipídica das membranas celulares e, em seguida, agrega-se causando uma diminuição da sua fluorescência. Os agentes despolarizadores que geram a perda do potencial de membrana provocam a liberação da sonda e, desta forma, ocorre o aumento de fluorescência que pode ser monitorado ao longo do tempo. Para o experimento, células bacterianas em crescimento exponencial foram centrifugadas $\left(1000 \mathrm{x} \mathrm{g}, 10 \mathrm{~min}, 4{ }^{\circ} \mathrm{C}\right)$, lavadas e ressupendidas em $\mathrm{PBS}\left(\mathrm{NaCl} 1 \mathrm{M}, \mathrm{Na}_{2} \mathrm{HPO}_{4} 0,1 \mathrm{M}, \mathrm{pH} 7,3\right)$ até $\mathrm{A}_{630}$ de $0,1(1 \mathrm{x}$ $10^{7} \mathrm{UFC}^{-1} \mathrm{~mL}^{-1}$ ). Um volume de $700 \mu \mathrm{L}$ da suspensão bacteriana contendo DiSC3(5) $1 \mu \mathrm{M}$ foi pre-incubado no escuro durante $10 \mathrm{~min}$ a $37^{\circ} \mathrm{C}$ para permitir a máxima absorção da sonda (maximal dye uptake and fluorescence quenching). Para equilibrar as concentrações citoplasmáticas e externas de $\mathrm{K}^{+}, 100 \mu \mathrm{L}$ de $\mathrm{KCl} 1 \mathrm{mM}$ foram adicionados. Após a adição do peptídeo ( $200 \mu \mathrm{L}$, concentração final, 2 vezes superior ao valor da CMI), mudanças na 
fluorescência foram monitoradas a $37^{\circ} \mathrm{C}$ durante um período de 20 minutos empregandose o espectrofotómetro de fluorescência Varian Cary Eclipse, com excitação e emissão em 622 e $670 \mathrm{~nm}$, respectivamente (Andre et al., 2015). Dois controles experimentais foram utilizados: o controle negativo, correspondente à células em presença de PBS e o controle positivo, correspondente à células em presença do peptídeo formador de poros na membrana, melitina (Rex, 1996). Foram realizadas três experiências independentes e os resultados correspondem a uma experiência representativa.

\section{Ensaios time-kill}

A cinética de ação bactericida (time-kill) dos peptídeos desenhados foi investigada frente as bactérias Gram-negativa E. coli ATCC 25922 e Gram-positiva $S$. aureus ATCC 25923, com uma concentração de peptídeo duas vezes superior ao valor da CMI. Cultivos bacterianos em fase de crescimento exponencial, foram centrifugados (1000 g, $10 \mathrm{~min}$, $\left.4^{\circ} \mathrm{C}\right)$, lavados três vezes com PBS (10 mM fosfato, $100 \mathrm{mM} \mathrm{NaCl}, \mathrm{pH}$ 7,3), e em seguida,

suspensos em PBS para obter uma concentração de $10^{6}$ UFC.mL ${ }^{-1}$. Foram incubados 100 $\mu \mathrm{L}$ desta suspensão bacteriana a $37^{\circ} \mathrm{C}$ com $100 \mu \mathrm{L}$ de PBS contendo os peptídeos. Alíquotas de $10 \mu \mathrm{L}$ foram retiradas a diferentes tempos, diluídas em meio $\mathrm{LB}$, e espalhadas em placas de LB-agar. Após incubação durante a noite a $37^{\circ} \mathrm{C}$, os valores de UFC foram obtidos. Se realizaram controles em ausência de peptídeo. Duas replicas do experimento foram realizadas em triplicata para determinar a cinética do time-kill (Abbassi et al., 2013).

\section{Microscopia eletrônica de varredura com fonte de emissão de campo (MEV- FEG)}


A fim de observar possíveis alterações morfológicas na superfície das células em presença dos peptídeos desenhados, foram obtidas imagens de alta resolução utilizando microscopia eletrônica de varredura com fonte de emissão de campo (MEV-FEG, do inglês Scanning Electron Microscopy with Field Emission Gun), para os seguintes microrganismos: P. aeruginosa ATCC 27853, L. ivanovii Li 4pVS2 e C. albicans ATCC 90028. As células microbianas em fase semi-logarítmica foram centrifugadas (1000 x g, 10 min, $4{ }^{\circ} \mathrm{C}$ ), lavadas duas vezes com PBS, e ressuspendidas no mesmo tampão na concentração $2 \times 10^{7}$ UFC.mL ${ }^{-1}$. Alíquotas de $200 \mu \mathrm{L}$ da suspensão de microrganismos foram incubadas $1 \mathrm{~h}$ a $37^{\circ} \mathrm{C}$ com o peptídeo em concentrações finais correspondentes à CMI e duas vezes acima da CMI. O controle negativo corresponde às células incubadas em PBS na ausência do peptídeo. As células foram fixadas com glutaraldeído 2,5\%, homogeneizadas invertendo suavemente os tubos e armazenadas a $4{ }^{\circ} \mathrm{C}$. As imagens SEM-FEG foram obtidas no microscópio modelo Hitachi SU-70. As amostras foram colocadas em suporte de ouro, onde $20 \mu \mathrm{L}$ do inóculo foram depositados e secos sob atmosfera de nitrogênio, em seguida as amostras foram fixadas sobre um suporte de alumina SEM, recobertas com carbono, e observadas sem metalização. O detector de elétrons secundário Lens (SE-Lower) foi utilizado para caracterizar as amostras. A voltagem de aceleração foi de $1 \mathrm{kV}$ e a distância de trabalho foi de cerca de $15 \mathrm{~mm}$. Foram analisadas em cada superfície pelo menos 5-10 locais diferentes, o que levou à observação de um mínimo de 100 células individuais.

\section{Experimentos de espectroscopia de dicroísmo circular}

Os espectros de dicroísmo circular (DC) foram obtidos em colaboração com o Dr. Luciano Liao e a Dra. Eliane Santana Fernandes Alves do Departamento de Química da 
Universidade Federal de Goiás (UFG). Os experimentos foram realizados em espectropolarímetro JASCO J-815, equipado com um controlador de temperatura Peltier, modelo PTC-423L/15. Utilizou-se um volume de amostra igual a $300 \mu \mathrm{L}$, em cubeta de caminho ótico de $1 \mathrm{~mm}$, na temperatura de $25{ }^{\circ} \mathrm{C}$, fazendo-se 6 varreduras entre os comprimentos de onda de 190 e $260 \mathrm{~nm}$, com velocidade de varredura de $50 \mathrm{~nm} \cdot \mathrm{min}^{-1}$, coleta de dados de $0,2 \mathrm{~nm}$ e tempo de resposta de $1 \mathrm{~s}$, com $1 \mathrm{~nm}$ de largura de banda. Adquiriu-se também espectros, nas mesmas condições, de amostras sem os peptídeos (branco), os quais, por sua vez, foram subtraídos dos espectros adquiridos das amostras com peptídeos. Todos os processamentos foram realizados fazendo uso do software SpectraAnalysis, o qual integra a plataforma Spectra Manager. As deconvoluções de todos os espectros, com vistas a se estimar o teor de formação de hélice $(\mathrm{H})$ em função do número de ligações peptídicas (n) foram feitas utilizando a fórmula $H=[\theta] 222$ / [-40000 $(1-2,5 / n)]$.

\section{Experimentos de RMN}

Os experimentos de ressonância magnética nuclear (RMN) foram obtidos em colaboração com o Dr. Luciano Liao e a Dra. Eliane Santana Fernandes Alves do Departamento de Química da Universidade Federal de Goiás (UFG). Fazendo uso de um espectrômetro Bruker Avance III 500, operando na frequência de $500.13 \mathrm{MHz}$ para o núcleo de hidrogênio, e uma sonda de detecção inversa, provida com três canais e gradiente em Z, realizaram-se experimentos unidimensionais de ${ }^{1} \mathrm{H}$ e os experimentos bidimensionais TOCSY, NOESY e HSQC. Os parâmetros de aquisição utilizados em cada experimento são mostrados na Tabela 3, os quais foram escolhidos após experimentos preliminares de otimização. O volume de $500 \mu \mathrm{L}$ de uma solução de peptídeo de concentração igual a $100 \mathrm{mM}$, tendo como solvente $\mathrm{H}_{2} \mathrm{O}: \mathrm{D}_{2} \mathrm{O}$ na proporção 
de 9:1, e ainda, $50 \mu \mathrm{L}$ de solução $5 \%(\mathrm{~m} / \mathrm{v})$ contendo o padrão interno DSS, foi transferido para um tubo de RMN de $5 \mathrm{~mm}$. Os experimentos foram realizados sem giro e na temperatura de $25{ }^{\circ} \mathrm{C}$, exceto nos casos em que avaliou-se a influência da temperatura nos padrões espectrais obtidos. Antes da realização dos experimentos, procedeu-se ao ajuste automático da homogeneidade do campo magnético (shiming), à calibração do pulso de $90^{\circ}$ e, também, da frequência (tunning e matching).

Tabela 3. Parâmetros para aquisição de experimentos de RMN

\begin{tabular}{ccccc}
\hline \multirow{2}{*}{ Parâmetros } & \multicolumn{5}{c}{ Experimentos de RMN } \\
\cline { 2 - 5 } & ${ }^{1} \mathbf{H}$ & TOSCY & NOESY & HSQC \\
\hline SW (Hz) & 12.0161 & $8.012,82$ & 12.0161 & $\mathrm{~F}_{2}=16.0214$ \\
& & & & $\mathrm{~F}_{1}=90.0036$ \\
NS & 32 & 128 & 16 & 132 \\
$\mathbf{O}_{\mathbf{1}}(\mathbf{H z})$ & $2.346,79$ & $2.349,61$ & $2.349,09$ & $\mathrm{~F}_{2}=2.348,88$ \\
& & & & $\mathrm{~F}_{1}=4.401,52$ \\
$\mathbf{p}_{1}(\boldsymbol{\mu s e c})$ & 7,66 & 7,66 & 7,17 & 7,66 \\
TD & 6.5536 & $\mathrm{~F}_{2}=4.096$ & $\mathrm{~F}_{2}=4.096$ & $\mathrm{~F}_{2}=4.096$ \\
& & $\mathrm{~F}_{1}=256$ & $\mathrm{~F}_{1}=160$ & $\mathrm{~F}_{1}=256$ \\
PIW9 (W) & $4,67.10^{-5}$ & $4,67.10^{-5}$ & - & $4.67 .10^{-5}$ \\
$\mathbf{D} 8(\mathbf{m s})$ & - & - & 250 & - \\
\hline
\end{tabular}

\section{Modelagem molecular}

A busca pelos moldes estruturais foi feita por meio do servidor HHPred (Soding et al., 2005). Para a construção de modelos tridimensionais de peptídeos, foi realizada uma pesquisa usando os códigos PDB. Utilizou-se o código 1D7N para o peptídeo $\left[\mathrm{I}^{5}, \mathrm{R}^{8}\right] \mathrm{MP}$ e o código 3J46 para o peptídeo EcDBS1R6, sendo utilizada a cadeia $\mathrm{N}$ do complexo proteico neste caso, por apresentar a maior identidade de sequência. Os modelos 
tridimensionais teóricos foram construídos usando MODELLER 9.14 (Webb e Sali, 2014), e selecionados de acordo com a pontuação de energia optimizada (DOPE score); que indica as melhores estruturas possíveis. A geometria, estereoquímica, e a energia de distribuição dos melhores modelos, foram avaliadas por meio de PROSA II (Wiederstein e Sippl, 2007) e PROCHECK (Laskowski et al., 1993). PROCHECK verifica a qualidade estereoquímica da estrutura da proteína através do gráfico de Ramachandran, para o qual os modelos de boa qualidade apresentam $>90 \%$ dos resíduos de aminoácidos nas regiões mais favoráveis e permitidas, enquanto PROSA II indica a qualidade de dobramento. A visualização da estrutura foi realizada em PyMOL (http://www.pymol.org).

\section{Dinâmica molecular em água}

Utilizando o modelo de água Single Point Charge (Berendsen et al., 1981); foram realizadas as simulações dos peptídeos em um ambiente aquoso. As análises foram realizadas utilizando o campo de força GROMOS96 43A1 e o pacote computacional GROMACS 4 (Hess et al., 2008). A dinâmica utiliza os modelos moleculares dos peptídeos como as estruturas iniciais, imersas em moléculas de água em uma caixa cúbica com distância mínima de 10 Å entre o peptídeo e os limites do caixa. A fim de neutralizar a carga do sistema, foram adicionados íons cloro. A geometria das moléculas de água foi condicionada utilizando o algoritmo SETTLE (Miyamoto e Kollman, 1992). Todos os comprimentos das ligações entre átomos foram vinculados usando o algoritmo LINCS (Hess et al., 1997). As correções eletrostáticas foram feitas de acordo com o algoritmo Particle Mesh Ewald (Darden et al., 1993), com um limite de raio de 1,4 nm, a fim de minimizar o tempo de cálculo. O mesmo limite de raio também foi utilizado para as interações de van der Waals. A lista dos vizinhos de cada átomo foi atualizada a cada 10 passos de simulação de 2 fs. $\mathrm{O}$ sistema foi submetido a uma minimização de energia 
usando 50.000 passos do algoritmo Steep Descent. Após isso, a temperatura do sistema foi normalizada a $310 \mathrm{~K}$ para $100 \mathrm{ps}$, utilizando o termostato velocity rescaling (conjunto NVT). Em seguida, a pressão do sistema foi normalizada a 1 bar para 100 ps, usando o baróstato Parrinello-Rahman (conjunto NPT). Os sistemas com energia minimizada, temperatura equilibrada e pressão foram simulados para $100 \mathrm{~ns}$, utilizando o algoritmo leap-frog (Van Gunsteren e Berendsen, 1988). As estruturas foram salvas a cada 2 ps de simulação.

\section{Dinâmica molecular em membrana DOPC}

O modelo molecular ou estrutura por RMN dos peptídeos foi colocado na membrana utilizando o servidor CHARMM-GUI (Wu et al., 2014). A simulação foi realizada para o modelo de membranas miméticas dioleolylphosphatidylcholine (DOPC). $\mathrm{O}$ eixo principal do peptídeo foi alinhado com o eixo $\mathrm{Z}$ e, em seguida, inserido na bicamada retangular DOPC de $50 \AA^{2}$ (eixos X e Y) utilizando o método de inserção para a construção do sistema. A simulação foi realizada de forma semelhante à simulação em água, com pequenas modificações. $\mathrm{O}$ sistema foi simulado utilizando o campo de força GROMOS96 53a6 ampliado para os lipídios Berger (Berger et al., 1997). O arquivo de topologia e os parâmetros lipídicos foram obtidos a partir do sítio web de Dr. Tieleman (http://wcm.ucalgary.ca/tieleman/downloads). No conjunto NVT, a temperatura do sistema foi normalizada a $310 \mathrm{~K}$ para 100 ps, usando o termostato velocity rescaling. Para o conjunto de NPT, utilizou-se o termostato Nosé-Hoover, e a pressão do sistema foi normalizada a 1 bar por meio do barostato Parrinello-Rahman com a pressão de acoplamento semi-isotrópica e uma constante de acoplamento de 1 ns. Os sistemas com energia minimizada, temperatura equilibrada e pressão foram simulados para 100 ns, utilizando o algoritmo leap-frog (Van Gunsteren e Berendsen, 1988). 


\section{RESULTADOS}

\section{Desenho racional e seleção de sequências}

As novas sequencias obtidas a partir do algoritmo Joker e da estratégia de substituição de aminoácidos, foram submetidas à avaliação de atividade antimicrobiana frente a bactéria $P$. aeruginosa H1001 bioluminiscente, utilizando a estratégia de síntese spot array em membrana de celulose. As sequências selecionadas $\left[\mathrm{I}^{5}, \mathrm{R}^{8}\right] \mathrm{MP}$, EcDBS1R6 e PaDBS1R1 apresentaram uma potente atividade contra a bactéria com valores de MIC no intervalo $6-6,25 \mu \mathrm{M}$ (Tabela 1, Apêndice I). A Tabela 4 resume as principais informações das sequências selecionadas.

Tabela 4. Sequências desenhadas selecionadas para avaliação funcional.

\begin{tabular}{l|l|c|c|c}
\hline \multicolumn{1}{c|}{ Nome } & $\begin{array}{c}\text { Método de } \\
\text { desenho }\end{array}$ & $\begin{array}{c}\text { Sequência } \\
\text { amino }\end{array}$ & $\begin{array}{c}\text { Massa } \\
\text { molecular (Da) }\end{array}$ \\
\hline $\begin{array}{l}{\left[\mathrm{I}^{5}, \mathrm{R}^{8}\right]} \\
\text { mastoparano }\end{array}$ & $\begin{array}{l}\text { Substituição } \\
\text { de aas }\end{array}$ & INLKILARLAKKIL & 14 & 1606.091 \\
\hline EcDBS1R6 & $\begin{array}{l}\text { Algoritmo } \\
\text { Joker }\end{array}$ & PMKKLFKLLARIAVKIPVW & 19 & 2250.406 \\
\hline PaDBS1R1 & $\begin{array}{l}\text { Algoritmo } \\
\text { Joker }\end{array}$ & PKILNKILGKILRLAAAFK & 19 & 2106.366 \\
\hline
\end{tabular}

\section{Confirmação da identidade e pureza dos peptídeos por espectrometria de massas}

As análises realizadas por espectrometria de massas MALDI-ToF confirmaram as massas de $\left[\mathrm{I}^{5}, \mathrm{R}^{8}\right] \mathrm{MP}$, EcDBS1R6 e PaDBS1R1 (Tabela 4), gerando íons de m/z em 1607.26, 2251.40 e 2107.38 Da, respectivamente (Figura 8). Do mesmo modo, a análise de massas para os peptídeos amidados em C-terminal $\left[\mathrm{I}^{5}, \mathrm{R}^{8}\right]$ MP e PaDBS1R1 confirmaram a sua identidade e pureza (Figura $8 \mathrm{~B}$ e $\mathrm{E}$, respectivamente). 

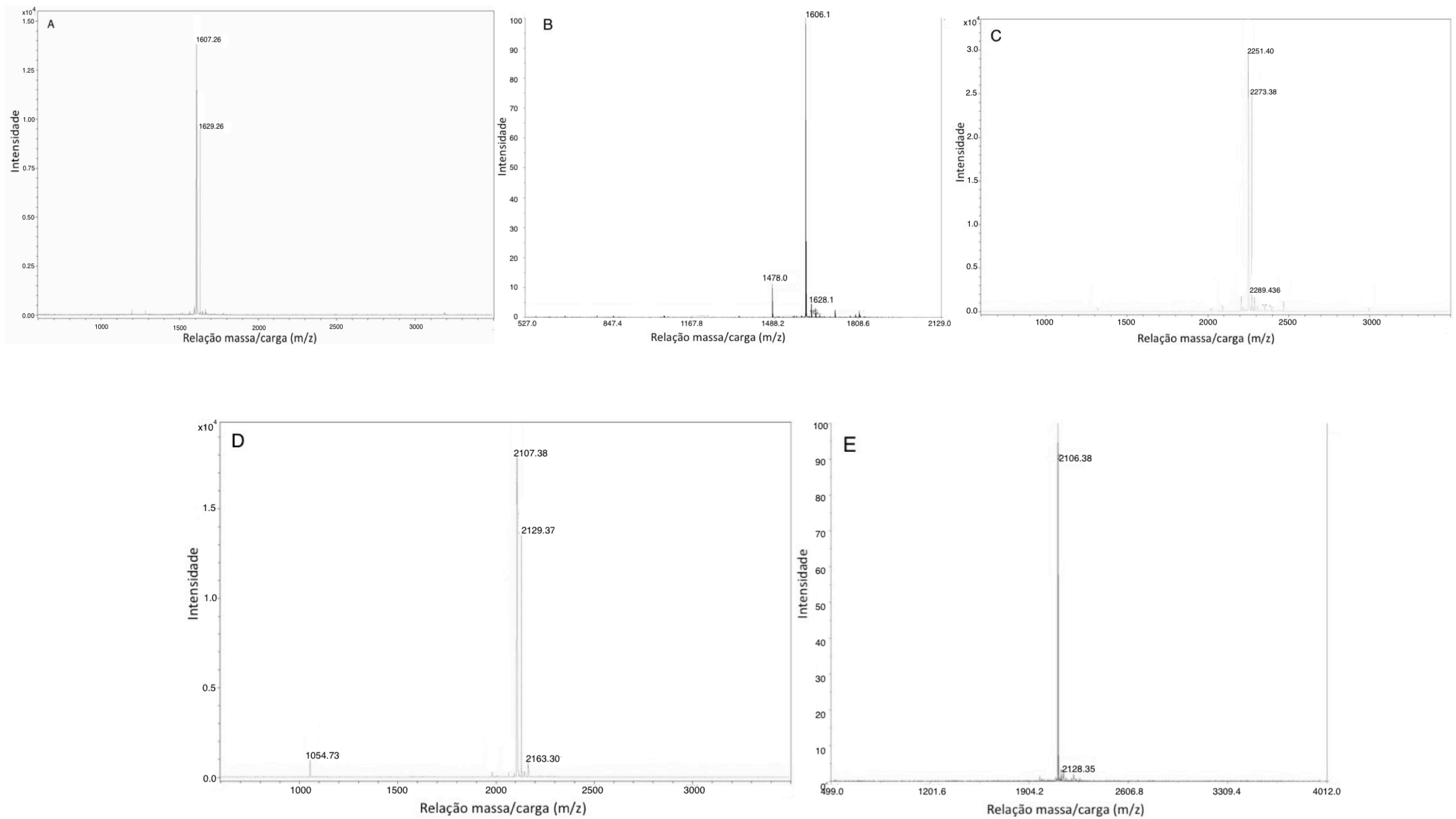

Figura 8. Espectros de massas gerados no equipamento MALDI-ToF, para os peptídeos sintéticos (A) $\left[I^{5}, R^{8}\right]$ mastoparano; (B) $\left[I^{5}, R^{8}\right]$ mastoparano-amida; (C) EcDBS1R6; (D) PaDBS1R1 e (E) PaDBS1R1-amida. 


\section{Parte 1: Estudo estrutural e funcional do análogo $\left[I^{5}, R^{8}\right]$ mastoparano}

\subsection{Espectro de atividade antimicrobiana}

A atividade antimicrobiana do $\left[\mathrm{I}^{5}, \mathrm{R}^{8}\right]$ MP foi avaliada contra uma grande variedade de cepas bacterianas e fúngicas. Como indicado na Tabela 5 , o peptídeo $\left[\mathrm{I}^{5}, \mathrm{R}^{8}\right]$ MP demonstrou uma potente atividade contra bactérias Gram-positivas e negativas, assim como contra as duas cepas de Candida sp. testadas (valores CMI no intervalo 3,125 - 25 $\mu \mathrm{M})$. Este peptídeo, no entanto, demonstrou pouca atividade contra $L$. ivanovii $(\mathrm{CMI}=50$ $\mu \mathrm{M})$ e foi inativo contra E. faecalis (CMI superior a $100 \mu \mathrm{M})$. Com o intuito de avaliar a influência da amidação C-terminal na sequência de $\left[\mathrm{I}^{5}, \mathrm{R}^{8}\right] \mathrm{MP}$, foram investigadas as potenciais mudanças na atividade antimicrobiana de $\left[\mathrm{I}^{5}, \mathrm{R}^{8}\right] \mathrm{MP}$-amida. Quando amidado no C-terminal, a atividade antimicrobiana do $\left[\mathrm{I}^{5}, \mathrm{R}^{8}\right] \mathrm{MP}$ aumentou comparada à atividade do peptídeo não amidado, sendo duas vezes melhor contra a bactéria Gram-negativa $K$. pneumoniae $(\mathrm{CMI}=3,125 \mu \mathrm{M})$ e quatro vezes melhor contra a bactéria Gram-positiva $S$. aureus $(\mathrm{CMI}=6,25 \mu \mathrm{M})\left(\right.$ Tabela 5). É interessante destacar que o $\left[\mathrm{I}^{5}, \mathrm{R}^{8}\right] \mathrm{MP}$-amida demonstrou ser altamente potente $(\mathrm{CMI}=3,125 \mu \mathrm{M})$ contra as cepas resistentes aos antibióticos, tais como KPC e MRSA. 
Tabela 5. Espectro de atividades antimicrobiana e citotóxica de $\left[I^{5}, R^{8}\right]$ mastoparano e $\left[I^{5}, R^{8}\right]$ mastoparano-amida.

\begin{tabular}{lcc}
\hline Microrganismo & \multicolumn{2}{c}{ Concentração Mínima Inibitória } \\
$(\boldsymbol{\mu M})$
\end{tabular}

${ }^{a}$ : Não testado. Concentração mínima inibitória (CMI) e concentração lítica $50\left(\mathrm{LC}_{50}\right)$,

expressas como valores médios de 3 experimentos independentes realizados em triplicata.

\subsection{Atividade hemolítica e citotóxica sobre linhagens celulares humanas}

Conforme indicado na Tabela 5, a atividade hemolítica de $\left[\mathrm{I}^{5}, \mathrm{R}^{8}\right] \mathrm{MP}$, investigada utilizando eritrócitos humanos, indicou que o peptídeo não apresentou efeito hemolítico significativo $\left(\mathrm{LC}_{50}>200 \mu \mathrm{M}\right)$. Afim de avaliar a viabilidade de células humanas após incubação com $\left[\mathrm{I}^{5}, \mathrm{R}^{8}\right] \mathrm{MP}$, o ensaio colorimétrico MTT foi realizado com macrófagos derivados de monócitos THP-1 e células embrionárias do rim HEK-293. Os resultados foram expressos por $\mathrm{LC}_{50}$ (concentração de peptídeo que causa $50 \%$ de morte celular) e indicaram que não há efeito citotóxico de $\left[\mathrm{I}^{5}, \mathrm{R}^{8}\right]$ MP contra as células HEK-293 $\left(\mathrm{LC}_{50}>\right.$ $200 \mu \mathrm{M})$. Por outro lado, o peptídeo exibiu citotoxicidade frente às células THP-1, apresentando um valor menor de $\operatorname{LC}_{50}(24,5 \pm 12,9 \mu \mathrm{M})$. Os resultados contidos na Tabela 5, sugerem que $\left[\mathrm{I}^{5}, \mathrm{R}^{8}\right]$ MP não apresenta citotoxicidade em concentrações 
correspondentes à CMI para bactérias Gram-negativas, bactérias resistentes, S. pyogenes e C. albicans.

\subsection{Permeabilização e despolarização da membrana bacteriana}

$\mathrm{O}$ efeito de $\left[\mathrm{I}^{5}, \mathrm{R}^{8}\right]$ MP sobre a integridade das membranas citoplasmáticas bacterianas foi investigado para a bactéria Gram-negativa E. coli ATCC 25922 e a bactéria Gram-positiva S. aureus ATCC 25923, como cepas de referência, utilizando concentrações de peptídeo correspondentes a 2 vezes o valor da CMI $(25$ e $50 \mu \mathrm{M}$, respectivamente).

A capacidade de $\left[\mathrm{I}^{5}, \mathrm{R}^{8}\right]$ MP de alterar a permeabilidade da membrana, foi avaliada através do estudo de fluorescência SYTOX Green (SG), uma sonda de alta afinidade pelos ácidos nucleicos, impermeável às membranas citoplasmáticas intactas. Quando a membrana citoplasmática consegue ser alterada, a sonda SG penetra à célula e permite detectar um aumento da fluorescência quando a ligada aos ácidos nucleicos. A Figura 9 permite observar a habilidade de $\left[\mathrm{I}^{5}, \mathrm{R}^{8}\right]$ MP para permeabilizar a membrana citoplasmática de ambas cepas bacterianas testadas, E. coli e S. aureus, como indicado pelo aumento da fluorescência de SG comparado com o controle negativo (PBS) e o controle positivo (melitina). Observa-se que a permeabilização da membrana de S. aureus (Figura 9B) induzida por $\left[\mathrm{I}^{5}, \mathrm{R}^{8}\right]$ MP foi mais rápida e potente comparada com aquela de E. coli (Figura 9A) apresentando um maior valor máximo de permeabilização (máxima fluorescência).

A atividade de despolarização da membrana citoplasmática bacteriana induzida por $\left[\mathrm{I}^{5}, \mathrm{R}^{8}\right] \mathrm{MP}$, também foi avaliada para E. coli e $S$. aureus. Para isto, foi utilizada a sonda fluorescente DiSC3(5), que permite detectar mudanças na emissão de fluorescência quando o potencial de membrana sofre alterações. A Figura 9 ilustra o valor mínimo de 
fluorescência que indica a acumulação da sonda DiSC3(5) na bicamada lipídica. Após a incubação com o controle positivo melitina, que induz a perda do potencial de membrana, observa-se o aumento da fluorescência devido à liberação da sonda ao meio. Quando as células bacterianas foram incubadas com $\left[\mathrm{I}^{5}, \mathrm{R}^{8}\right] \mathrm{MP}$, observou-se uma rápida $(<5 \mathrm{~min})$ despolarização em ambas as cepas E. coli (Figura 9C) e S. aureus (Figura 9D), com eficiências maiores que o peptídeo controle melitina. 

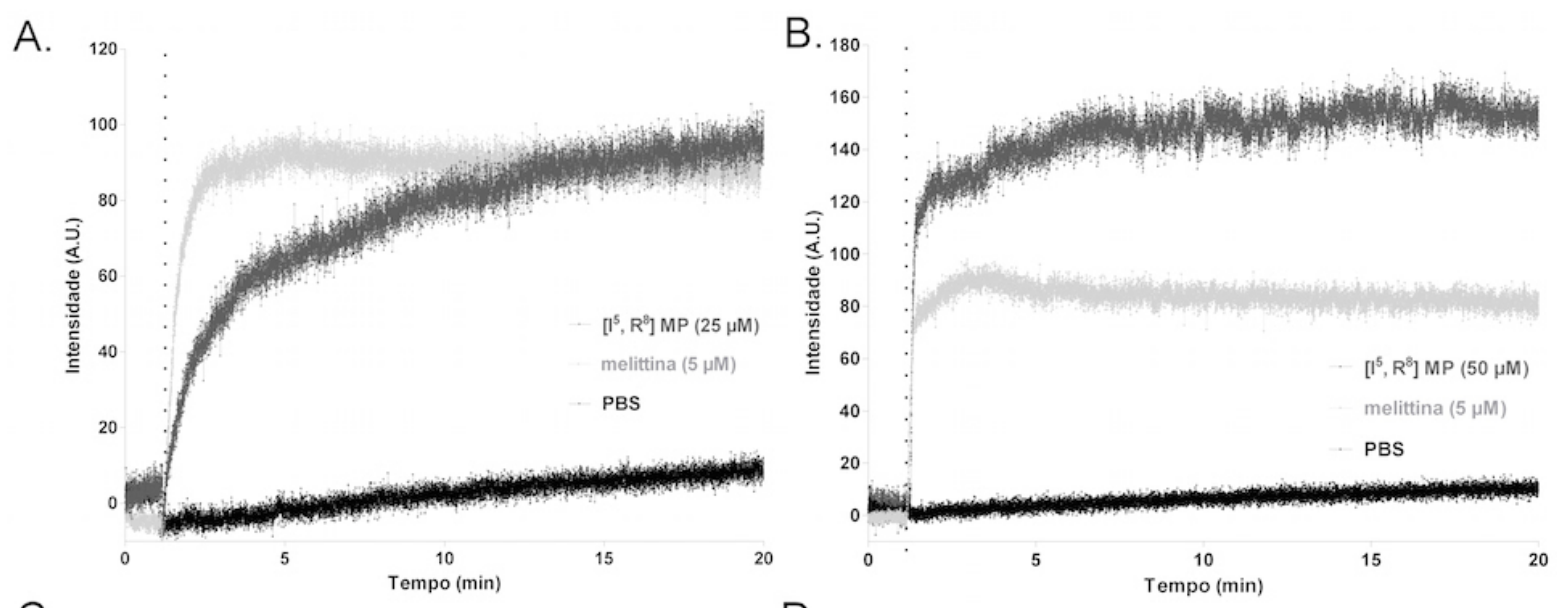

C.

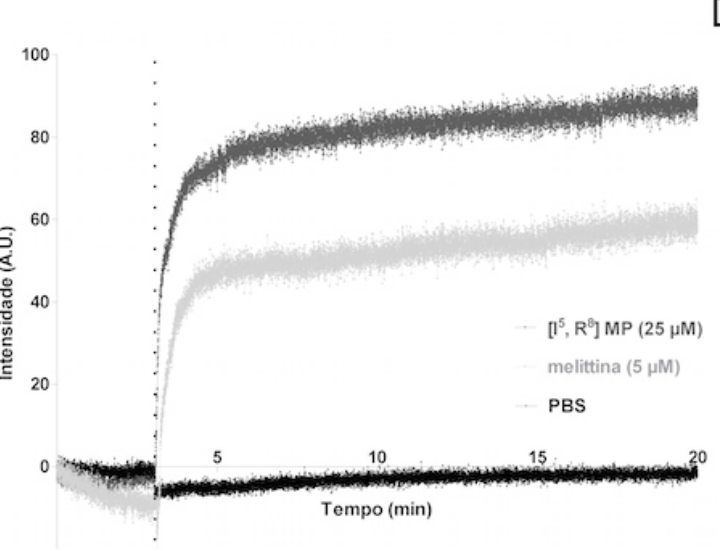

D.

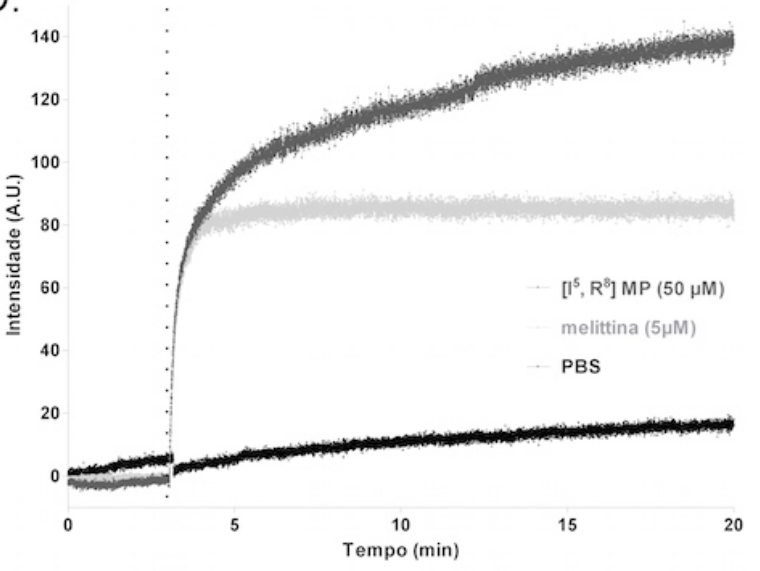

Figura 9. Efeito de $\left[\mathrm{I}^{5}, \mathrm{R}^{8}\right]$ MP sobre a integridade da membrana plasmática de $E$. coli ATCC 25922 e S. aureus ATCC 25923. Cinética da emissão de fluorescência da sonda (A, B) SYTOX Green e (C, D) $\operatorname{DiSC} 3(5)$ em função do tempo, após adição de peptídeo (linha pontilhada vertical). Permeabilização da membrana citoplasmática de $E$. coli $\mathbf{( A )}$ e $S$. aureus $(\mathbf{B})$ induzida por $\left[\mathrm{I}^{5}, \mathrm{R}^{8}\right] \mathrm{MP}$ na concentração correspondente à 2 vezes o valor da CMI $(25$ e $50 \mu \mathrm{M}$, respectivamente). Despolarização induzida por $\left[\mathrm{I}^{5}, \mathrm{R}^{8}\right] \mathrm{MP}$ (mesma concentração) sobre a membrana citoplasmática de E. coli (C) e S. aureus (D). O controle negativo corresponde as células bacterianas incubadas em PBS na ausência do peptídeo, enquanto o controle positivo corresponde à incubação com $5 \mu \mathrm{M}$ de melitina. 


\subsection{Cinética da atividade antibacteriana in vitro}

O tempo que o peptídeo leva para produzir seu efeito letal, foi determinado em testes contra as bactérias de referência Gram-negativa e Gram-positiva, em concentrações de $\left[\mathrm{I}^{5}, \mathrm{R}^{8}\right]$ MP idênticas às utilizadas nos ensaios de permeabilização e despolarização $(25 \mu \mathrm{M}$ para $E$. coli e $50 \mu \mathrm{M}$ para $S$. aureus). A cinética de morte celular pode ser analisada mediante as curvas de morte na Figura 10. Assim, $\left[\mathrm{I}^{5}, \mathrm{R}^{8}\right]$ MP inibiu o crescimento de $E$. coli a partir dos 15 min de exposição da bactéria ao peptídeo, enquanto o tempo necessário para produzir o mesmo efeito contra $S$. aureus foi de 45 min. Consequentemente, $\left[\mathrm{I}^{5}, \mathrm{R}^{8}\right] \mathrm{MP}$ apresentou uma velocidade de ação maior contra a bactéria Gram-negativa comparado com a Gram-positiva. As curvas de morte indicaram um efeito bactericida de $\left[\mathrm{I}^{5}, \mathrm{R}^{8}\right] \mathrm{MP}$ para ambas cepas bacterianas.

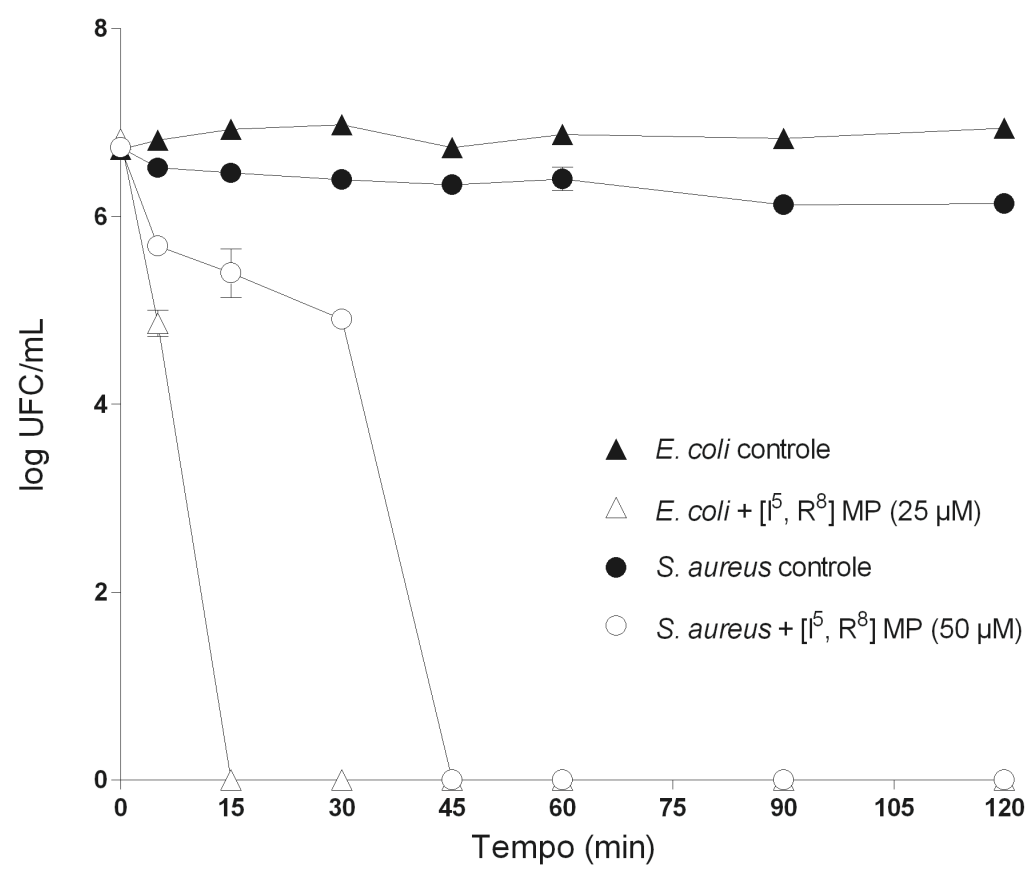

Figura 10. Cinética da morte celular de E. coli ATCC 25922 (triângulos brancos) e S. aureus ATCC 25923 (ćŕrculos brancos) após incubação com $25 \mu \mathrm{M}$ e $50 \mu \mathrm{M}$ de $\left[\mathrm{I}^{5}, \mathrm{R}^{8}\right] \mathrm{MP}$, respectivamente (dobro da CMI). O controle foi realizado em ausência de peptídeo. Os resultados são expressos como a média dos valores representativos de um experimento realizado em triplicata. 


\subsection{Visualização da atividade antimicrobiana por MEV-FEG}

As imagens tomadas pela técnica MEV-FEG permitiram visualizar o efeito de $\left[\mathrm{I}^{5}, \mathrm{R}^{8}\right] \mathrm{MP}$ sobre a morfologia da superfície dos microrganismos sensíveis $P$. aeruginosa ATCC 27853, $L$. ivanovii Li 4pVS2 e C. albicans ATCC 90028. Dessa forma, foi possível monitorar alterações morfológicas nas células e obter detalhes sobre o mecanismo de ação do peptídeo nas concentrações letais para os microrganismos em estudo. Conforme pode ser visto na Figura 11, as imagens MEV-FEG de alta resolução mostram que todas as células apresentaram danos após incubação com o peptídeo $\left[\mathrm{I}^{5}, \mathrm{R}^{8}\right] \mathrm{MP}$, em comparação com as células controle (crescendo em ausência de peptídeo). A potente atividade de $\left[\mathrm{I}^{5}, \mathrm{R}^{8}\right] \mathrm{MP}$ contra a bactéria Gram-negativa $P$. aeruginosa, foi confirmada pela observação de numerosas células lisadas e detritos que estariam indicando um extravasamento do material citoplasmático, na presença do peptídeo nas concentrações correspondentes à CMI $(6,25 \mu \mathrm{M})$ (Figura 11B) e duas vezes acima da CMI (12,5 $\mu \mathrm{M})$ (Figura 11C), quando comparada com as células controle (Figura 11A). No caso da bactéria Gram-positiva L. ivanovii, as imagens de microscopia mostram danos severos na membrana e extravasamento do material intracelular quando as células cresceram em presença de $50 \mu \mathrm{M}\left[\mathrm{I}^{5}\right.$, $\left.\mathrm{R}^{8}\right] \mathrm{MP}(\mathrm{CMI})$ (Figura 11E) e de $100 \mu \mathrm{M}\left[\mathrm{I}^{5}, \mathrm{R}^{8}\right] \mathrm{MP}$ (Figura 11F), se comparamos com as células controle (Figura 11D). Ao comparar as imagens das células controle de C. albicans (Figura $11 \mathrm{G}$ ) e aquelas incubadas com 12,5 $\mu \mathrm{M}$ de $\left[\mathrm{I}^{5}, \mathrm{R}^{8}\right] \mathrm{MP}$ (CMI; Figura 11H), observam-se alterações morfológicas significativas entre estas células, definidas por deformações na membrana e colapso, encontrando-se células de estrutura achatada. Esses efeitos constatam-se claramente nas células $C$. albicans incubadas com uma concentração de $\left[\mathrm{I}^{5}, \mathrm{R}^{8}\right] \mathrm{MP}$ correspondente à 2 vezes a CMI $(25 \mu \mathrm{M}$; Figura 11I). 

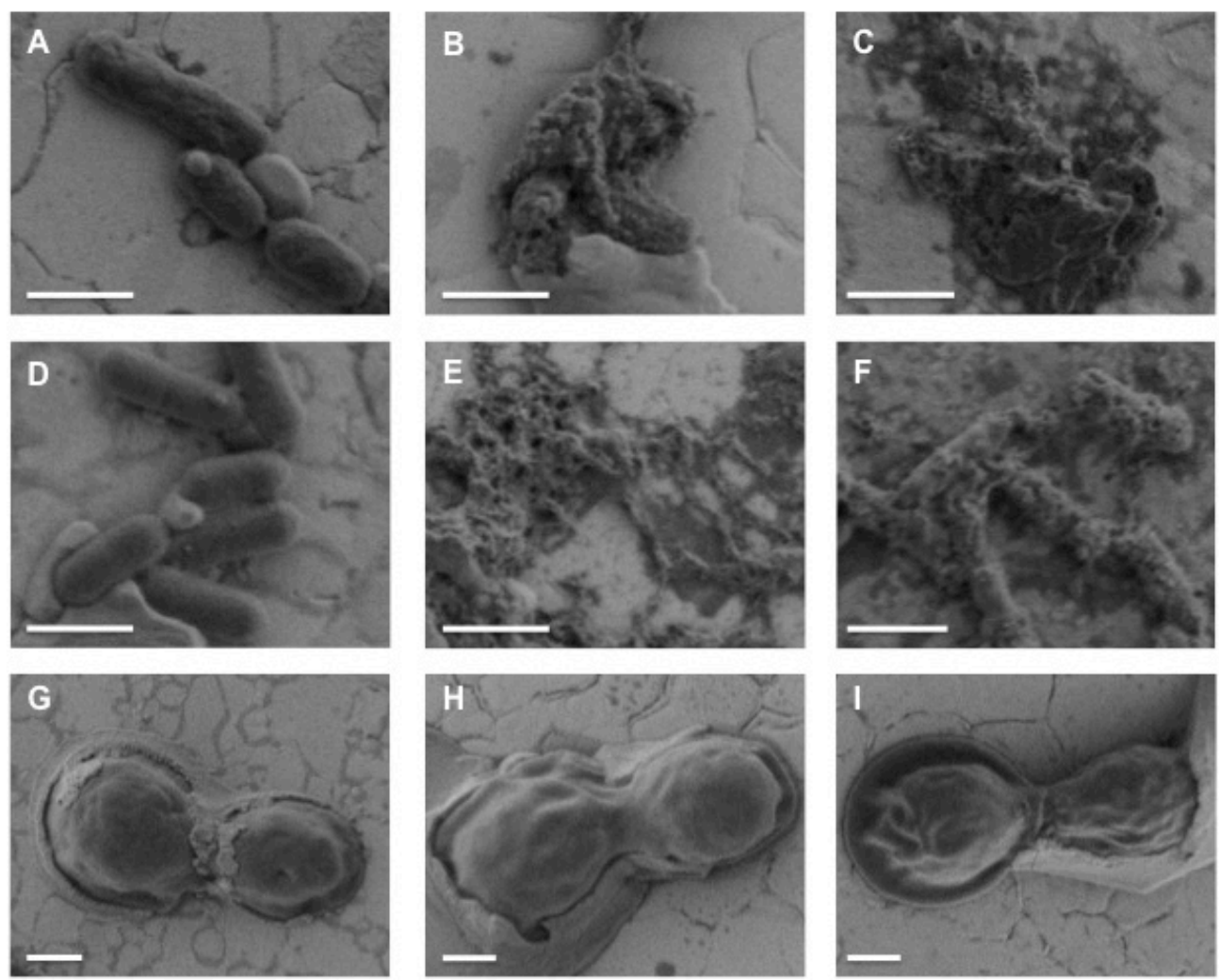

Figura 11. Imagens obtidas por MEV-FEG do efeito de $\left[\mathrm{I}^{5}, \mathrm{R}^{8}\right]$ MP sobre as células de (A-C) $P$. aeruginosa ATCC 27853, (D-F) L. ivanovii Li 4pVS2 e (G-I) C. albicans ATCC 90028. (A, D, G) Células controle, na ausência de $\left[\mathrm{I}^{5}, \mathrm{R}^{8}\right]$ MP. (B, C) P. aeruginosa incubadas com $6,25 \mu \mathrm{M}\left[\mathrm{I}^{5}, \mathrm{R}^{8}\right] \mathrm{MP}$ (CMI) e $12,5 \mu \mathrm{M}$, respectivamente. (E, F) L. ivanovii incubadas com $50 \mu \mathrm{M}\left[\mathrm{I}^{5}, \mathrm{R}^{8}\right] \mathrm{MP}(\mathrm{CMI})$ e 100 $\mu \mathrm{M}$, respectivamente. (H, I) C. albicans incubadas com $12,5 \mu \mathrm{M}\left[\mathrm{I}^{5}, \mathrm{R}^{8}\right]$ MP (CMI) e $25 \mu \mathrm{M}$, respectivamente. Barra $=1 \mu \mathrm{m}$.

\subsection{Análise in silico da estrutura tridimensional e interação com membrana DOPC}

A modelagem molecular de $\left[\mathrm{I}^{5}, \mathrm{R}^{8}\right]$ MP indicou que o peptídeo adota uma estrutura de $\alpha$ hélice (Figura 12A), com uma segregação entre os aminoácidos carregados e hidrofóbicos (como indicado pelo diagrama de projeção de hélice da Figura 6). Em ambiente aquoso, foi observado que ambas as estruturas de $\left[\mathrm{I}^{5}, \mathrm{R}^{8}\right] \mathrm{MP}$ e de $\left[\mathrm{I}^{5}, \mathrm{R}^{8}\right] \mathrm{MP}$-amida, tendem a desenovelar-se (Figura 12C). Durante a simulação, o desvio da raiz quadrada média (RMSD) de $\left[\mathrm{I}^{5}, \mathrm{R}^{8}\right] \mathrm{MP}$ mostrou uma variação entre 2-7 $\AA$, enquanto que para $\left[\mathrm{I}^{5}, \mathrm{R}^{8}\right] \mathrm{MP}$-amida, a variação foi de cerca de $2-6$ $\AA$ (Figura 12B). A partir dos dados de flutuação RMS dos resíduos, observou-se que para $\left[\mathrm{I}^{5}, \mathrm{R}^{8}\right]$ MP-amida, o porção N-terminal foi mais estável do que a porção C-terminal, enquanto que para 
$\left[\mathrm{I}^{5}, \mathrm{R}^{8}\right]$ MP a totalidade da estrutura mostrou um comportamento semelhante (Figura 12E). Em contrapartida, $\left[\mathrm{I}^{5}, \mathrm{R}^{8}\right] \mathrm{MP}$ em contato com a bicamada DOPC, apresentou pouca variação de estrutura (Figura 12D), sendo RMSD de cerca de $1 \AA$ (Figura 12B), o que reflete-se na flutuação RMS dos resíduos (abaixo de 1,5 ^) (Figura 12E).

A)

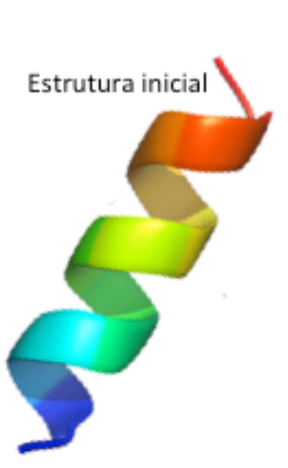

D)

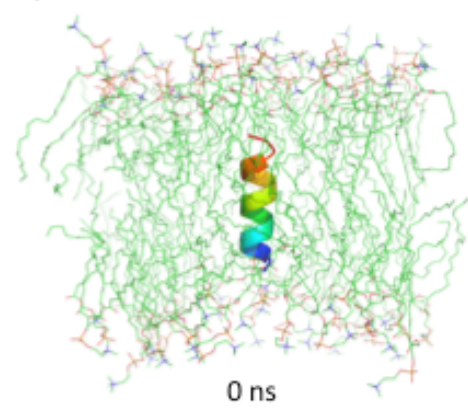

B)

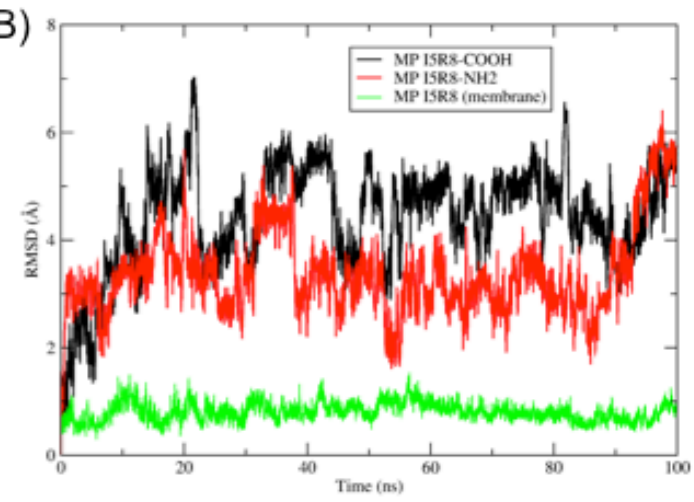

C)

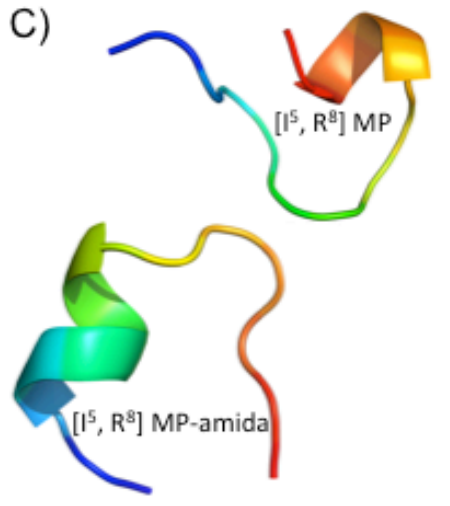

E)

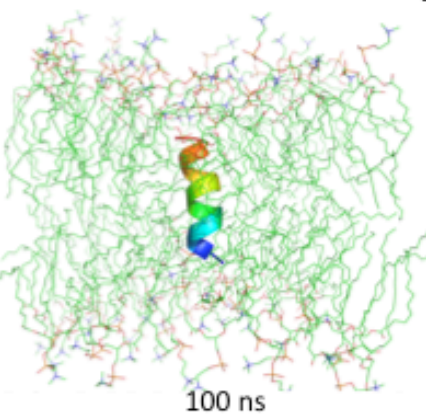

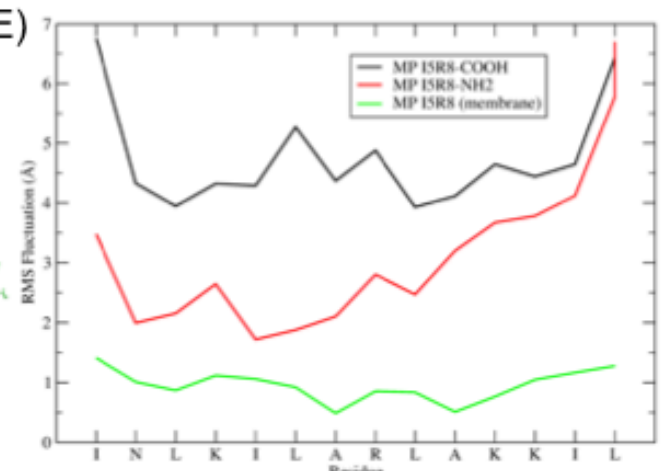

Figura 12. Predição da estrutura tridimensional de $\left[\mathrm{I}^{5}, \mathrm{R}^{8}\right]$ mastoparano. (A) Modelagem molecular de $\left[\mathrm{I}^{5}, \mathrm{R}^{8}\right]$ MP. A estrutura apresenta valores DOPE Score de -981.4 e Z-Score em PROSA de -2.15 , com todos os resíduos em regiões favoráveis de Ramachandram Plot. A região N-terminal está representada em azul, e C-terminal em vermelho. (B) Evolução de RMSD através da simulação. (C) Estruturas finais de $\left[\mathrm{I}^{5}, \mathrm{R}^{8}\right]$ MP e de $\left[\mathrm{I}^{5}, \mathrm{R}^{8}\right]$ MP-amida após $100 \mathrm{~ns}$ de simulação. (D) Posições inicial a $0 \mathrm{~ns}$ (esquerda) e posição final após $100 \mathrm{~ns}$ de simulação (direita) da interação do peptídeo $\left[\mathrm{I}^{5}, \mathrm{R}^{8}\right] \mathrm{MP}$ com membrana DOPC. (E) Flutuação RMS para cada resíduo de $\left[\mathrm{I}^{5}, \mathrm{R}^{8}\right]$ MP durante as simulações (Irazazabal et al., 2016). 


\section{Parte 2: Estudo estrutural e funcional do peptídeo desenhado EcDBS1R6}

\subsection{Espectro de atividade antimicrobiana}

A atividade antimicrobiana de EcDBS1R6 foi avaliada para bactérias e fungos. A Tabela 6 indica que EcDBS1R6 demonstrou uma potente atividade contra as bactérias Gram-negativas, com valores de CMI no intervalo 3,125 - 6,25 $\mu \mathrm{M}$. No caso das bactérias Gram-positivas, EcDBS1R6 apresentou valores de CMI maiores, no intervalo 3,125 - $25 \mu \mathrm{M}$, com exceção de $E$. faecalis, para a qual o peptídeo não demonstrou atividade (MIC superior a $100 \mu \mathrm{M}$ ). Não foi observada atividade frente as espécies de fungo testadas, para as quais EcDBS1R6 apresentou valores de CMI igual a $100 \mu \mathrm{M}$.

Tabela 6. Espectro de atividades antimicrobiana e citotóxica de EcDBS1R6.

\begin{tabular}{lc}
\hline Microrganismo & $\begin{array}{c}\text { Concentração Mínima Inibitória } \\
(\boldsymbol{\mu M}) \mathbf{d e ~ E c D B S 1 R 6}\end{array}$ \\
\hline Bactérias Gram-negativas & 3,125 \\
Escherichia coli ATCC 25922 & 6,25 \\
Pseudomonas aeruginosa ATCC 27853 & 3,125 \\
Klebsiella pneumoniae ATCC 13883 & 3,125 \\
Acinetobacter baumannii ATCC 19606 & 3,125 \\
\hline Bactéria Gram-positivas & 25 \\
Staphylococcus aureus ATCC 25923 & 12,5 \\
Streptococcus pyogenes ATCC 19615 & $>100$ \\
Listeria ivanovii Li 4pVS2 & 100 \\
Enterococcus faecalis ATCC 29212 & 100 \\
\hline Fungos & Concentração Lítica 50 $(\boldsymbol{\mu M})$ \\
Candida albicans ATCC 90028 & $5,1 \pm 1,1$ \\
Candida parapsilosis ATCC 22019 & $111,0 \pm 27,2$ \\
\hline Células humanas & $>200$ \\
\hline Macrófagos derivados de monócitos THP-1 & \\
HEK-293 & \\
Eritrócitos & \\
\hline
\end{tabular}

${ }^{a}$ : Não determinado. Concentração mínima inibitória (CMI) e concentração lítica $50\left(\mathrm{LC}_{50}\right)$, expressas como valores médios de 3 experimentos independentes realizados em triplicata.

\subsection{Atividade hemolítica e citotóxica sobre linhagens celulares humanas}

Conforme os dados da Tabela 6 , não foi detectada atividade hemolítica do peptídeo EcDBS1R6 contra eritrócitos humanos $\left(\mathrm{LC}_{50}>200 \mu \mathrm{M}\right)$. A atividade citotóxica de EcDBS1R6 
foi avaliada pelo ensaio colorimétrico MTT frente as células humanas: macrófagos derivados de monócitos THP-1 e células embrionárias do rim HEK-293. Os resultados, expostos na Tabela 6 e expressos em valores $\mathrm{LC}_{50}$ indicaram que EcDBS1R6 não possui citotoxicidade frente as células HEK-293 $\left(\mathrm{LC}_{50}=111,1 \pm 27,2 \mu \mathrm{M}\right)$, apresentado efeito citotóxico frente as células THP-1 para as quais a concentração $\mathrm{LC}_{50}$ foi inferior aos valores de CMIs determinados para as bactérias testadas $\left(\mathrm{LC}_{50}=5,1 \pm 1,1 \mu \mathrm{M}\right)$.

\subsection{Permeabilização e despolarização da membrana bacteriana}

Utilizando as cepas de referência E. coli ATCC 25922 e $S$. aureus ATCC 25923, a capacidade de EcDBS1R6 de afetar a integridade das membranas citoplasmáticas bacterianas foi investigada para concentrações equivalentes ao dobro da CMI $(6,25 \mu \mathrm{M})$. Para isto, a permeabilidade e a despolarização das membranas após incubação com o peptídeo, foram avaliadas pela cinética da intensidade de fluorescência em função do tempo das sondas SG e DiSC3(5), respectivamente. Na Figura 13, observa-se que EcDBS1R6 foi capaz de permeabilizar a membrana citoplasmática de ambas bactérias Gram-negativa E. coli (Figura 13A) e Grampositiva $S$. aureus (Figura 13B), quando comparada com o controle (bactérias em PBS, na ausência de peptídeo). No caso de E. coli, a permeabilização induzida por EcDBS1R6 atingiu o máximo valor de fluorescência SG após um curto intervalo de tempo (5 min), e foi tão eficaz quanto à induzida por melitina (controle positivo). Para S. aureus, observou-se uma permeabilização instantânea da membrana, com um sinal de fluorescência SG máximo, menor do que o controle positivo.

A Figura 13 mostra também o efeito de EcDBS1R6 sobre o potencial da membrana, indicando uma despolarização induzida pelo peptídeo para ambas bactérias E. coli (Figura 13C) e S. aureus (Figura 13D), como pode ser observado pelo aumento da fluorescência da sonda DiSC3(5) em comparação com o controle negativo (PBS). Para ambas as células bacterianas, a 
despolarização induzida aconteceu de forma rápida e atingiu intensidades máximas de fluorescência DiSC3(5) semelhantes às do controle positivo melitina.
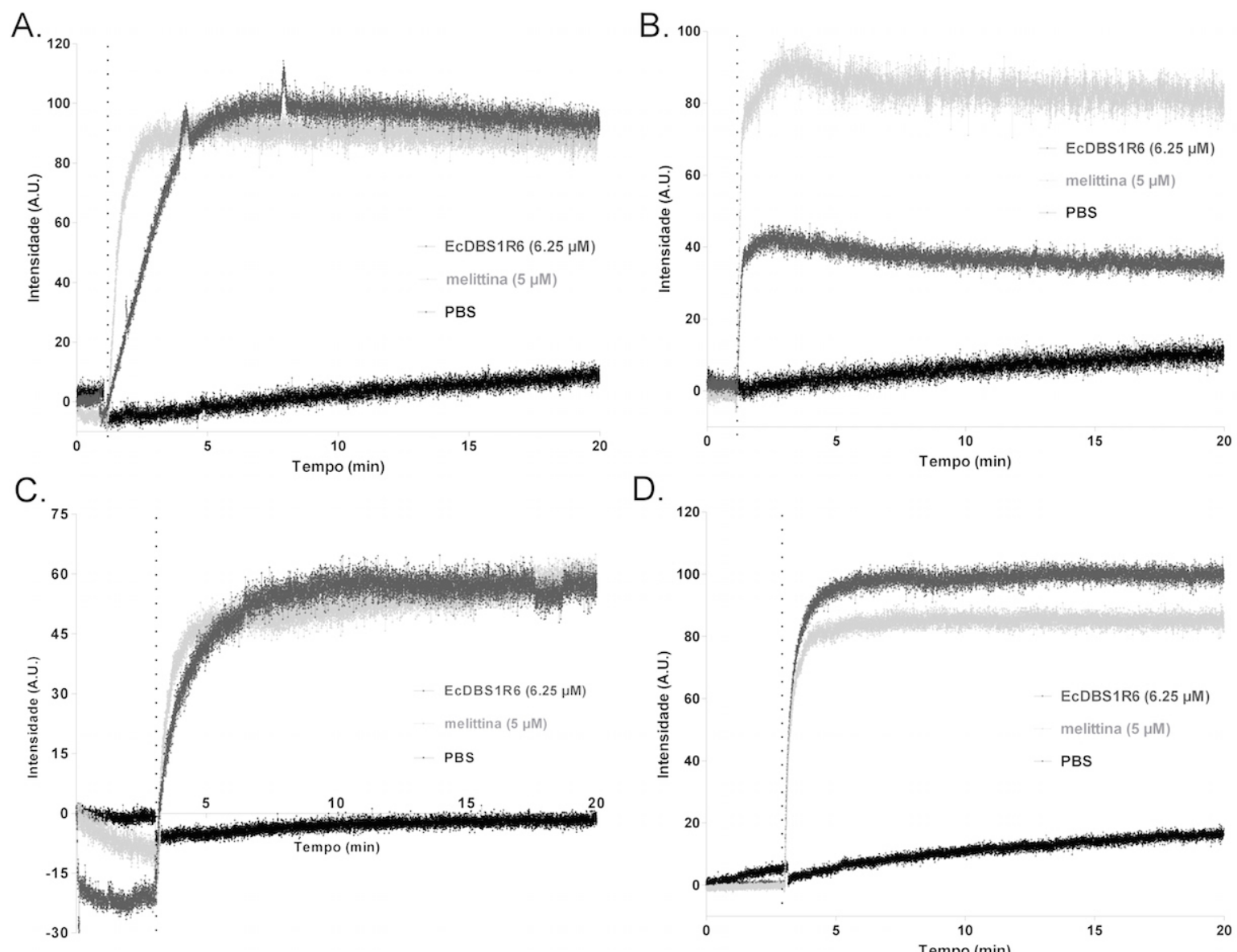

D.

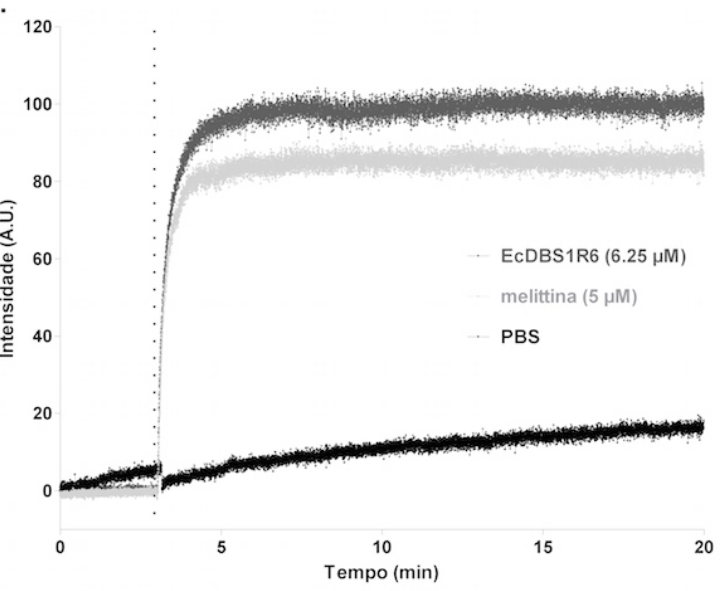

Figura 13. Efeito de EcDBS1R6 sobre a integridade da membrana plasmática de E. coli ATCC 25922 e S. aureus ATCC 25923. Cinética da emissão de fluorescência da sonda (A, B) SYTOX Green e (C, D) DiSC3(5) em função do tempo, após adição de peptídeo (linha pontilhada vertical). Permeabilização da membrana citoplasmática de E. coli (A) e S. aureus (B) induzida por EcDBS1R6 na concentração correspondente à 2 vezes o valor da CMI $(6,25 \mu \mathrm{M})$. Despolarização induzida por EcDBS1R6 (mesma concentração) sobre a membrana citoplasmática de E. coli (C) e S. aureus (D). O controle negativo corresponde as células bacterianas incubadas em PBS na ausência do peptídeo, enquanto o controle positivo corresponde à incubação com $5 \mu \mathrm{M}$ de melitina. 


\subsection{Cinética da atividade antibacteriana in vitro}

A velocidade de ação de EcDBS1R6 foi investigada para E. coli e $S$. aureus na concentração de peptídeo duas vezes acima da CMI $(6,25 \mu \mathrm{M})$, concentração idêntica à utilizada nos ensaios de permeabilização e despolarização. Os resultados obtidos, representados pelas curvas de morte da Figura 14, indicaram que o tempo necessário para EcDBS1R6 produzir a morte de ambas cepas bacterianas sensíveis foi de 15 min.

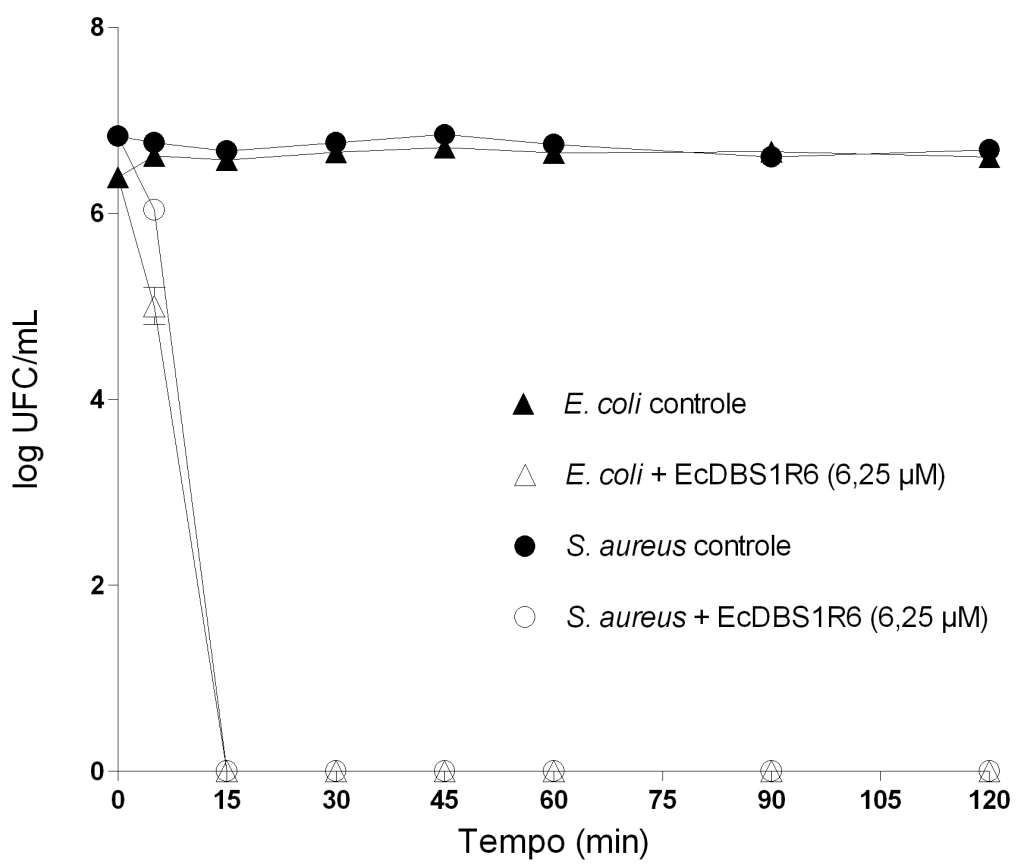

Figura 14. Cinética da morte celular de E. coli ATCC 25922 (triângulos brancos) e $S$. aureus ATCC 25923 (círculos brancos) após incubação com 6,25 $\mu \mathrm{M}$ de EcDBS1R6 (dobro da CMI). O controle foi realizado em ausência de peptídeo. Os resultados são expressos como a média dos valores representativos de um experimento realizado em triplicata.

\subsection{Visualização da atividade antimicrobiana por MEV-FEG}

Na Figura 15, visualizam-se as imagens feitas mediante MEV-FEG para investigar o efeito de EcDBS1R6 sobre a morfologia da superfície das bactérias sensíveis $P$. aeruginosa ATCC 27853 e L. ivanovii Li 4pVS2. De acordo com as análises microscópicas das amostras, observou-se que as células bacterianas $P$. aeruginosa e $L$. 
ivanovii, crescendo na presença de EcDBS1R6, apresentaram danos na membrana, quando comparadas com as células controle.

No caso de $P$. aeruginosa, confirmou-se a potente atividade do peptídeo ao observar uma deformação da membrana das células bacterianas na presença de 6,25 $\mu \mathrm{M}$ EcDBS1R6 (CMI) (Figura 15B), quando comparadas com a célula controle (Figura 15A). Além disso, ao aumentar a concentração de peptídeo utilizada na incubação, foi possível notar células de $P$. aeruginosa com alterações significativas na presença de $12,5 \mu \mathrm{M}$ EcDBS1R6 (dobro da CMI) (Figura 15C) e, ainda de forma mais evidente, na presença de $50 \mu \mathrm{M}$ EcDBS1R6 (8 vezes acima da CIM) observou-se o colapso da membrana e a formação de poros nas células (Figura 15D).

No caso de L. ivanovii, a Figura 15F revela que as células crescidas na presença de $25 \mu \mathrm{M}$ EcDBS1R6 (dobro da CMI) sofreram deformações na membrana plasmática, observando-se a formação de poros, quando comparada com a membrana plasmática intata das células controle (Figura 15E). 

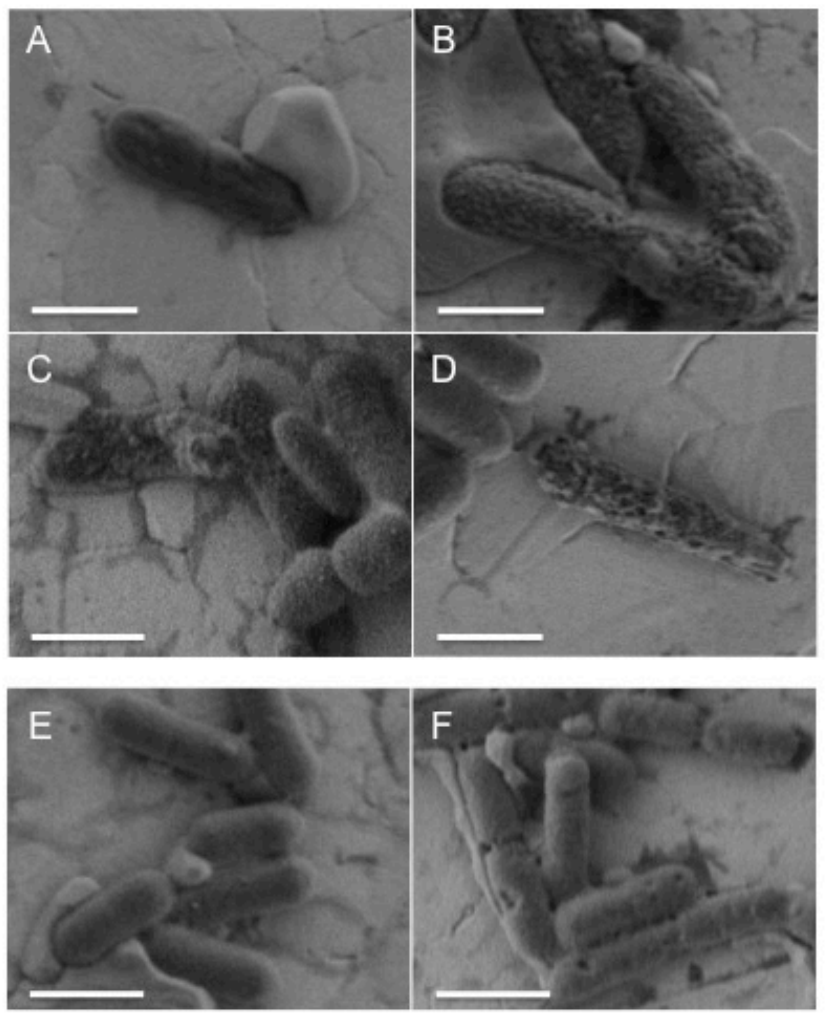

Figura 15. Imagens obtidas por MEV-FEG do efeito de EcDBS1R6 sobre as células de (A-D) $P$. aeruginosa ATCC 27853 e (E, F) L. ivanovii Li 4pVS2. (A, E) Células controle, na ausência de EcDBS1R6. (B, C e D) $P$. aeruginosa, incubadas com EcDBS1R6 nas concentrações $6,25 \mu \mathrm{M}$ (CMI), 12,5 $\mu \mathrm{M}$ (dobro da CMI) e $50 \mu \mathrm{M}$, respectivamente. (F) L. ivanovii incubadas com $25 \mu \mathrm{M}$ EcDBS1R6 (dobro da CMI). Barras $=1 \mu \mathrm{m}$.

\subsection{Análise in silico da estrutura tridimensional e interação com membrana DOPC}

A estrutura de EcDBS1R6 observada por meio da modelagem molecular indicou uma conformação de $\alpha$-hélice anfipática, como indicado pela Figura 16A (em concordância com o diagrama de projeção de hélice da Figura 7). Em ambiente aquoso, foi observado que a estrutura de EcDBS1R6 desenovela-se na porção C-terminal (Figura 16C). Durante a simulação em água, o desvio da raiz quadrada média (RMSD) mostrou uma variação de 6-8 $\AA$ (Figura 16B), enquanto a simulação em ambiente de membrana mostrou uma pequena variação, com valor de RMSD entre 2 e $3 \AA$ (Figura 16B). Os dados de flutuação RMS dos resíduos indicaram que, em ambiente de membrana, o peptídeo apresenta maior estabilidade na porção N-terminal do que a porção C-terminal com flutuação RMS dos resíduos de $4 \AA$. No caso da simulação em água, os resíduos da 
região C-terminal da estrutura apresentaram maior flutuação sendo uma variação RMS de $5 \AA$ (Figura 16E).

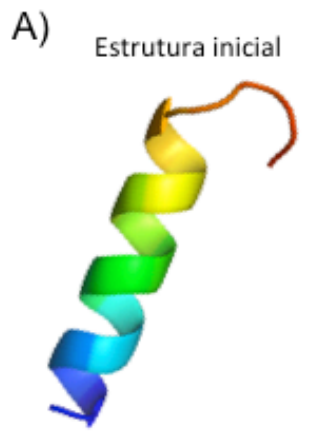

D)

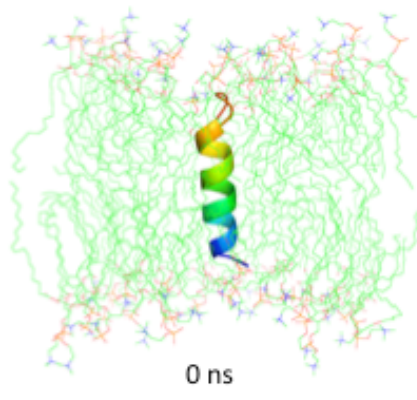

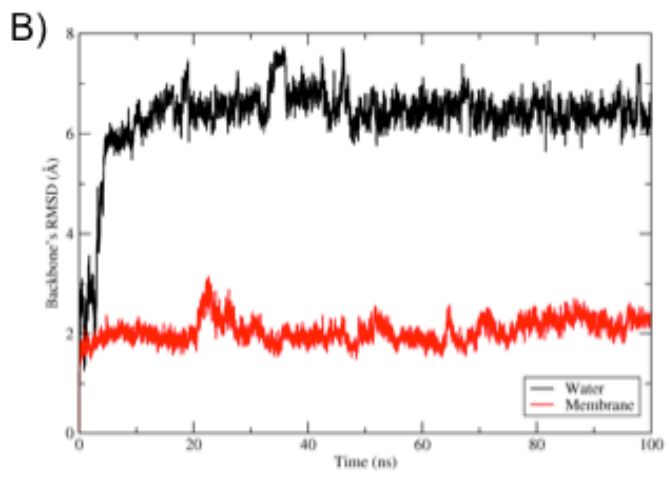

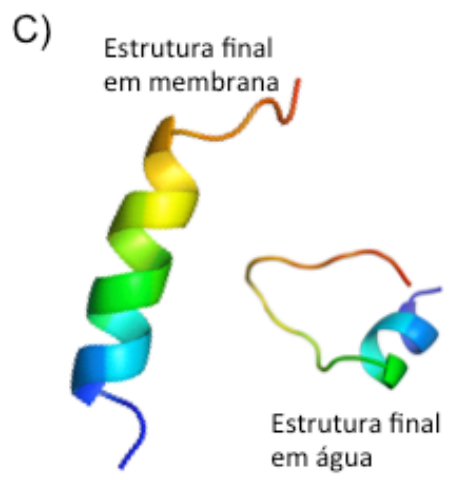

E)
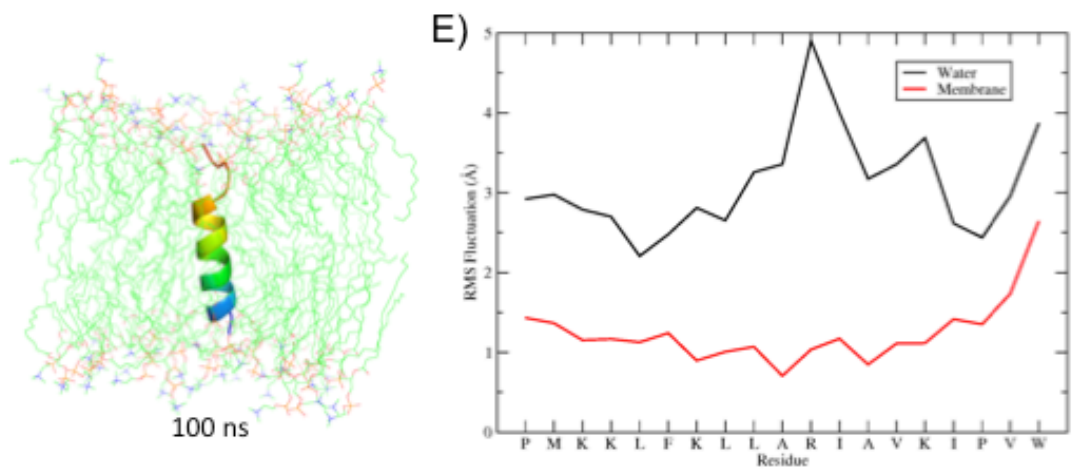

Figura 16. Predição da estrutura tridimensional de EcDBS1R6. (A) Modelagem molecular de EcDBS1R6. A estrutura apresenta valores DOPE Score de -1264.3 e Z-score em PROSA de -1.11, com todos os resíduos favoráveis de Ramachandram Plot. A região N-terminal está representada em azul, e C-terminal em vermelho. (B) Evolução de RMSD através da simulação. (C) Estruturas finais de EcDBS1R6 em membrana DOPC e em água, após $100 \mathrm{~ns}$ de simulação. (D) Posições inicial a 0 ns (esquerda) e final após $100 \mathrm{~ns}$ de simulação (direita) da interação do peptídeo EcDBS1R6 com a membrana DOPC. (E) Flutuação RMS para cada resíduo de EcDBS1R6 durante as simulações. 


\section{Parte 3: Estudo estrutural e funcional do peptídeo desenhado PaDBS1R1}

\subsection{Espectro de atividade antimicrobiana}

A ação antimicrobiana de PaDBS1R1 foi testada contra bactérias e fungos. Os resultados, expressos em termos de CMI, estão indicados na Tabela 7. O peptídeo PaDBS1R1 apresentou uma potente atividade contra um amplo espectro de bactérias Gram-negativas e positivas com baixos valores de CMI no intervalo de 1,5 - 3,125 $\mu \mathrm{M}$, com exceção da bactéria Gram-positiva E. faecalis para a qual, PaDBS1R1 apresentou baixa atividade $(\mathrm{CMI}=50 \mu \mathrm{M})$. Também, PaDBS1R1 mostrou atividade contra o fungo C. parapsilosis $(\mathrm{CMI}=25 \mu \mathrm{M})$, porém foi menos ativo contra a espécie C. albicans (CMI $\geq 50 \mu \mathrm{M})$.

Com o intuito de avaliar mudanças de atividade devido à amidação do C-terminal, foram investigadas as CMIs de PaDBS1R-amida para as bactérias Gram-negativa E. coli e P. aeruginosa, assim como para a bactéria Gram-positiva S. aureus. Para essas cepas, os valores de CMI foram idênticos aos obtidos com a versão não amidada de PaDBS1R1 (Tabela 7). Adicionalmente, foi testada a atividade frente as bactérias Gram-negativa e Gram-positiva resistentes aos antibióticos. Foi observada uma potente atividade de PaDBS1R1-amida contra $K$. pneumoniae resistente a carbapenemos $(\mathrm{KPC})(\mathrm{CMI}=6,25$ $\mu \mathrm{M}$ ) assim como uma atividade menos forte em termos de CMI, contra S. aureus resistente a meticilina $(\mathrm{MRSA})(\mathrm{CMI}=12,5 \mu \mathrm{M})($ Tabela 7$)$. 
Tabela 7. Espectro de atividades antimicrobiana e citotóxica de PaDBS1R1 e PaDBS1R1-amida.

\begin{tabular}{lcc}
\hline Microrganismo & \multicolumn{2}{c}{ Concentração Mínima Inibitória } \\
$(\boldsymbol{\mu M})$
\end{tabular}

\subsection{Atividade hemolítica e citotóxica sobre linhagens celulares humanas}

$\mathrm{O}$ resultado do ensaio hemolítico expresso pelo valor $\mathrm{LC}_{50}$, determinou que PaDBS1R1 não apresenta atividade hemolítica frente a eritrócitos humanos $\left(\mathrm{LC}_{50}=50\right.$ $\mu \mathrm{M}$ ), com valor $\mathrm{LC}_{50}$ superior aos valores de CMIs da maioria das bactérias Gramnegativas e positivas testadas, conforme indicado na Tabela 7.

O ensaio colorimétrico MTT foi utilizado para avaliar a toxicidade do peptídeo PaDBS1R1 frente as linhagens de células humanas: macrófagos derivados de monócitos THP-1 e células embrionárias do rim HEK-293. Os resultados, expressos em valores $\mathrm{LC}_{50}$, indicaram que PaDBS1R1 não apresentou efeito citotóxico frente as células HEK$293\left(\mathrm{LC}_{50}=143,2 \pm 30,9 \mu \mathrm{M}\right)$, sendo o valor de $\mathrm{LC}_{50}$ superior aos valores CMIs determinados para as bactérias testadas $(1,5-12,5 \mu \mathrm{M})$ (Tabela 7). No caso dos 
macrófagos THP-1, o peptídeo PaDBS1R1 mostrou atividade citotóxica, com um valor baixo de $\operatorname{LC}_{50}(7,3 \pm 3,0 \mu \mathrm{M})$.

\subsection{Permeabilização e despolarização da membrana bacteriana}

A capacidade de PaDBS1R1 de produzir alterações na membrana plasmática de bactérias, foi avaliada nas cepas de referência E. coli ATCC 25922 e S. aureus ATCC 25923, na presença do peptídeo na concentração correspondente à 2 vezes o valor da CMI $(6,25 \mu \mathrm{M})$. A permeabilidade e a despolarização da membrana citoplasmática bacteriana foram monitoradas com SYTOX Green (SG) e DiSC3(5), respectivamente, utilizando o peptídeo melitina $(5 \mu \mathrm{M})$ como controle positivo. A Figura 17 revela que PaDBS1R1 possui a habilidade de permear as membranas de E. coli (Figura 17A) e S. aureus (Figura 17B), como indicado pelo aumento da intensidade da fluorescência da sonda SG, comparado ao controle negativo (PBS). No caso de E. coli, observou-se um padrão de permeabilização induzida por PaDBS1R1, similar ao obtido para a melitina. Para $S$. aureus, o sinal de SG foi maior com PaDBS1R1 que com o peptídeo melitina. Também, observa-se na Figura 17 que, na presença de PaDBS1R1, uma despolarização completa de ambas as membranas de E. coli (Figura 17C) e S. aureus (Figura 17D) foi rapidamente atingida $(<5 \mathrm{~min})$. 
A.

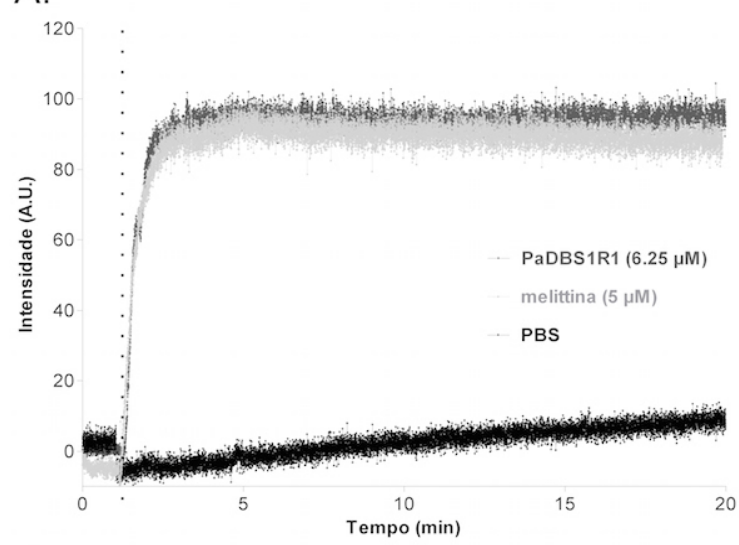

C.

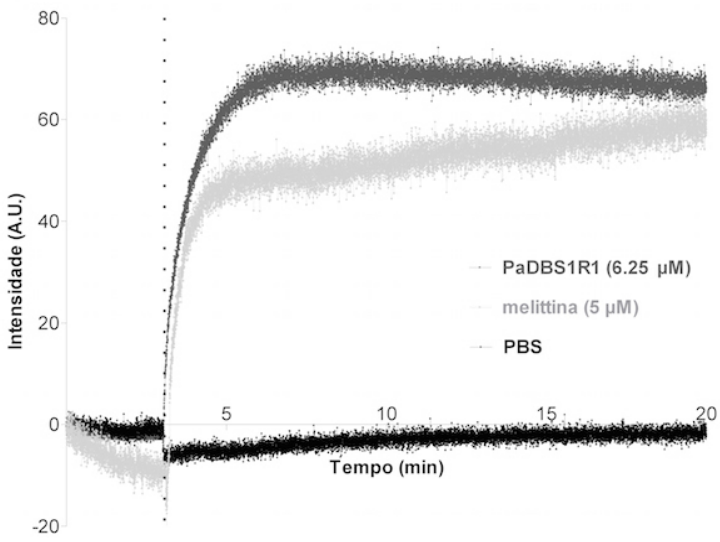

B.

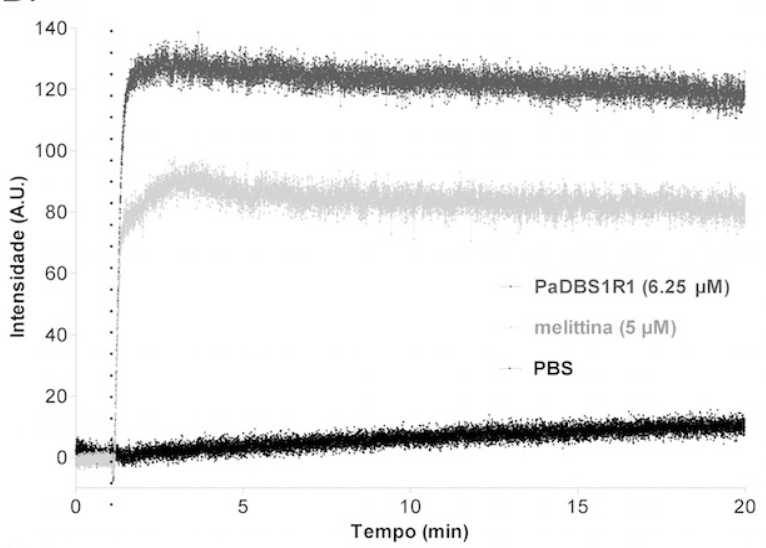

D.

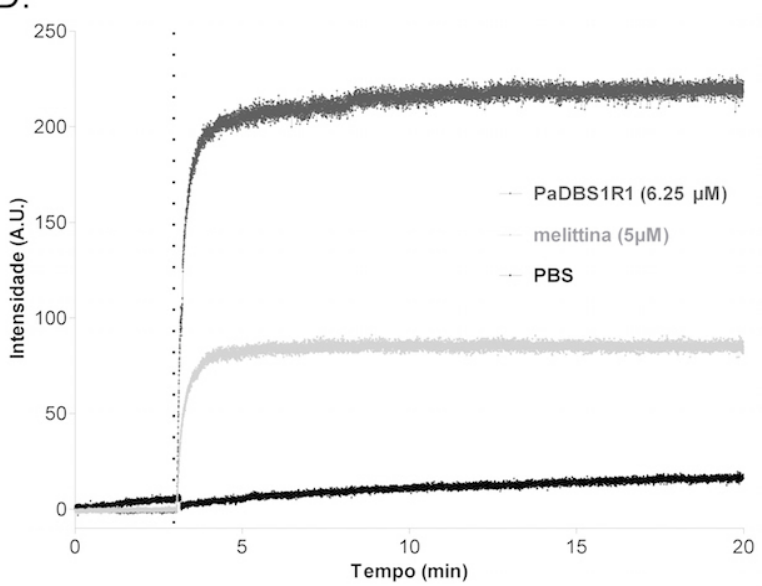

Figura 17. Efeito de PaDBS1R1 sobre a integridade da membrana plasmática de E. coli ATCC 25922 e S. aureus ATCC 25923. Cinética da emissão de fluorescência da sonda (A, B) SYTOX Green e (C, D) DiSC3(5) em função do tempo, após adição de peptídeo (linha pontilhada vertical). Permeabilização da membrana citoplasmática de E. coli (A) e S. aureus (B) induzida por PaDBS1R1 na concentração correspondente à 2 vezes o valor da CMI $(6,25 \mu \mathrm{M})$. Despolarização induzida por PaDBS1R1 (mesma concentração) sobre a membrana citoplasmática de $E$. coli (C) e $S$. aureus (D). O controle negativo corresponde as células bacterianas incubadas em PBS na ausência do peptídeo, enquanto o controle positivo corresponde à incubação com $5 \mu \mathrm{M}$ de melitina. 


\subsection{Cinética da atividade antibacteriana in vitro}

A atividade bactericida de PaDBS1R1 contra $E$. coli e $S$. aureus foi investigada na concentração idêntica àquela utilizada nos ensaios de permeabilização e despolarização $(6,25$ $\mu \mathrm{M})$. Os resultados representados pelas curvas de morte na Figura 18 mostram que o PaDBS1R1 causou uma rápida morte de E. coli em menos de 5 min, e uma morte mais tardia de $S$. aureus, após 30 min. É preciso aclarar que o tempo mínimo da primeira medição por questões experimentais corresponde a $5 \mathrm{~min}$.

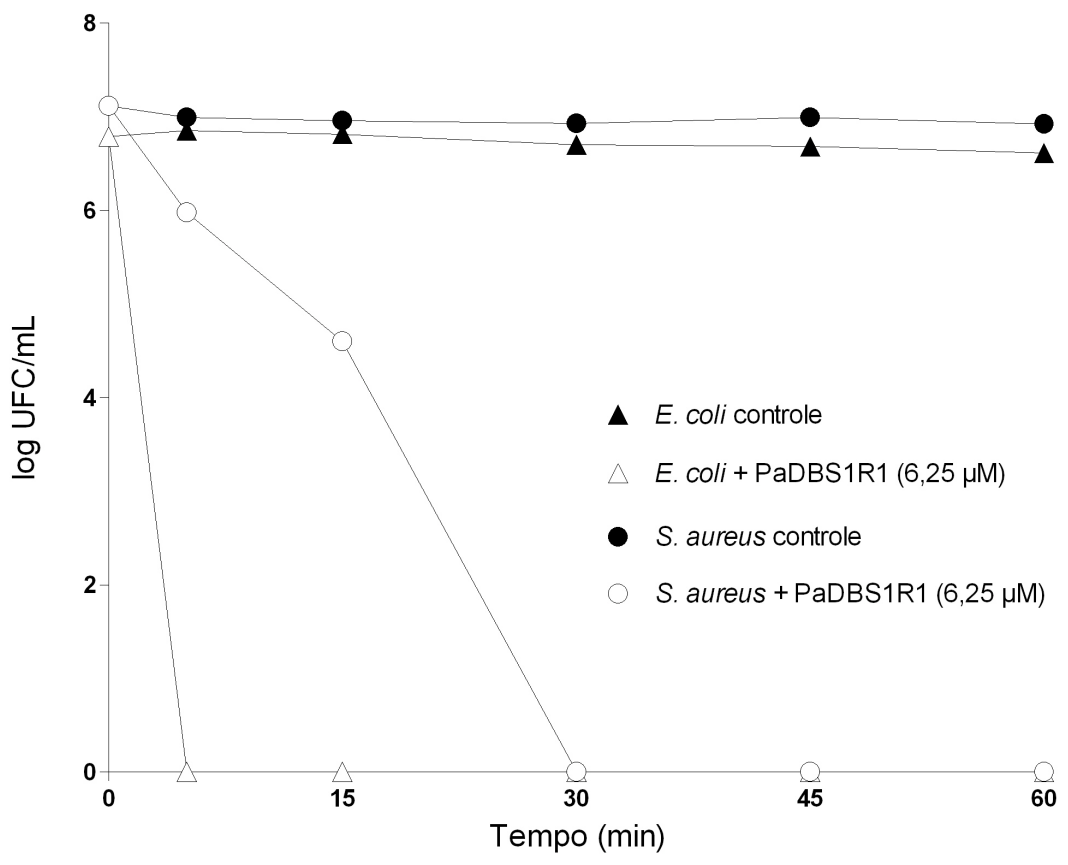

Figura 18. Cinética da morte celular de E. coli ATCC 25922 (triângulos brancos) e S. aureus ATCC 25923 (círculos brancos) após incubação com 6,25 $\mu \mathrm{M}$ de PaDBS1R1 (dobro da CMI). O controle foi realizado em ausência de peptídeo. Os resultados são expressos como a média dos valores representativos de um experimento realizado em triplicata.

\subsection{Visualização da atividade antimicrobiana por MEV-FEG}

As possíveis alterações na integridade das membranas microbianas causadas por PaDBS1R1 foram investigadas por meio de MEV-FEG nas bactérias sensíveis $P$. aeruginosa ATCC 27853 e L. ivanovii Li 4pVS2. Conforme pode ser visto na Figura 19, todas as células 
bacterianas sofreram alterações na membrana após interação com PaDBS1R1. Observou-se uma deformação na membrana das células de $P$. aeruginosa quando foram incubadas com 3,125 $\mu \mathrm{M}$ (duas vezes acima da CMI) e $50 \mu \mathrm{M}$ de PaDBS1R1 (Figura 19B-C), quando comparado com as células controle (Figura 19A). No caso de L. ivanovii, a potente atividade de PaDBS1R1, confirmou-se pela presença de numerosas células lisadas e restos celulares quando foram incubadas com 3,125 $\mu \mathrm{M}$ (CMI) (Figura 19F), e 6,25 $\mu \mathrm{M}$ (duas vezes acima da CMI) (Figura 19F) em comparação com as células controle (Figura 19D).
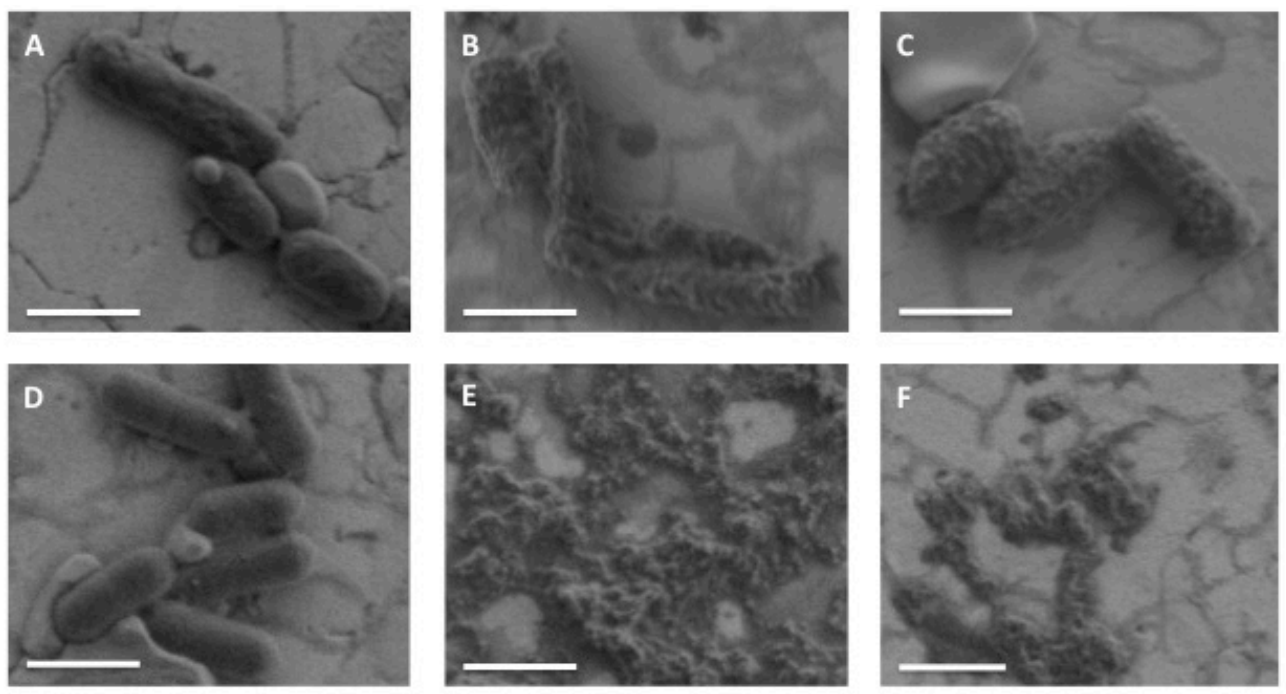

Figura 19. Imagens obtidas por MEV-FEG do efeito de PaDBS1R1 sobre as células de (A-C) $P$. aeruginosa ATCC 27853 e (D-F) L. ivanovii Li 4pVS2. (A, D) Células controle, na ausência de PaDBS1R1. (B, C) P. aeruginosa, incubadas com 3,125 $\mu \mathrm{M}$ PaDBS1R1 (dobro da CMI) e $50 \mu \mathrm{M}$, respectivamente. (E, F) L. ivanovii incubadas com 3,125 $\mu \mathrm{M}$ PaDBS1R1 (CMI) e 6,25 $\mu \mathrm{M}$ (dobro da $\mathrm{CMI})$, respectivamente. Barras $=1 \mu \mathrm{m}$.

\subsection{Análise de estrutura tridimensional por espectroscopia de DC e RMN}

Estudos estruturais por dicroísmo circular (DC) foram realizados para determinar as preferências conformacionais adotadas pelo peptídeo PaDBS1R1 em diferentes meios e pH, com o intuito de obter detalhes sobre o modo de interação com a membrana. Os resultados destes estudos, apresentados pela Figura 20A, permitem observar que PaDBS1R1 exibiu 
estrutura predominantemente randômica em água em pH 4, 7 e 10. A estrutura randômica está indicada pelas elipticidades positivas próximo de $219 \mathrm{~nm}$, e pelas elipticidades negativas próximo de $200 \mathrm{~nm}$.

Por outro lado, foram observadas mudanças significativas no espectro DC de PaDBS1R1 em presença de $20 \mathrm{mM}$ SDS (micelas carregadas negativamente), em diferentes $\mathrm{pH}$, adquirindo uma maior estruturação em hélice, equivalente a 100\%, como pode ser observado pela presença de uma região positiva próximo de $192 \mathrm{~nm}$, seguida de dois mínimos com valores negativos em $207 \mathrm{~nm}$ e em $222 \mathrm{~nm}$. Quando comparado ao espectro DC de PaDBS1R1 em presença de 20 mM DPC (micelas de dodecilfosfocolina, surfactante zwitteriônico), o peptídeo apresentou menor estruturação que aquela observada em presença de SDS.

Os experimentos de DC foram de extrema importância para podermos delimitar as condições a serem utilizadas nos experimentos de ressonância magnética nuclear (RMN), bem como para melhor entendimento da influência dos diferentes meios na estrutura secundária dos peptídeos em estudo. Desta forma, a estrutura tridimensional de PaDBS1R1 foi investigada por espectroscopia de RMN em pH neutro e micelas de SDS. O procedimento de assinalamento das ressonâncias dos prótons foi realizado utilizando o espectro de ${ }^{1} \mathrm{H}-{ }^{1} \mathrm{H}$ TOCSY (Figura $2 \mathrm{C}$ em Apêndice I). As restrições conformacionais foram extraídas do mapa de contornos de NOESY (Figura 2B em Apêndice I), as intensidades dos picos foram convertidos em um conjunto de limites inferior e superior para as distâncias entre os pares de átomos, chamadas de restrições de distâncias. Segundo a metodologia desenvolvida por Wüthrich, o sistema de spins dos resíduos de aminoácidos bem como suas conectividades, foram determinados através da análise simultânea TOCSY e NOESY (Wuthrich, 1983).

O diagrama de conectividades $\mathrm{NOE}$ (Figura 2C, Apêndice I), que indica a região provável de estruturação do peptídeo, não apresentou correlações i, i+3 referente as correlações $19 \mathrm{HN}-16 \mathrm{H}_{\alpha}, 17 \mathrm{HN}-14 \mathrm{H}_{\alpha}, 16 \mathrm{NH}-13 \mathrm{H}_{\alpha}$ e $15 \mathrm{HN}-12 \mathrm{H}_{\alpha}$, devido aos sinais de $\mathrm{H}_{\alpha}$ se localizarem na 
mesma linha de ressonância da sua correlação (i+3) HN.

A predição da estrutura secundária de PaDBS1R1 realizou-se utilizando o método proposto por Wishart para peptídeos (Wishart et al., 1992), e a sua análise foi gerada na interface do programa nmrVIEW. O índice de deslocamento químico (chemical shift index, CSI) dos núcleos de $\mathrm{H}_{\alpha}, \mathrm{C}_{\alpha} \mathrm{e} \mathrm{N}$, foram utilizados como um indicativo de estrutura secundária e indicaram a presença de uma estrutura secundária em $\alpha$-hélice entre os resíduos de Lys- 2 e Lys19 (Figura 3A em Apêndice I).

A partir dos experimentos de HSQC de ${ }^{13} \mathrm{C}$ e HMQC de ${ }^{15} \mathrm{~N}$, foram preditos os ângulos de torção PHI $(\phi)$ e PSY $(\psi)$, utilizando o programa TALOS+ (Shen et al., 2009). A predição foi classificada como apresentado uma boa predição para os resíduos de aminoácidos (dados não mostrados), exceto para o resíduo Lys-2 classificado como ambíguo, além de indicar uma estruturação em $\alpha$-hélice do resíduo Leu-4 ao Phe-18.

Os elementos de estrutura secundária preditos pelo CSI, concordaram com o previsto pelo programa TALOS+, sendo assim prosseguiu-se os estudo, pela análise das restrições que seriam utilizadas nos cálculos, utilizando o programa QUEEN (Quantitative Evaluation of Experimental NMR Restraints), esse programa faz uma avaliação quantitativa das restrições experimentais (Nabuurs et al., 2003). Assim, o programa QUEEN permitiu verificar e corrigir possíveis erros de atribuições pelas análises das restrições que apresentavam alta unicidade. As restrições utilizadas nos cálculos das estruturas apresentam baixa unicidade $\left(\mathrm{I}_{\text {uni }}\right)$ (Figura 3C em Apêndice I), confirmando a confiabilidade das restrições utilizadas, pela ausência de restrições não suportadas pelo conjunto. As informações de média distância ( $\mathrm{I}_{\text {med }}$ ) (Figura 3D em Apêndice I), ou seja, as restrição que contêm a maior parte da informação estrutural, indicaram uma maior importância para as restrições de média distância. Esta informação confirma que a restrição intra-residual, como esperado, contém apenas poucas informações estruturais, embora 
componham uma parte importante do conjunto de dados úteis para confirmar as atribuições e indicar a integralidade dos conjuntos de dados.

Após a análise da lista de restrições, foram realizados os cálculos estruturais. Foram utilizadas 278 restrições de distâncias, totalizando uma média de 16,4 restrições por resíduo. Um total de 200 estruturas foram calculadas, sendo selecionadas as 20 estruturas de menor energia para o processo de refinamento em água (Linge et al., 2003). As 10 estruturas de menor energia das 20 foram selecionadas para representar a família de estruturas. A precisão das estruturas resolvidas por RMN, foi expressa em função de RMSD, como uma medida da qualidade da estrutura (Nabuurs et al., 2004). Através do programa MOLMOL (Koradi et al., 1996), as 10 estruturas de menor energia foram sobrepostas e obtidos os valores de RMSD (Figura 3B em Apêndice I). Os valores de RMSD, evidenciaram que as estruturas exibem uma boa geometria indicando uma boa flexibilidade conformacional, refletindo a dinâmica interna da molécula e as incertezas que derivam da conversão experimental dos dados e processos computacionais (Spronk et al., 2003). A existência de conformações convergentes mostra a consistência e compatibilidade das restrições utilizadas no cálculos estruturais.

As estruturas apresentadas na Figura 20B, foram avaliadas quanto a sua qualidade estereoquímica através do site ramachandran plot (http://mordred.bioc.cam.ac.uk/ rapper/rampage.php) (Ramachandran et al., 1963; Ramakrishnan e Ramachandran, 1965). A combinação dos ângulos diedros $\phi$ e $\psi$, baseada em considerações estéricas, indicou boa qualidade estrutural pois $95,5 \%$ dos ângulos $\phi$ e $\psi$, se localizaram nas regiões favorecidas características de $\alpha$-hélice. A estrutura obtida através de dados experimentais por RMN confirma os resultados obtidos através dos experimentos de DC e indicam uma estrutura secundária de PaDBS1R1 em $\alpha$-hélice anfipática, com segmentos helicoidais bem definidos do resíduo Leu-4 ao Phe-18 e a face hidrofóbica como a face provável de interação peptídeo-micela SDS (Figura 20B). 

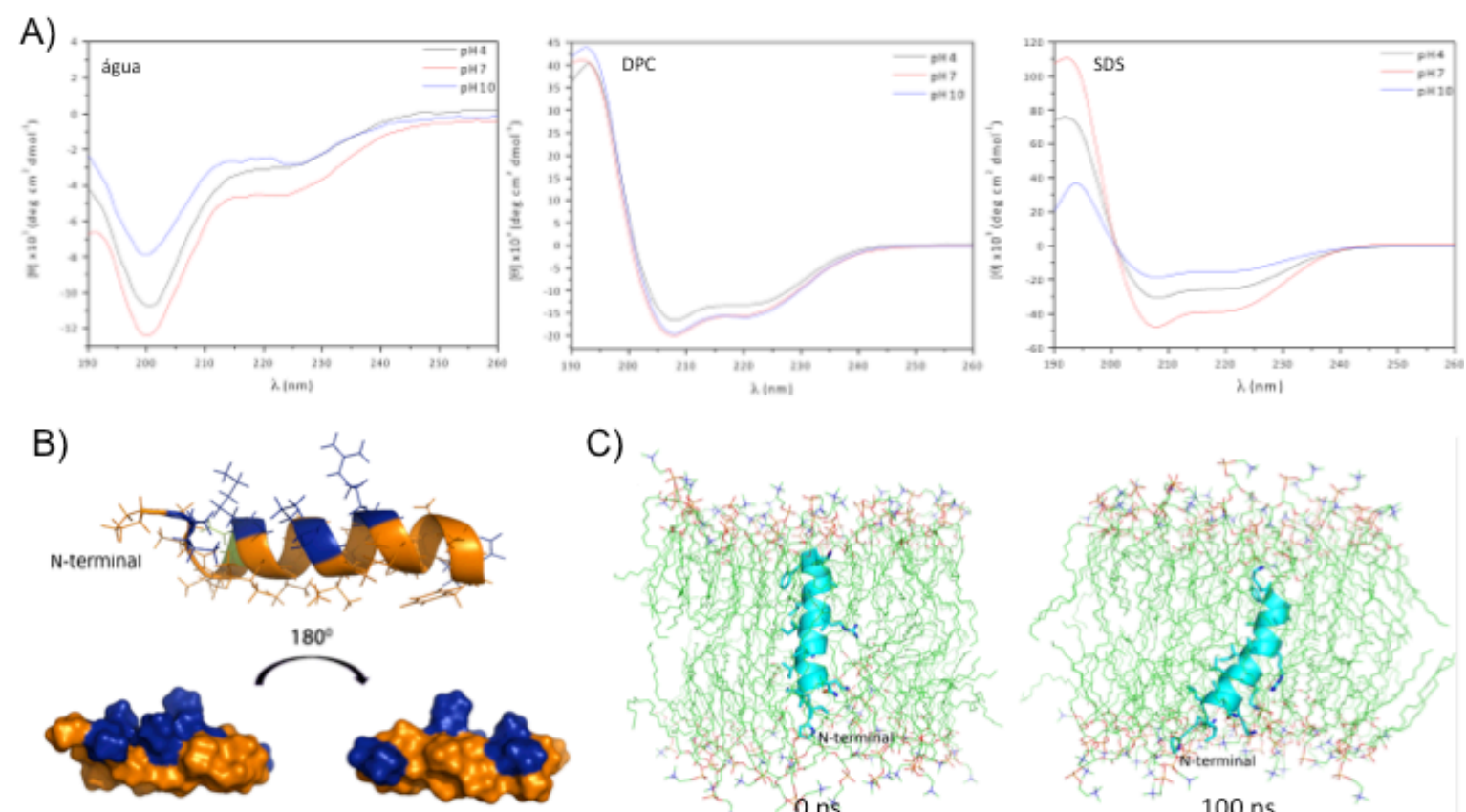

C)
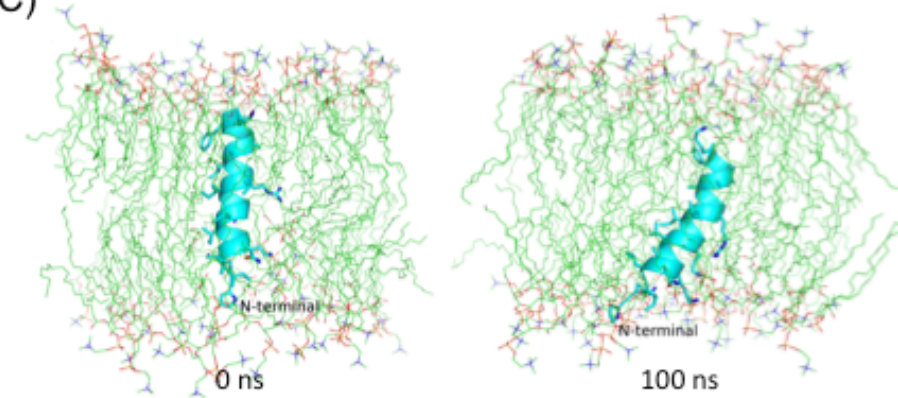

Figura 20. Análise da estrutura tridimensional de PaDBS1R1. (A) Espectros de dicroísmo circular (DC) do peptídeo PaDBS1R1 $(50 \mu \mathrm{M})$ em água; em $20 \mathrm{mM}$ de DPC e $20 \mathrm{mM}$ de SDS, a $25^{\circ} \mathrm{C}$ e pH 4, 7 e 10 , sendo $[\theta]_{\text {molar }}$ em função do comprimento de onda $\lambda(\mathrm{nm})$. (B) Estrutura de PaDBS1R1 resolvida por RMN, confirmando a estrutura $\alpha$-hélice observada por DC. Os resíduos de aminoácidos catiônicos estão representados em azul, os aniônicos em verde, e os hidrofóbicos em amarelo. (C) Análise estrutural in silico da interação peptídeo-membrana para PaDBS1R1 em membrana DOPC, posição inicial a $0 \mathrm{~ns}$ (esquerda) e posição final após 100 ns de simulação (direita).

\subsection{Simulação in silico da interação com membrana DOPC}

Com base na informação de espectroscopia em ambientes hidrofóbicos, o peptídeo PaDBS1R1 aparentemente adota uma conformação de $\alpha$-hélice. A fim de verificar o comportamento de PaDBS1R1 em um ambiente de membrana, foi realizado um experimento de simulação por dinâmica molecular in silico em ambiente DOPC. A $37^{\circ} \mathrm{C}$ a bicamada DOPC encontra-se na fase líquida e com estrutura fluida, caráter biologicamente relevante (Huang et al., 1994). Em tal ambiente, o PaDBS1R1 exibiu uma conformação de $\alpha$-hélice (Figura 20C) com valor de RMSD por baixo de $2 \AA$ durante toda a simulação (dados não mostrados). No entanto, observou-se uma variação da posição no interior da membrana, na qual, a posição inicial (0 ns) encontrou-se alinhada com o eixo $\mathrm{Z}$, mas apresentou-se diagonal respeito do eixo 
Z após 100 ns de simulação. Tal variação parece estar relacionada com a porção N-terminal $\left({ }^{1}\right.$ PKILNKILGK $\left.{ }^{10}\right)$ altamente carregada, e a porção altamente hidrofóbica C-terminal $\left({ }^{11}\right.$ ILRLAAAFK $\left.^{19}\right)$. Consequentemente, a porção N-terminal estaria interagindo com os grupos fosfatos polares, enquanto a porção C-terminal interage com as caudas lipídicas hidrofóbicas (Figura 20C). 


\section{Parte 4: Análise comparativa dos peptídeos desenhados}

\subsection{Atividades antimicrobiana e citotóxica}

Os dados apresentados na Tabela 8 permitem realizar uma análise comparativa das atividade antimicrobiana e citotóxicas dos 5 peptídeos em estudo. De forma geral, a ação antimicrobiana dos peptídeos revelou-se mais potente frente às bactérias Gram-negativas com valores de CMI no intervalo 1,5 - 12,5 $\mu \mathrm{M}$. No caso das bactérias Gram-positivas, os valores de CMI revelaram uma ação antibacteriana moderada para os peptídeos $\left[\mathrm{I}^{5}, \mathrm{R}^{8}\right] \mathrm{MP}$ e EcDBS1R6 $(3,125$ - $50 \mu \mathrm{M})$ e potente para PaDBS1R1 $(3,125 \mu \mathrm{M})$, com a exceção da espécie E. faecalis. Os peptídeos $\left[\mathrm{I}^{5}, \mathrm{R}^{8}\right] \mathrm{MP}$ e PaDBS1R1 apresentaram atividade antifúngica. A avaliação das possíveis mudanças nos valores de CMI após amidação do C-terminal dos peptídeos, mostrou um aumento de atividade para o $\left[\mathrm{I}^{5}, \mathrm{R}^{8}\right] \mathrm{MP}$, e valores idênticos para o PaDBS1R1. A comparação dos valores de citotoxicidade dos peptídeos, indica ausência de atividade hemolítica para os peptídeos $\left[\mathrm{I}^{5}, \mathrm{R}^{8}\right] \mathrm{MP}$ e EcDBS1R1, com valores de $\mathrm{LC}_{50}>200$ $\mu \mathrm{M}$, e a ausência de atividade citotóxica para todos os peptídeos frente às células HEK-293, com valores de $\mathrm{LC}_{50}$ no intervalo $111-200 \mu \mathrm{M}$.

Tabela 8. Espectro de atividades antimicrobiana e citotóxica dos 5 peptídeos racionalmente desenhados.

\begin{tabular}{|c|c|c|c|c|c|}
\hline \multirow[t]{2}{*}{ Microrganismo } & \multicolumn{5}{|c|}{ Concentração Mínima Inibitória $(\mu \mathrm{M})$} \\
\hline & {$\left[{ }^{5}, \mathrm{R}^{8}\right] \mathrm{MP}$} & $\begin{array}{l}{\left[\mathrm{I}^{5}, \mathrm{R}^{8}\right] \mathrm{MP}} \\
\text { amida }\end{array}$ & EcDBS1R6 & PaDBS1R1 & $\begin{array}{l}\text { PaDBS1R1 } \\
\text { amida }\end{array}$ \\
\hline Escherichia coli ATCC 25922 & 12,5 & NTa & 3,125 & $3,125 / 1,5$ & 1,5 \\
\hline Pseudomonas aeruginosa ATCC 27853 & 6,25 & NT & 6,25 & 1,5 & 1,5 \\
\hline Klebsiella pneumoniae ATCC 13883 & 6,25 & 3,125 & 3,125 & 1,5 & NT \\
\hline Acinetobacter baumannii ATCC 19606 & 3,125 & NT & 3,125 & 1,5 & NT \\
\hline $\begin{array}{l}\text { K. pneumoniae resistente a } \\
\text { carbapenêmicos }(3259271)\end{array}$ & NT & 3,125 & NT & NT & 6,25 \\
\hline Staphylococcus aureus ATCC 25923 & 25 & 6,25 & 3,125 & 3,125 & 3,125 \\
\hline Streptococcus pyogenes ATCC 19615 & 6,25 & NT & 25 & 3,125 & 3,125 \\
\hline Listeria ivanovii Li 4pVS2 & 50 & NT & 12,5 & 3,125 & 3,125 \\
\hline Enterococcus faecalis ATCC 29212 & $>100$ & NT & $>100$ & 50 & 50 \\
\hline $\begin{array}{l}\text { S. aureus resistente a meticilina } \\
\text { (7133623) }\end{array}$ & NT & 3,125 & NT & NT & NT \\
\hline Candida albicans ATCC 90028 & 12,5 & NT & 100 & $\geq 50$ & NT \\
\hline C. parapsilosis ATCC 22019 & 25 & NT & 100 & 25 & NT \\
\hline Células humanas & \multicolumn{5}{|c|}{ Concentração Lítica $50(\boldsymbol{\mu M})$} \\
\hline
\end{tabular}




\begin{tabular}{l|c|c|c|c|cc}
\hline Macrófagos THP-1 & $24,5 \pm 12,9$ & NT & $5,1 \pm 1,1$ & $7,3 \pm 3,0$ & NT \\
HEK-293 & $>200$ & NT & $111,0 \pm 27,2$ & $143,2 \pm 30,9$ & NT \\
Eritrócitos & $>200$ & NT & $>200$ & 50 & NT \\
\hline
\end{tabular}

${ }^{\text {a}}$ : Não testado. Concentração mínima inibitória (CMI) e concentração lítica 50 (LC 50 , expressas como valores médios de 3 experimentos independentes realizados em triplicata.

\section{2 Índice terapêutico (TI)}

Com o intuito de avaliar o potencial terapêutico dos 3 peptídeos racionalmente desenhados, foi calculado o índice terapêutico (IT). O IT considera-se um parâmetro importante no estudo do equilíbrio entre os efeitos tóxicos e desejados para um fármaco. Foi utilizada a equação (1) adaptada do estudo de Chen e colaboradores no ano 2005 (Chen et al., 2005).

$$
T I=\frac{\sqrt[n]{\prod_{i=1}^{n} L C 50_{i}}}{\sqrt[m]{\prod_{j=1}^{m} M I C_{j}}}(1)
$$

Sendo $n$ o número de valores $\mathrm{LC}_{50}$ e $m$ o número de valores CMI. Para valores superiores à concentração máxima testada, assumiu-se 2 vezes o valor máximo testado (por exemplo, se o valor resultou $>100$, considerou-se como 200) (Chen et al., 2005).

Por meio da equação (1), os valores calculados para $\left[\mathrm{I}^{5}, \mathrm{R}^{8}\right]$ MP, EcDBS1R6 e PaDBS1R1 foram 10.29, 12.11 e 11.14, respectivamente. Consequentemente, pode-se sugerir que os 3 peptídeos desenhados apresentaram baixa toxicidade, sendo que doses superiores à 10 seriam necessárias para causar efeitos tóxicos nas células de mamífero testadas in vitro. 


\section{DISCUSSÃO}

Nos dias de hoje, os peptídeos têm sido considerados como potentes candidatos para a geração de uma nova classe de drogas, oferecendo uma alternativa interessante para abordar o crescente problema da resistência aos antibióticos. Novos AMPs caracterizados recentemente, inspiram modelos moleculares para o desenvolvimento de agentes terapêuticos inovadores e, à medida que serão descobertos, continuarão a possibilitar estratégias antimicrobianas, porque foram baseados em estratégias de defesa que provaram ser eficazes ao longo dos milênios (Zasloff, 2002). Embora as bactérias tenham mecanismos de resistência contra esses peptídeos, a multifuncionalidade dos AMPs poderia fugir à resistência bacteriana (Franco, 2011).

Apesar do grande potencial terapêutico, a aplicação dos AMPs de origem natural na clínica, tem sido um sucesso limitado (Zhang e Falla, 2006). Existem certos obstáculos para o uso dos AMPs como agentes antiinfecciosos. Dentre eles, destaca-se o seu potencial de toxicidade. Todos os ensaios clínicos com peptídeos até à data, têm usados aplicações tópicas para tratar infecções de superfície, em vez da administração com efeito sistêmico (de tipo parenteral e/ou oral) que corresponde ao mercado mais lucrativo (Kosikowska e Lesner, 2016). Além disso, durante a última década, apenas duas novas classes de antibióticos chegaram ao mercado, a oxazolidinona (linezolida por Pfizer) e um lipopeptídeo cíclico (daptomicina por Cubist), ativas contra bactérias Gram-positivas tais como MRSA, porém não tem se registrado novas classes em ensaios clínicos de fase II ou III (Coates et al., 2011). Frente aos obstáculos da aplicação terapêutica dos AMPs, o desenho racional de sequências peptídicas proporciona uma alternativa eficiente para o desenvolvimento de novos fármacos. Pesquisas recentes do nosso grupo mostram que esta abordagem pode ser utilizada na predição, geração e/ou otimização de AMPs (Porto, 2010; Porto et al., 2012; Mandal et al., 2014).

Com a perspectiva de utilizar uma abordagem racional para a geração de novas sequências peptídicas antimicrobianas, os métodos de desenho in silico ofereceram a base para 
o presente estudo. A partir de métodos baseados em sequência modelo, construiu-se uma grande variedade de sequências com potencial aplicação terapêutica. A síntese realizou-se por meio da estratégia spot array na qual os múltiplos peptídeos são fixos em suporte sólido, neste caso uma superfície de celulose. Posteriormente, a membrana de celulose foi usada para determinação da atividade antibacteriana dos peptídeos frente a bactéria bioluminiscente $P$. aeruginosa H1001. Esta cepa mutante foi escolhida porque ela expressa luminescência de uma forma abundante e constitutiva, e porque Pseudomonas sp. representa um dos principais agentes patogénicos resistentes aos antibióticos, sendo assim um alvo importante para o desenvolvimento de antibióticos (Hilpert e Hancock, 2007). Esta técnica possibilitou a análise de uma grande quantidade de sequencias para a escolha de peptídeos com potencial antimicrobiano de forma rápida e eficiente. Os peptídeos selecionados $\left[\mathrm{I}^{5}, \mathrm{R}^{8}\right] \mathrm{MP}$, EcDBS1R6 e PaDBS1R1, constituíram o objeto de estudo do presente trabalho. Utilizando-se a técnica Fmoc síntese, os 5 peptídeos foram sintetizados, subsequentemente purificados e cada um analisado por espectrometria de massas, análise que permitiu verificar a sua identidade e pureza.

Os peptídeos desenhados foram submetidos a diversos ensaios para determinar seu potencial terapêutico e investigar seu mecanismo de ação antimicrobiano. Iniciou-se o estudo avaliando o efeito bactericida contra variadas linhagens Gram-positivas e -negativas. Conforme ilustrado na Tabela 8, o espectro de ação dos peptídeos varia consideravelmente. De forma generalizada, todos mostraram maior atividade frente ás bactérias Gram-negativas $(\mathrm{CMI}=1,5-$ $12,5 \mu \mathrm{M})$ em comparação com as Gram-positivas $(\mathrm{CMI}=3,125-50 \mu \mathrm{M})$, com exceção da bactéria E. faecalis, para a qual unicamente o peptídeo PaDBS1R1, apresentou moderada atividade $(\mathrm{CMI}=50 \mu \mathrm{M})$. Cabe destacar que os melhores resultados foram obtidos para o peptídeo PaDBS1R1, de atividade bactericida de amplo espectro em concentrações micromolares $(\mathrm{CMI}=1,5-3,125 \mu \mathrm{M})$. Por outro lado, a maior concentração de peptídeo 
necessária para atingir o efeito letal sobre a espécie E. faecalis não é de surpreender, uma vez que esta bactéria tem demonstrado ser um agente patogênico resistente aos antibióticos, difícil de matar (Tong et al., 2014). Além disso, existe evidência de marcadas diferenças na composição lipídica da membrana de E. faecalis em comparação com as outras bactérias Grampositivas testadas neste trabalho (Mishra et al., 2012; Kumariya et al., 2015).

A partir do banco de dados APD (Antimicrobial Peptide Database), verifica-se um maior número de AMPs registrados com atividade exclusivamente para o combate a bactérias Grampositivas (16,2\% com atividade exclusiva contra Gram-positivas versus $8,1 \%$ contra Gramnegativas) (http://aps.unmc.edu/AP/main.php). Além disso, muitas IRAS são causadas por bactérias Gram-negativas resistentes aos antibióticos de uso convencional (Fox, 2013). Baseado nesses dados, os nossos resultados podem ser alentadores no sentido de enfrentar as deficiências de novos compostos peptídicos específicos para o tratamento de infecções originadas por bactérias Gram-negativas. Porém, cabe ressaltar que o método de screening utilizado para a seleção das sequências desenhadas a partir do algoritmo Joker, poderia estar relacionado com o resultado obtido. Dessa maneira, a tendência dos peptídeos à maior atividade frente as bactérias Gram-negativas é esperado, uma vez que eles demonstraram potente atividade contra $P$. aeruginosa bioluminiscente.

Adicionalmente, o efeito antifúngico dos peptídeos foi avaliado para duas cepas de Candida sp. Apenas $\left[\mathrm{I}^{5}, \mathrm{R}^{8}\right] \mathrm{MP}$ mostrou atividade contra $C$. albicans $(\mathrm{CMI}=12,5 \mu \mathrm{M})$ (Tabela 5). No caso de C. parapsilosis, obteve-se moderada ação antifúngica para $\left[\mathrm{I}^{5}, \mathrm{R}^{8}\right] \mathrm{MP}$ e PaDBS1R1 na concentração de $25 \mu \mathrm{M}$. Estes resultados podem ser explicados pelas diferenças químicas e estruturais da parede externa destas espécies de Candida, já relatadas. As cadeias laterais dos polímeros de manose, o principal componente da parede externa, variam entre as espécies C. albicans e C. parapsilosis desencadeando heterogeneidade nos componentes oligossacarídeos da parede interna (Shibata et al., 1995). Essas diferenças encontram-se 
relacionadas também à interação com células do sistema imune, participando na adesão às células epiteliais, no reconhecimento pelos receptores imunes e no desenvolvimento de patogenicidade (Shibata et al., 2012). Tendo isso em consideração, a falta de atividade antifúngica do peptídeo EcDBS1R6 sugere alguma deficiência na interação molecular com os componentes da parede fúngica que impediria ao peptídeo atingir a membrana plasmática do fungo.

Sabe-se que vários AMPs sofrem modificações pós traducionais que podem alterar a sua atividade biológica, particularmente aqueles peptídeos carboxamidados são muitas vezes mais eficazes em termos antimicrobianos, do que as formas não-amidadas (Ali et al., 2001; Katayama et al., 2002). Isto pode ser devido à neutralização da carga negativa do extremo Cterminal, aumentando assim a carga positiva líquida do peptídeo e/ou devido à proteção de degradação do peptídeo por parte de enzimas carboxipeptidases. Particularmente, estudos prévios revelaram uma intensificada ação antimicrobiana do peptídeo mastoparano e seus análogos na forma C-terminal amidada (Sforca et al., 2004; Da Silva et al., 2014). Assim, decidimos investigar possíveis mudanças na atividade antibacteriana dos peptídeos $\left[\mathrm{I}^{5}, \mathrm{R}^{8}\right] \mathrm{MP}$ e PaDBS1R1 carboxiamidados. Por um lado, em concordância com os dados da literatura, os resultados obtidos para $\left[\mathrm{I}^{5}, \mathrm{R}^{8}\right] \mathrm{MP}$ indicam que a amidação do $\mathrm{C}$-terminal conduziu a um aumento da atividade, com valores de CMI duas vezes menor contra K. pneumoniae, e três vezes menor contra S. aureus (ver Tabela 5). Pelo contrário, ao comparar os resultados de CMI para PaDBS1R1 nas formas amidada e não amidada, observam-se idênticos valores contra as bactérias testadas (E. coli, P. aeruginosa e S. aureus; ver Tabela 7), sugerindo que um aumento de carga e/ou proteção contra carboxipeptidases não seriam necessários para aumentar a potência de PaDBS1R1.

Afim de avaliar a atividade hemolítica dos peptídeos, bem como a toxicidade frente a células humanas, procedemos a determinar a concentração do peptídeo capaz de produzir a lise 
de $50 \%$ das células $\left(\mathrm{LC}_{50}\right)$. Desta maneira, os dados da capacidade hemolítica dos peptídeos revelaram a ausência de atividade hemolítica com valores superiores à $200 \mu \mathrm{M}$, para todos os peptídeos com a exceção de PaDBS1R1 que apresentou um valor menor de $50 \mu \mathrm{M}$, porém superior aos dados CMI $(1,5-3,125 \mu \mathrm{M})$ (Tabela 7). Além, os dados de $\mathrm{LC}_{50}$ indicaram que os 3 peptídeos desenhados não apresentam toxicidade sobre as células HEK-293 (células renais embrionárias humanas) $\left(\mathrm{LC}_{50} \cong 111-143 \mu \mathrm{M}\right.$ ). Enquanto ao efeito lítico frente as células THP-1 (macrófagos derivados de monócitos humanos), observou-se atividade citotóxica para os peptídeos PaDBS1R1 e EcDBS1R6, com valores de $\mathrm{LC}_{50}$ no intervalo $5-7 \mu \mathrm{M}$ sendo menores que os valores de CMI obtidos para os microrganismos testados. No caso do análogo $\left[\mathrm{I}^{5}, \mathrm{R}^{8}\right] \mathrm{MP}$, os nossos resultados indicaram atividade citotóxica frente as células THP-1, porém é de destacar que os dados contidos na Tabela 5 mostram a ausência de citotoxicidade para a maioria das bactérias testadas (bactérias Gram-negativas, bactérias resistentes aos antibióticos e S. pyogenes). Ainda, ao comparar com dados na literatura para o MP L, constatamos uma otimização referente à atividade antimicrobiana e citotóxica do análogo $\left[\mathrm{I}^{5}, \mathrm{R}^{8}\right] \mathrm{MP}$ (Leite et al., 2011; Lin et al., 2011; Konno et al., 2016).

Após a determinação da capacidade antimicrobiana dos peptídeos, o passo seguinte consistiu em estudar a permeabilização e despolarização de membranas bacterianas induzida por peptídeos assim como a cinética da sua atividade bactericida. Portanto, utilizou-se para esses estudos, uma concentração correspondente ao dobro da CMI a fim de garantir a correta observação do efeito dos peptídeos nas bactérias susceptíveis. Conforme os fins do estudo, as sondas SG e DiSC3(5) permitiram avaliar o efeito dos peptídeos sobre a integridade de membranas citoplasmáticas das bactérias Gram-negativa E. coli e Gram-positiva S. aureus, utilizando como referência a atividade do peptídeo melitina, de conhecida ação formadora de poros. Dessa maneira, a análise quantitativa da intensidade de fluorescência das sondas ao longo do tempo, permitiu determinar a habilidade de todos os peptídeos desenhados para 
permeabilizar e despolarizar ambas cepas bacterianas testadas. De forma detalhada, a cinética de permeabilização da membrana de $E$. coli induzida por PaDBS1R1 evidenciou-se mais rápida comparada aos outros peptídeos, no entanto a cinética de despolarização, mostrou-se similar para todos os peptídeos. No caso da membrana de $S$. aureus, todos os peptídeos induziram rapidamente a sua permeabilização e despolarização, porém a intensidade do efeito sobre a membrana (intensidade de fluorescência das sondas) revelou-se muito menor para o peptídeo EcDBS1R6. Contudo, nossos resultados nos levam a sugerir que todos os peptídeos apresentariam um mecanismo de ação bactericida dependente do comprometimento da integridade da membrana.

A velocidade de ação bactericida dos peptídeos, foi monitorada pela contagem de UFC após incubação com o peptídeo (na concentração $2 \mathrm{x}$ CMI). Em função dos resultados da cinética de morte, percebemos que o peptídeo EcDBS1R6 atua com a mesma velocidade frente a ambas bactérias Gram-negativa e Gram-positiva (15 min). A rápida ação bactericida de EcDBS1R6, comparada a baixa intensidade do efeito de permeabilização e despolarização da membrana bacteriana (Figura 13), nos leva a pensar que o mecanismo de ação poderia envolver a interferência em processos intracelulares, provocando eventualmente um bloqueio de divisão celular. No caso de $\left[\mathrm{I}^{5}, \mathrm{R}^{8}\right] \mathrm{MP}$ e PaDBS1R1, o ensaio de time-kill revelou que estes peptídeos atuam de forma mais rápida frente a bactéria $E$. coli que a bactéria $S$. aureus (diferença de 30 min entre as cepas). A rápida permeabilização e despolarização de $S$. aureus induzidas por $\left[\mathrm{I}^{5}\right.$, $\mathrm{R}^{8}$ ] MP (Figura 9) e PaDBS1R1 (Figura 17), sugere que o efeito sobre a integridade da membrana pode ser um fator importante no mecanismo de morte, no entanto, a capacidade de alterar a membrana bacteriana não representaria o passo letal. Desta forma, esses peptídeos poderiam estar envolvidos em eventos adicionais, tais como a translocação da membrana ou processos de sinalização intracelular. Além disso, o maior tempo necessário para matar a bactéria Gram-negativa em estudo, poderia estar indicando que a espessa camada de 
peptideoglicano e moléculas de ácido lipoteicoico, seriam responsáveis de retardar o passo dos peptídeos.

Com o intuito de obter maiores detalhes sobre o mecanismo bactericida, foram analisadas as possíveis alterações induzidas por peptídeos sobre a morfologia dos microrganismos susceptíveis, por meio de imagens de alta resolução obtidas pela técnica MEV-FEG. Com base nessas imagens podemos inferir que todos os peptídeos, em menor ou maior grau, provocaram danos na membrana dos microrganismos em estudo, ao compararmos com as imagens controle (células crescendo em ausência de peptídeo) (Figura 11, Figura 15 e Figura 19).

Afim de investigar em detalhe a interação dos peptídeos com as membranas biológicas, a predição da estrutura tridimensional dos peptídeos em estudo torna-se fundamental. Assim, a determinação estrutural teórica para o análogo MP e para o peptídeo EcDBS1R6 por meio da estratégia de simulação de dinâmica molecular e os estudos de DC e RMN para PaDBS1R1, permitiram determinar que todos os peptídeos, em ambiente de membrana, apresentam-se em conformação helicoidal anfipática. Essa preferência conformacional dos peptídeos constitui uma características fundamental para a análise da dinâmica de interação com as membranas fosfolipídicas. O estudo de interação com membranas DOPC permitiu observar que os peptídeos mantém a conformação durante a simulação, com poucas variações espaciais, permitindo uma interação da face hidrofóbica da hélice com a região de caudas hidrofóbicas da bicamada lipídica. Podemos inferir que tais interações seriam cruciais para a inserção e estabilização dos peptídeos no centro da membrana bacteriana.

Peptídeos com conformação em hélice estão entre os mais abundantes e amplamente distribuídos na natureza (Huang et al., 2010). Com base no demonstrado sucesso dos peptídeos em hélice para a defesa inata, numerosos estudos têm sido realizados para otimizar o seu potencial para aplicações clínicas. Através da abordagem de desenho de novo, Mai et al. (2015) demonstraram a importância de manter uma estrutura $\alpha$-hélice anfipática para uma atividade 
biológica desejável. Além disso, a capacidade de assumir estrutura anfipática mostrou ser um requisito funcional importante na interação e posterior translocação dos AMPs nas membranas bacterianas (Giangaspero et al., 2001; Mai et al., 2015). Consistente com esta hipótese, no caso de PaDBS1R1, os nossos dados indicaram que a conformação $\alpha$-hélice anfipática promove tanto a interação eletrostática quanto hidrofóbica com a membrana, onde a face positiva tem como alvo a superfície aniônica da membrana bacteriana (cabeças polares dos fosfolipídeos) e os resíduos hidrofóbicos interagem com o núcleo da membrana (cadeias hidrocarbonadas dos fosfolipídeos). Consequentemente, o peptídeo PaDBS1R1 insere-se na bicamada lipídica, induzindo perturbações e produzindo a permeabilização da membrana, que posteriormente conduz à lise celular. Considerando as informações aqui apresentadas, sobressai a possibilidade de utilização das novas sequências peptídicas $\left[\mathrm{I}^{5}, \mathrm{R}^{8}\right] \mathrm{MP}$, EcDBS1R6 e PaDBS1R6 como protótipos para o desenvolvimento de novos agentes antimicrobianos. 


\section{CONCLUSÕES}

No presente estudo, 3 sequências peptídicas obtidas a partir do desenho racional foram propostas como potenciais peptídeos antimicrobianos. Tais sequências, denominadas $\left[\mathrm{I}^{5}, \mathrm{R}^{8}\right]$ MP, EcDBS1R6 e PaDBS1R1, foram avaliadas quanto a seu potencial antimicrobiano frente a bactérias e fungos, assim como seu potencial tóxico frente a células humanas. Além, realizouse um estudo da sua estrutura tridimensional, mecanismo de ação e interação com membranas.

Os resultados obtidos permitem inferir que:

- A aplicação do nosso método de desenho racional possibilitou o desenvolvimento de 3 sequências peptídicas com alto potencial antimicrobiano in vitro contra bactérias Gram-positivas e -negativas, inclusive contra cepas resistentes à drogas e fungos do gênero Candida.

- O peptídeo PaDBS1R1 destacou-se por apresentar potente atividade antimicrobiana de amplo espectro em concentrações micromolares, incluindo bactérias resistentes, assim como uma rápida ação bactericida frente a bactéria $E$. $\operatorname{coli}(<5 \mathrm{~min})$.

- O cálculo do índice terapêutico sugeriu baixa toxicidade dos peptídeos desenhados frente às células humanas eritrócitos, macrófagos derivados de monócitos THP-1 e células renais embrionárias HEK-293.

- Otimizou-se a atividade antimicrobiana e citotóxica do peptídeo $\left[\mathrm{I}^{5}, \mathrm{R}^{8}\right] \mathrm{MP}$ respeito da sequência original, o peptídeo de origem natural mastoparano L.

- Todos os peptídeos em estudo demonstraram a habilidade de induzir a permeabilização e despolarização de membranas citoplasmáticas bacterianas Gram-negativas e -positivas. 
- A velocidade de ação bactericida dos peptídeos desenhados revelou-se rápida frente a $E$. coli e moderada frente a $S$. aureus.

- A visualização dos efeitos dos peptídeos desenhados sobre a morfologia dos microrganismos sensíveis sugeriu a capacidade de provocar danos na membrana citoplasmática.

- A avaliação estrutural determinou que os peptídeos desenhados apresentam conformação $\alpha$-hélice anfipática em ambientes lipídicos

- A avaliação funcional e estrutural dos peptídeos indicaria um mecanismo de ação de tipo membranolítico

- Os dados apresentados sugerem o uso da estratégia de desenho racional na identificação, seleção e otimização de peptídeos de aplicabilidade farmacológica e medicinal de grande interesse 


\section{PERSPECTIVAS}

- Continuar a avaliação citotóxica dos peptídeos desenhados frente a células humanas imunológicas, em diferentes tempos de exposição.

- Avaliar a biocompatibilidade dos peptídeos desenhados afim de definir o desempenho eficiente e não prejudicial ao hospedeiro, induzindo uma resposta vantajosa e apropriada durante o seu uso clínico.

- Realizar ensaios toxicológicos em modelos animais in vivo para avaliar o uso potencial na terapêutica.

- Realizar testes de sinergismo com antibióticos de uso convencional frente à bactérias resistentes.

- Aprofundar o estudo da interação peptídeo-membrana por meio do uso de vesículas miméticas de membranas biológicas, afim de obter informações detalhadas do mecanismo de ação e validar o modelo proposto. 


\section{REFERÊNCIAS}

ABBASSI, F. et al. Antibacterial and leishmanicidal activities of temporin-SHd, a 17residue long membrane-damaging peptide. Biochimie, v. 95, n. 2, p. 388-99, 2013.

AFACAN, N. J. et al. Therapeutic potential of host defense peptides in antibiotic-resistant infections. Curr Pharm Des, v. 18, n. 6, p. 807-19, 2012.

AHN, H. S. et al. Design and synthesis of novel antimicrobial peptides on the basis of alpha helical domain of Tenecin 1 , an insect defensin protein, and structure-activity relationship study. Peptides, v. 27, n. 4, p. 640-8, 2006.

ALEKSHUN, M. N.; LEVY, S. B. Molecular mechanisms of antibacterial multidrug resistance. Cell, v. 128, n. 6, p. 1037-50, 2007.

ALI, M. F. et al. Antimicrobial peptides isolated from skin secretions of the diploid frog, Xenopus tropicalis (Pipidae). Biochim. Biophys. Acta, v. 1550, n. 1, p. 81-9, 2001.

ALLEN, H. K. et al. Call of the wild: antibiotic resistance genes in natural environments. Nat. Rev. Microbiol., v. 8, n. 4, p. 251-9, 2010.

ANDRE, S. et al. Structure-activity relationship-based optimization of small temporin-SHf analogs with potent antibacterial activity. ACS Chem. Biol., v. 10, n. 10, p. 2257-66, 2015.

ANVISA. Manual de microbiologia clínica para o controle de infecção em serviços de saúde Ministério da Saúde, Agência Nacional de Vigilância Sanitária, 2004.

BERENDSEN, H. J. C. et al. Interaction models for water in relation to protein hydratation. Springer Netherlands, 1981.

BERGER, 0.; EDHOLM, O.; JAHNIG, F. Molecular dynamics simulations of a fluid bilayer of dipalmitoylphosphatidylcholine at full hydration, constant pressure, and constant temperature. Biophys. J., v. 72, n. 5, p. 2002-13, 1997.

BIGNAMI, G. S. A rapid and sensitive hemolysis neutralization assay for palytoxin. Toxicon, v. 31, n. 6, p. 817-20, 1993.

BLONDELLE, S. E.; LOHNER, K.; AGUILAR, M. Lipid-induced conformation and lipidbinding properties of cytolytic and antimicrobial peptides: determination and biological specificity. Biochim Biophys Acta, v. 1462, n. 1-2, p. 89-108, 1999.

BOWDISH, D. M.; DAVIDSON, D. J.; HANCOCK, R. E. A re-evaluation of the role of host defence peptides in mammalian immunity. Curr Protein Pept Sci, v. 6, n. 1, p. 35-51, 2005.

BROGDEN, K. A. Antimicrobial peptides: pore formers or metabolic inhibitors in bacteria? Nat. Rev. Microbiol., v. 3, n. 3, p. 238-50, 2005. 
BROWN, E. D.; WRIGHT, G. D. Antibacterial drug discovery in the resistance era. Nature, v. 529, n. 7586, p. 336-43, 2016.

BROWN, K. L.; HANCOCK, R. E. Cationic host defense (antimicrobial) peptides. Curr Opin Immunol, v. 18, n. 1, p. 24-30, 2006.

CHEN, Y. et al. Rational design of alpha-helical antimicrobial peptides with enhanced activities and specificity/therapeutic index. J. Biol. Chem., v. 280, n. 13, p. 12316-29, Apr 12005.

COATES, A. R.; HALLS, G.; HU, Y. Novel classes of antibiotics or more of the same? Br. J. Pharmacol., v. 163, n. 1, p. 184-94, 2011.

CORDWELL, S. J. Technologies for bacterial surface proteomics. Curr. Opin. Microbiol., v. 9, n. 3, p. 320-9, 2006.

DA COSTA, J. P. et al. Antimicrobial peptides: an alternative for innovative medicines? Appl. Microbiol. Biotechnol., v. 99, n. 5, p. 2023-40, Mar 2015.

DA SILVA, A. V. et al. The effects of the C-terminal amidation of mastoparans on their biological actions and interactions with membrane-mimetic systems. Biochim Biophys Acta, v. 1838, n. 10, p. 2357-68, 2014.

DARDEN, T.; YORK, D.; PEDERSEN, L. Particle mesh Ewald: an N·log(N) method for Ewald sums in large systems. J. Chem. Phys., v. 98, n. 12, p. 10089-10092, 1993.

DATHE, M. et al. General aspects of peptide selectivity towards lipid bilayers and cell membranes studied by variation of the structural parameters of amphipathic helical model peptides. Biochim. Biophys. Acta, v. 1558, n. 2, p. 171-86, 2002.

DATHE, M. et al. Optimization of the antimicrobial activity of magainin peptides by modification of charge. FEBS Lett., v. 501, n. 2-3, p. 146-50, 2001.

DATHE, M. et al. Peptide helicity and membrane surface charge modulate the balance of electrostatic and hydrophobic interactions with lipid bilayers and biological membranes. Biochemistry, v. 35, n. 38, p. 12612-22, 1996.

DATHE, M.; WIEPRECHT, T. Structural features of helical antimicrobial peptides: their potential to modulate activity on model membranes and biological cells. Biochim Biophys Acta, v. 1462, n. 1-2, p. 71-87, 1999.

DATHE, M. et al. Hydrophobicity, hydrophobic moment and angle subtended by charged residues modulate antibacterial and haemolytic activity of amphipathic helical peptides. FEBS Lett., v. 403, n. 2, p. 208-12, 1997.

DRIN, G.; ANTONNY, B. Amphipathic helices and membrane curvature. FEBS Lett, v. 584, n. 9, p. 1840-7, 2010. 
FINLAY, B. B.; HANCOCK, R. E. Can innate immunity be enhanced to treat microbial infections? Nat Rev Microbiol, v. 2, n. 6, p. 497-504, 2004.

FJELL, C. D. et al. Designing antimicrobial peptides: form follows function. Nat. Rev. Drug Discov., v. 11, n. 1, p. 37-51, 2012.

FJELL, C. D. et al. Optimization of antibacterial peptides by genetic algorithms and cheminformatics. Chem. Biol. Drug Des., v. 77, n. 1, p. 48-56, 2011.

FOSGERAU, K.; HOFFMANN, T. Peptide therapeutics: current status and future directions. Drug Discov Today, v. 20, n. 1, p. 122-8, Jan 2015.

FOX, J. L. Antimicrobial peptides stage a comeback. Nat Biotechnol, v. 31, n. 5, p. 379-82, May 2013.

FRANCO, O. L. Peptide promiscuity: an evolutionary concept for plant defense. FEBS Lett., v. 585, n. 7, p. 995-1000, 2011.

FRANK, R. The SPOT-synthesis technique. Synthetic peptide arrays on membrane supports--principles and applications. J Immunol Methods, v. 267, n. 1, p. 13-26, 2002.

GIANGASPERO, A.; SANDRI, L.; TOSSI, A. Amphipathic alpha helical antimicrobial peptides. Eur. J. Biochem., v. 268, n. 21, p. 5589-600, 2001.

GOW, N. A. et al. Candida albicans morphogenesis and host defence: discriminating invasion from colonization. Nat Rev Microbiol, v. 10, n. 2, p. 112-22, 2012.

GUILHELMELLI, F. et al. Antibiotic development challenges: the various mechanisms of action of antimicrobial peptides and of bacterial resistance. Front Microbiol, v. 4, p. 353, 2013.

HANCOCK, R. E.; SAHL, H. G. Antimicrobial and host-defense peptides as new antiinfective therapeutic strategies. Nat. Biotechnol., v. 24, n. 12, p. 1551-7, 2006.

HARBARTH, S. et al. Antibiotic research and development: business as usual? J. Antimicrob. Chemother., Feb 102015.

HESS, B. et al. LINCS: a linear constraint solver for molecular simulations. J. Comput. Chem., v. 18, n. 12, p. 1463-1472, 1997.

HESS, B. et al. GROMACS 4: algorithms for highly efficient, load-balanced, and scalable molecular simulation. J. Chem. Theory Comput., v. 4, n. 3, p. 435-47, 2008.

HILPERT, K.; HANCOCK, R. E. Use of luminescent bacteria for rapid screening and characterization of short cationic antimicrobial peptides synthesized on cellulose using peptide array technology. Nat Protoc, v. 2, n. 7, p. 1652-60, 2007.

HILPERT, K. et al. High-throughput generation of small antibacterial peptides with improved activity. Nat. Biotechnol., v. 23, n. 8, p. 1008-12, 2005. 
HILPERT, K.; WINKLER, D. F.; HANCOCK, R. E. Peptide arrays on cellulose support: SPOT synthesis, a time and cost efficient method for synthesis of large numbers of peptides in a parallel and addressable fashion. Nat Protoc, v. 2, n. 6, p. 1333-49, 2007.

HORI, Y. et al. Interaction of mastoparan with membranes studied by $1 \mathrm{H}-\mathrm{NMR}$ spectroscopy in detergent micelles and by solid-state $2 \mathrm{H}-\mathrm{NMR}$ and $15 \mathrm{~N}-\mathrm{NMR}$ spectroscopy in oriented lipid bilayers. Eur. J. Biochem., v. 268, n. 2, p. 302-9, 2001.

HUANG, P.; PEREZ, J. J.; LOEW, G. H. Molecular dynamics simulations of phospholipid bilayers. J. Biomol. Struct. Dyn., v. 11, n. 5, p. 927-56, 1994.

HUANG, Y.; HUANG, J.; CHEN, Y. Alpha-helical cationic antimicrobial peptides: relationships of structure and function. Protein Cell, v. 1, n. 2, p. 143-52, 2010.

HUTTNER, A. et al. Antimicrobial resistance: a global view from the 2013 World Healthcare-Associated Infections Forum. Antimicrob Resist Infect Control, v. 2, p. 31, 2013.

IRAZAZABAL, L. N. et al. Selective amino acid substitution reduces cytotoxicity of the antimicrobial peptide mastoparan. Biochim Biophys Acta, 2016.

JONASSEN, I.; COLLINS, J. F.; HIGGINS, D. G. Finding flexible patterns in unaligned protein sequences. Protein Sci., v. 4, n. 8, p. 1587-95, 1995.

KATAYAMA, H. et al. Significance of a carboxyl-terminal amide moiety in the folding and biological activity of crustacean hyperglycemic hormone. Peptides, v. 23, n. 9, p. 1537-46, 2002.

KAYSER, F. H. et al. Medical microbiology. New York: Thieme, 2005.

KHANDELIA, H.; IPSEN, J. H.; MOURITSEN, O. G. The impact of peptides on lipid membranes. Biochim Biophys Acta, v. 1778, n. 7-8, p. 1528-36, 2008.

KHANDELIA, H.; KAZNESSIS, Y. N. Molecular dynamics investigation of the influence of anionic and zwitterionic interfaces on antimicrobial peptides' structure: implications for peptide toxicity and activity. Peptides, v. 27, n. 6, p. 1192-200, 2006.

KNAPPE, D. et al. Easy strategy to protect antimicrobial peptides from fast degradation in serum. Antimicrob Agents Chemother, v. 54, n. 9, p. 4003-5, 2010.

KONNO, K.; KAZUMA, K.; NIHEI, K. Peptide toxins in solitary wasp Venoms. Toxins (Basel), v. 8, n. 4, 2016.

KORADI, R.; BILLETER, M.; WUTHRICH, K. MOLMOL: a program for display and analysis of macromolecular structures. J. Mol. Graph., v. 14, n. 1, p. 51-5, 29-32, 1996.

KOSIKOWSKA, P.; LESNER, A. Antimicrobial peptides (AMPs) as drug candidates: a patent review (2003-2015). Expert Opin Ther Pat, v. 26, n. 6, p. 689-702, 2016. 
KUMARIYA, R. et al. Increased membrane surface positive charge and altered membrane fluidity leads to cationic antimicrobial peptide resistance in Enterococcus faecalis. Biochim. Biophys. Acta, v. 1848, n. 6, p. 1367-75, 2015.

KYTE, J.; DOOLITTLE, R. F. A simple method for displaying the hydropathic character of a protein. J. Mol. Biol., v. 157, n. 1, p. 105-32, 1982.

LANGHAM, A.; KAZNESSIS, Y. N. Molecular simulations of antimicrobial peptides. Methods Mol. Biol., v. 618, p. 267-85, 2010.

LASKOWSKI, R. A. et al. PROCHECK-a program to check the stereochemical quality of protein structures. J. Appl. Crystallogr., v. 26, p. 283-291, 1993.

LATA, S.; MISHRA, N. K.; RAGHAVA, G. P. AntiBP2: improved version of antibacterial peptide prediction. BMC Bioinformatics, v. 11 Suppl 1, p. S19, 2010.

LEE, T. H.; HALL, K. N.; AGUILAR, M. I. Antimicrobial Peptide Structure and Mechanism of Action: A Focus on the Role of Membrane Structure. Curr Top Med Chem, v. 16, n. 1, p. 25-39, 2016.

LEITE, N. B. et al. The effect of acidic residues and amphipathicity on the lytic activities of mastoparan peptides studied by fluorescence and CD spectroscopy. Amino Acids, v. 40, n. 1, p. 91-100, 2011.

LI, M. L. et al. Antimicrobial activity of synthetic all-D mastoparan M. Int. J. Antimicrob. Agents, v. 13, n. 3, p. 203-8, 2000.

LIN, C. H. et al. Structural and biological characterization of mastoparans in the venom of Vespa species in Taiwan. Peptides, v. 32, n. 10, p. 2027-36, 2011.

LINGE, J. P. et al. Refinement of protein structures in explicit solvent. Proteins, v. 50, n. 3, p. 496-506, 2003.

LOOSE, C. et al. A linguistic model for the rational design of antimicrobial peptides. Nature, v. 443, n. 7113, p. 867-9, 2006.

LORIN, C. et al. The antimicrobial peptide dermaseptin S4 inhibits HIV-1 infectivity in vitro. Virology, v. 334, n. 2, p. 264-75, 2005.

MAI, X. T. et al. Effects and mechanisms of the secondary structure on the antimicrobial activity and specificity of antimicrobial peptides. J Pept Sci, v. 21, n. 7, p. 561-8, 2015.

MANDAL, S. M. et al. Controlling resistant bacteria with a novel class of beta-lactamase inhibitor peptides: from rational design to in vivo analyses. Sci Rep, v. 4, p. 6015, 2014.

MANGONI, M. L. et al. Effect of natural L- to D-amino acid conversion on the organization, membrane binding, and biological function of the antimicrobial peptides bombinins $\mathrm{H}$. Biochemistry, v. 45, n. 13, p. 4266-76, 2006. 
MARIA-NETO, S. et al. Deciphering the magainin resistance process of Escherichia coli strains in light of the cytosolic proteome. Antimicrob. Agents Chemother., v. 56, n. 4, p. 1714-24, 2012.

MARR, A. K.; GOODERHAM, W. J.; HANCOCK, R. E. Antibacterial peptides for therapeutic use: obstacles and realistic outlook. Curr Opin Pharmacol, v. 6, n. 5, p. 468-72, 2006.

MELLOR, I. R.; SANSOM, M. S. Ion-channel properties of mastoparan, a 14-residue peptide from wasp venom, and of MP3, a 12-residue analogue. Proc. R. Soc. Lond. B. Biol. Sci., v. 239, n. 1296, p. 383-400, 1990.

MELVIN, J. A.; MONTELARO, R. C.; BOMBERGER, J. M. Clinical potential of engineered cationic antimicrobial peptides against drug resistant biofilms. Expert Rev Anti Infect Ther, Sep 142016.

MIGLIOLO, L. et al. Structural and functional evaluation of the palindromic alanine-rich antimicrobial peptide Pa-MAP2. Biochim Biophys Acta, v. 1858, n. 7 Pt A, p. 1488-98, Jul 2016.

MISHRA, N. N. et al. Daptomycin resistance in enterococci is associated with distinct alterations of cell membrane phospholipid content. PLoS One, v. 7, n. 8, p. e43958, 2012.

MIYAMOTO, S.; KOLLMAN, P. A. SETTLE: an analytical version of the SHAKE and RATTLE algorithm for rigid water models. J. Comput. Chem., v. 13, n. 8, p. 952-962, 1992.

MOOKHERJEE, N.; HANCOCK, R. E. Cationic host defence peptides: innate immune regulatory peptides as a novel approach for treating infections. Cell. Mol. Life Sci., v. 64, n. 7-8, p. 922-33, 2007.

NABUURS, S. B. et al. Quantitative evaluation of experimental NMR restraints. J Am Chem Soc, v. 125, n. 39, p. 12026-34, Oct 12003.

NABUURS, S. B. et al. Concepts and tools for NMR restraint analysis and validation. Concepts Magn. Reson., v. 22A, n. 2, p. 90-105, 2004.

NCCLS. Metodologia dos testes de sensibilidade a agentes antimicrobianos por diluição para bactéria de crescimento aeróbico; norma aprovada-Sexta edição 2003. 23 ISBN 156238-486-4. 940 West Valley Road, Suite 1400, Wayne, Pennsylvania 19087-1898 USA NCCLS document M7-A6Disponível em: http://sbac.org.br/imagens/bibliotecas/clsi_OPASM7_A6.pdf $>$.

NGUYEN, L. T.; HANEY, E. F.; VOGEL, H. J. The expanding scope of antimicrobial peptide structures and their modes of action. Trends Biotechnol., v. 29, n. 9, p. 464-72, 2011.

NICOLAS, P. Multifunctional host defense peptides: intracellular-targeting antimicrobial peptides. FEBS J., v. 276, n. 22, p. 6483-96, 2009. 
NIZET, V. Antimicrobial peptide resistance mechanisms of human bacterial pathogens. Curr Issues Mol Biol, v. 8, n. 1, p. 11-26, 2006.

OPPENHEIM, J. J.; YANG, D. Alarmins: chemotactic activators of immune responses. Curr Opin Immunol, v. 17, n. 4, p. 359-65, 2005.

PACE, C. N.; SCHOLTZ, J. M. A helix propensity scale based on experimental studies of peptides and proteins. Biophys. J., v. 75, n. 1, p. 422-7, 1998.

PAPO, N.; SHAI, Y. Can we predict biological activity of antimicrobial peptides from their interactions with model phospholipid membranes? Peptides, v. 24, n. 11, p. 1693-703, 2003.

PARK, S. C.; PARK, Y.; HAHM, K. S. The role of antimicrobial peptides in preventing multidrug-resistant bacterial infections and biofilm formation. Int J Mol Sci, v. 12, n. 9, p. 5971-92, 2011.

PASUPULETI, M.; SCHMIDTCHEN, A.; MALMSTEN, M. Antimicrobial peptides: key components of the innate immune system. Crit. Rev. Biotechnol., v. 32, n. 2, p. 143-71, 2012.

PATEL, S. et al. Patenting computer-designed peptides. J. Comput. Aided Mol. Des., v. 12, n. 6, p. 543-56, 1998.

PESCHEL, A.; SAHL, H. G. The co-evolution of host cationic antimicrobial peptides and microbial resistance. Nat. Rev. Microbiol., v. 4, n. 7, p. 529-36, 2006.

PORTO, W. GRAMMATICAL e Joker: Duas Novas Ferramentas para Desenho Racional de Peptídeos Antimicrobianos. 2013. 104 (Dissertação de Mestrado). Universidade Católica de Brasília, Brasília-DF.

PORTO, W. F.; PIRES, A. S.; FRANCO, O. L. CS-AMPPred: an updated SVM model for antimicrobial activity prediction in cysteine-stabilized peptides. PLoS One, v. 7, n. 12, p. e51444, 2012.

PORTO, W. F. F., F. C. ; FRANCO, O. L. . An SVM Model Based on Physicochemical Properties to Predict Antimicrobial Activity from Protein Sequences with Cysteine Knot Motifs. Lecture Notes in Computer Science, v. 6268, p. 59-62, 2010.

POWERS, J. P.; HANCOCK, R. E. The relationship between peptide structure and antibacterial activity. Peptides, v. 24, n. 11, p. 1681-91, Nov 2003.

RAMACHANDRAN, G. N.; RAMAKRISHNAN, C.; SASISEKHARAN, V. Stereochemistry of polypeptide chain configurations. J. Mol. Biol., v. 7, p. 95-9, 1963.

RAMAKRISHNAN, C.; RAMACHANDRAN, G. N. Stereochemical criteria for polypeptide and protein chain conformations. II. Allowed conformations for a pair of peptide units. Biophys. J., v. 5, n. 6, p. 909-33, 1965. 
REDDY, K. V.; YEDERY, R. D.; ARANHA, C. Antimicrobial peptides: premises and promises. Int. J. Antimicrob. Agents, v. 24, n. 6, p. 536-47, 2004.

REINERT, R. R. et al. Antimicrobial susceptibility among organisms from the Asia/Pacific Rim, Europe and Latin and North America collected as part of TEST and the in vitro activity of tigecycline. J Antimicrob Chemother, v. 60, n. 5, p. 1018-29, 2007.

REX, S. Pore formation induced by the peptide melittin in different lipid vesicle membranes. Biophys. Chem., v. 58, n. 1-2, p. 75-85, 1996.

RICE, L. B. The clinical consequences of antimicrobial resistance. Curr. Opin. Microbiol., v. 12, n. 5, p. 476-81, 2009.

ROSSI, F. The challenges of antimicrobial resistance in Brazil. Clin. Infect. Dis., v. 52, n. 9, p. 1138-43, 2011.

SCHMIDTCHEN, A. et al. Boosting antimicrobial peptides by hydrophobic oligopeptide end tags. J Biol Chem, v. 284, n. 26, p. 17584-94, 2009.

SFORCA, M. L. et al. How C-terminal carboxyamidation alters the biological activity of peptides from the venom of the eumenine solitary wasp. Biochemistry, v. 43, n. 19, p. 5608-17, 2004.

SHEN, Y. et al. TALOS+: a hybrid method for predicting protein backbone torsion angles from NMR chemical shifts. J. Biomol. NMR, v. 44, n. 4, p. 213-23, 2009.

SHIBATA, N. et al. Existence of branched side chains in the cell wall mannan of pathogenic yeast, Candida albicans. Structure-antigenicity relationship between the cell wall mannans of Candida albicans and Candida parapsilosis. J Biol Chem, v. 270, n. 3, p. 111322, 1995.

SHIBATA, N.; KOBAYASHI, H.; SUZUKI, S. Immunochemistry of pathogenic yeast, Candida species, focusing on mannan. Proc Jpn Acad Ser B Phys Biol Sci, v. 88, n. 6, p. 250-65, 2012.

SILVA, O. N. et al. Exploring the pharmacological potential of promiscuous host-defense peptides: from natural screenings to biotechnological applications. Front. Microbiol., v. 2, p. 232, 2011.

SIMS, P. J. et al. Studies on the mechanism by which cyanine dyes measure membrane potential in red blood cells and phosphatidylcholine vesicles. Biochemistry, v. 13, n. 16, p. 3315-30, 1974.

SODING, J.; BIEGERT, A.; LUPAS, A. N. The HHpred interactive server for protein homology detection and structure prediction. Nucleic Acids Res, v. 33, n. Web Server issue, p. W244-8, 2005.

SPRONK, C. A. et al. The precision of NMR structure ensembles revisited. J. Biomol. NMR, v. 25, n. 3, p. 225-34, 2003. 
TENOVER, F. C. Mechanisms of antimicrobial resistance in bacteria. Am. J. Med., v. 119, n. 6 Suppl 1, p. S3-10; discussion S62-70, 2006.

THEVISSEN, K.; TERRAS, F. R.; BROEKAERT, W. F. Permeabilization of fungal membranes by plant defensins inhibits fungal growth. Appl. Environ. Microbiol., v. 65, n. 12, p. 5451-8, 1999.

THOMAS, S. et al. CAMP: a useful resource for research on antimicrobial peptides. Nucleic Acids Res., v. 38, n. Database issue, p. D774-80, 2010.

TONG, Z. et al. An in vitro study on the effects of nisin on the antibacterial activities of 18 antibiotics against Enterococcus faecalis. PLoS One, v. 9, n. 2, p. e89209, 2014.

TOSSI, A.; SANDRI, L.; GIANGASPERO, A. Amphipathic, alpha-helical antimicrobial peptides. Biopolymers, v. 55, n. 1, p. 4-30, 2000.

UEMATSU, N.; MATSUZAKI, K. Polar angle as a determinant of amphipathic alpha-helixlipid interactions: a model peptide study. Biophys J, v. 79, n. 4, p. 2075-83, 2000.

UENO, S. et al. Generation of novel cationic antimicrobial peptides from natural nonantimicrobial sequences by acid-amide substitution. Ann Clin Microbiol Antimicrob, v. 10, p. 11, 2011.

UPTON, M.; COTTER, P.; TAGG, J. Antimicrobial peptides as therapeutic agents. Int. J. Microbiol., v. 2012, p. 326503, 2012.

VAN DE LOOSDRECHT, A. A. et al. Cell mediated cytotoxicity against U 937 cells by human monocytes and macrophages in a modified colorimetric MTT assay. A methodological study. J. Immunol. Methods, v. 141, n. 1, p. 15-22,

1991.

VAN GUNSTEREN, W. F.; BERENDSEN, H. J. C. A leap-frog algorithm for stochastic dynamics. Mol. Simul., v. 1, n. 3, p. 173-185, 1988.

VENTOLA, C. L. The antibiotic resistance crisis: part 1: causes and threats. P T, v. 40, n. 4, p. 277-83, 2015.

WANG, G.; LI, X.; WANG, Z. APD2: the updated antimicrobial peptide database and its application in peptide design. Nucleic Acids Res., v. 37, n. Database issue, p. D933-7, 2009.

WEBB, B.; SALI, A. Comparative protein structure modeling using MODELLER. Curr. Protoc. Bioinformatics, v. 47, p. 5. 6. 1-5 6. 32, 2014.

WHO. Report on the burden of endemic health care-associated infection worldwide. 2011 
WIEDERSTEIN, M.; SIPPL, M. J. ProSA-web: interactive web service for the recognition of errors in three-dimensional structures of proteins. Nucleic Acids Res., v. 35, n. Web Server issue, p. W407-10, 2007.

WIMLEY, W. C. Describing the mechanism of antimicrobial peptide action with the interfacial activity model. ACS Chem. Biol., v. 5, n. 10, p. 905-17, 2010.

WINKLER, D. F. et al. Synthesis of peptide arrays using SPOT-technology and the CelluSpots-method. Methods Mol. Biol., v. 570, p. 157-74, 2009.

WISHART, D. S.; SYKES, B. D.; RICHARDS, F. M. The chemical shift index: a fast and simple method for the assignment of protein secondary structure through NMR spectroscopy. Biochemistry, v. 31, n. 6, p. 1647-51, 1992.

WU, E. L. et al. CHARMM-GUI membrane builder toward realistic biological membrane simulations. J. Comput. Chem., v. 35, n. 27, p. 1997-2004, 2014.

WUTHRICH, K. Sequential individual resonance assignments in the $1 \mathrm{H}-\mathrm{nmr}$ spectra of polypeptides and proteins. Biopolymers, v. 22, n. 1, p. 131-8, 1983.

YEAMAN, M. R.; YOUNT, N. Y. Mechanisms of antimicrobial peptide action and resistance. Pharmacol. Rev., v. 55, n. 1, p. 27-55, 2003.

YOUNT, N. Y.; YEAMAN, M. R. Immunocontinuum: perspectives in antimicrobial peptide mechanisms of action and resistance. Protein Pept Lett, v. 12, n. 1, p. 49-67, 2005.

ZASLOFF, M. Antimicrobial peptides of multicellular organisms. Nature, v. 415, n. 6870, p. 389-95, 2002.

ZELEZETSKY, I. et al. Tuning the biological properties of amphipathic alpha-helical antimicrobial peptides: rational use of minimal amino acid substitutions. Peptides, v. 26, n. 12, p. 2368-76, 2005.

ZHANG, L.; FALLA, T. J. Antimicrobial peptides: therapeutic potential. Expert Opin Pharmacother, v. 7, n. 6, p. 653-63, 2006. 


\section{Apêndice I- Figuras complementárias}

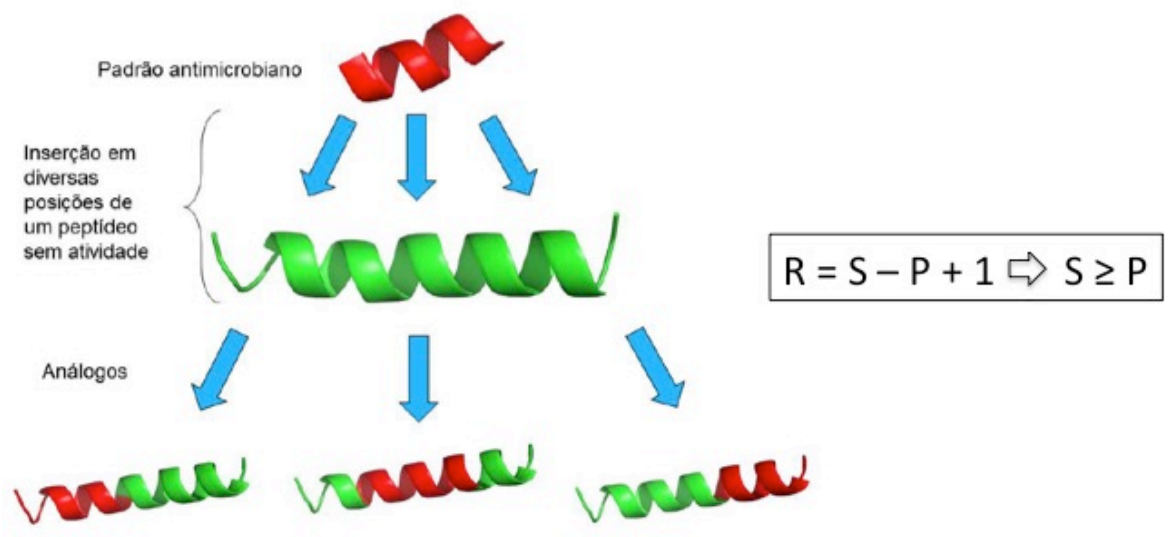

Figura 1. Representação esquemática do funcionamento do algoritmo Joker e equação do número máximo de análogos para o peptídeo original. O número de análogos está representado por $\mathrm{R}$, o número de aminoácidos da sequência por $\mathrm{S}$ e o número de componentes do padrão por $\mathrm{P}$. Adaptado de Porto, 2013.

Tabela 1. Atividade antimicrobiana das sequências geradas por desenho racional, avaliada pela técnica spot array frente a bactéria bioluminiscente P. aeruginosa H1001. As sequências selecionadas encontram-se ressaltadas em letra escura.

\begin{tabular}{|c|c|c|}
\hline Nome & Sequência & CIM P. aeruginosa $\mathrm{H} 1001(\mu \mathrm{M})$ \\
\hline$\left[I^{5}, R^{8}\right] M P$ & INLKILARLAKKIL & 6 \\
\hline PaDBS1 & MARNKPGKKLRLAAAFK & $>200$ \\
\hline PaDBS1R1 & PKILNKILGKILRLAAAFK & 6 \\
\hline PaDBS1R2 & PMARKILLRIKLKIAAAFK & 50 \\
\hline PaDBS1R3 & PMARNKILGKILRKIAAFK & 6,25 \\
\hline PaDBS1R4 & PMARNKPKILKRILAKIFK & 6,25 \\
\hline PaDBS1R5 & PMARNKPLKILLRLAAKIK & 12,5 \\
\hline PaDBS1R6 & PMARNKPLGKILRRIAAKI & 12,5 \\
\hline PaDBS1R7 & PMKLLKRLGKKIRLAAAFK & 3 \\
\hline PaDBS1R8 & PMAKLLPRIKKKILAAAFK & 12,5 \\
\hline PaDBS1R9 & PMARNKKLLKKLRLKIAFK & 1,5 \\
\hline ECDBS 1 & MKKLFAALALAAVVAPVW & 200 \\
\hline EcDBS1R1 & PMKKLLARLALKIVVAPVW & 25 \\
\hline EcDBS1R2 & PMKKKLAARILAKIVAPVW & 12,5 \\
\hline EcDBS1R3 & PMKKLKLALRLAAKIAPVW & 12,5 \\
\hline ECDBS1R4 & PMKKLFAALKLAARVAPKI & 12,5 \\
\hline EcDBS1R5 & PMKKLFAKLALRIVVKIVW & 200 \\
\hline EcDBS1R6 & PMKKLFKLLARIAVKIPVW & 6,25 \\
\hline ECDBS1R7 & PMKKLFAALKLAARVAPKI & 200 \\
\hline EcDBS 1R8 & PMKILFRI LAKIAVVAPVW & 100 \\
\hline ECDBS1R9 & PMKKLFAAKILARVVAKIW & 6,25 \\
\hline
\end{tabular}


A)

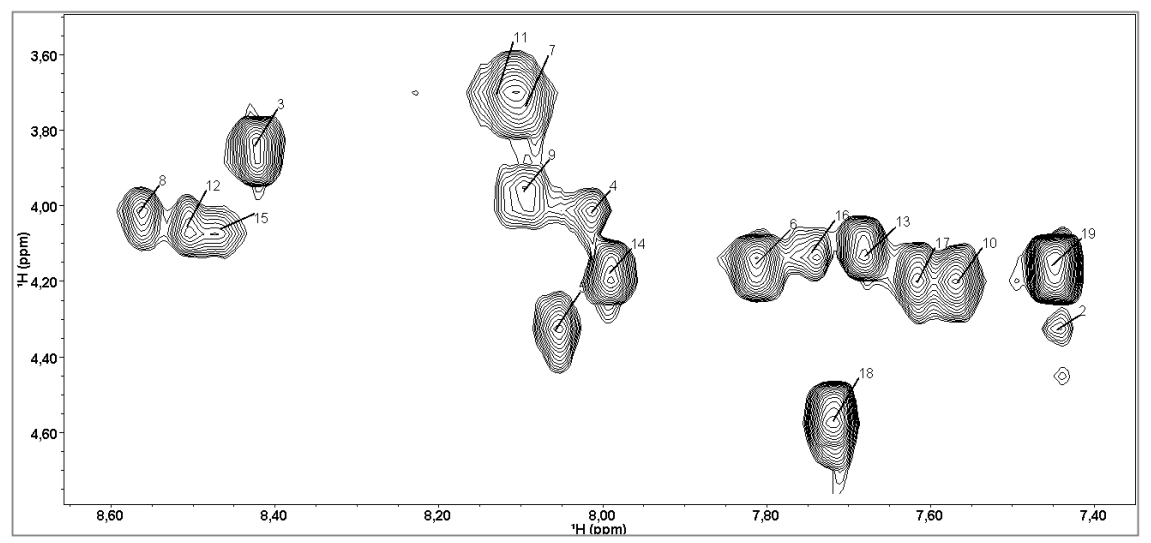

B)

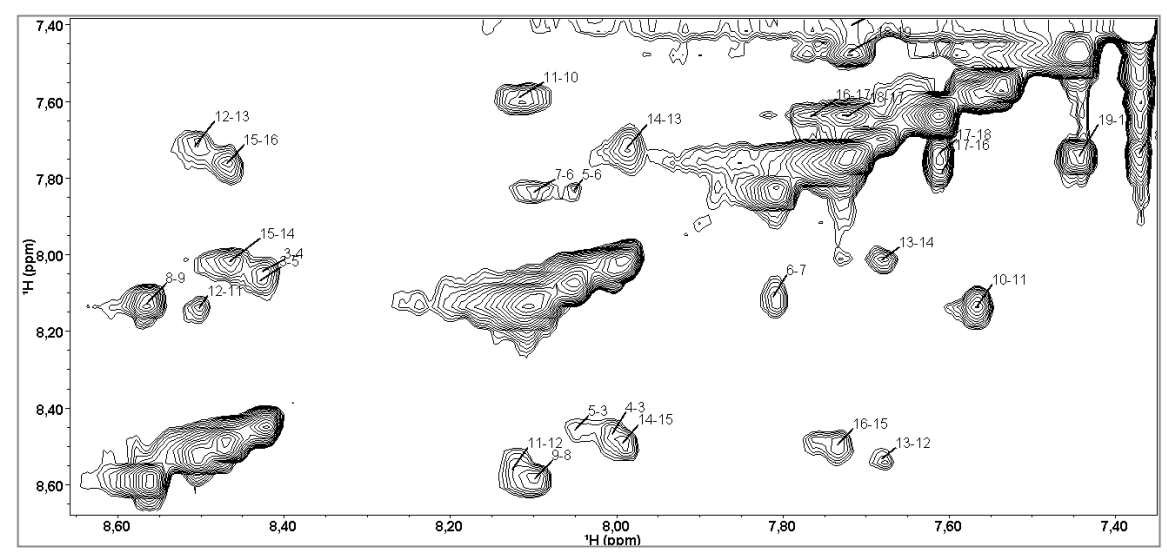

C)

$\begin{array}{lllllllllllllllllll}1 & 2 & 3 & 4 & 5 & 6 & 7 & 8 & 9 & 10 & 11 & 12 & 13 & 14 & 15 & 16 & 17 & 18 & 19 \\ \mathrm{P} & \mathrm{K} & \mathrm{I} & \mathrm{L} & \mathrm{N} & \mathrm{K} & \mathrm{I} & \mathrm{L} & \mathrm{G} & \mathrm{K} & \mathrm{I} & \mathrm{L} & \mathrm{R} & \mathrm{L} & \mathrm{A} & \mathrm{A} & \mathrm{A} & \mathrm{F} & \mathrm{K}\end{array}$

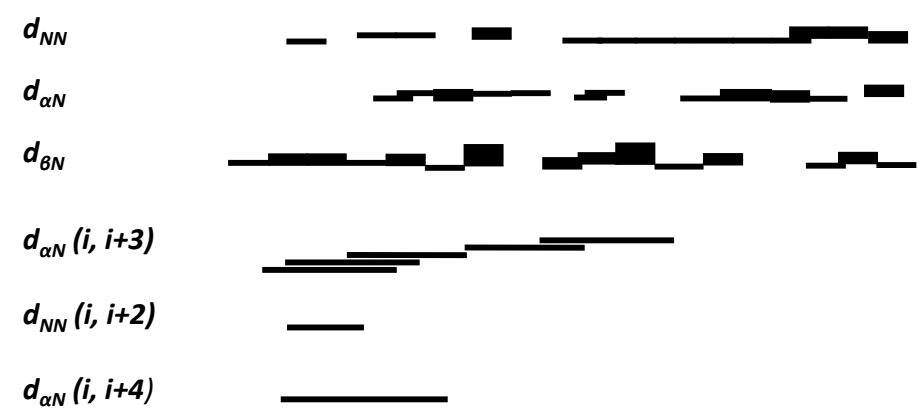

Figura 2. (A) mapa de contornos TOCSY e (B) NOESY obtidos para 1 mmol.L ${ }^{-1}$ do peptídeo PaDBS1R1 em presença de $100 \mathrm{mmol}$. $\mathrm{L}^{-1}$ de SDS-d $\mathrm{d}_{25}$. (C) Diagrama de conectividades NOE. As intensidades das interações $\mathrm{d}_{\mathrm{NN}}, \mathrm{d}_{\alpha \mathrm{N}}$ e $\mathrm{d}_{\beta \mathrm{N}}$ estão diferenciadas como fortes, médias e fracas de acordo com a espessura das linhas. 
A)

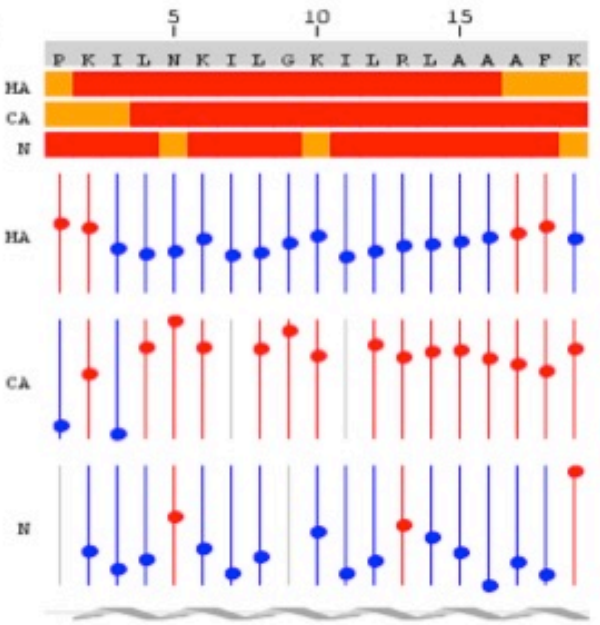

C)

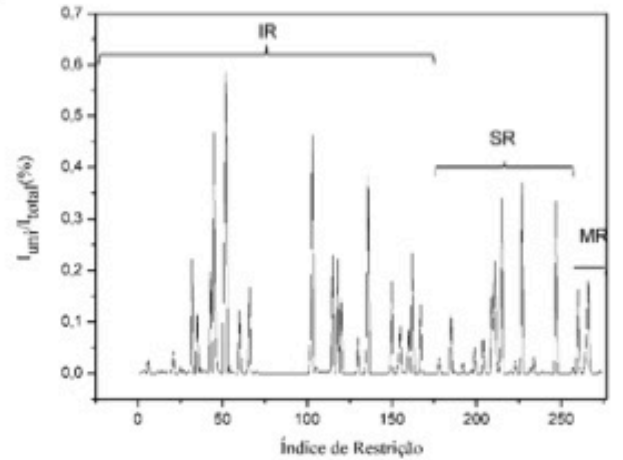

B) NOE RESTRAINS

\begin{tabular}{|c|c|}
\hline $\begin{array}{l}\text { Total number of distance Restrains } \\
\text { Number of intraresidue restrains }\end{array}$ & $\begin{array}{l}278 \\
175\end{array}$ \\
\hline Number of sequential restrains $(i, i+1)$ & 84 \\
\hline Number of medium range restrains $(i, i+j)_{j-2,3,4}$ & 18 \\
\hline Number of long range restrains $(|i-j|>5)$ & 0 \\
\hline Dihedral angles & 34 \\
\hline Hydrogen Bonds & 0 \\
\hline RIMSD $(A)^{\prime \prime}$ - All residues & \\
\hline $\begin{array}{l}\text { Backbone } \\
\text { Backbone and heavy atoms } \\
\text { RMSD }(A)^{\mathrm{a}, \mathrm{b}} \text { - Helical segment }\end{array}$ & $\begin{array}{l}0.77 \pm 0.26 \\
1.46 \pm 0.37\end{array}$ \\
\hline Backbone & $0.52 \pm 0.18$ \\
\hline $\begin{array}{l}\text { Backbone and heavy atoms } \\
\text { Ramachandran plot analysis }\end{array}$ & $1.15 \pm 0.30$ \\
\hline Residues in most favoured regions & $95.9 \%$ \\
\hline Residues in additional allowed regions & $4.1 \%$ \\
\hline Residues in generously allowed regions & $0.0 \%$ \\
\hline Residues in disallowed regions & $0.0 \%$ \\
\hline
\end{tabular}

"Data from MOLMOL using 10 lowest energy structures; "from 4-18;

data from: http:l/mordred.bioc.cam.ac.uk/ rapper/rampage.php

D)

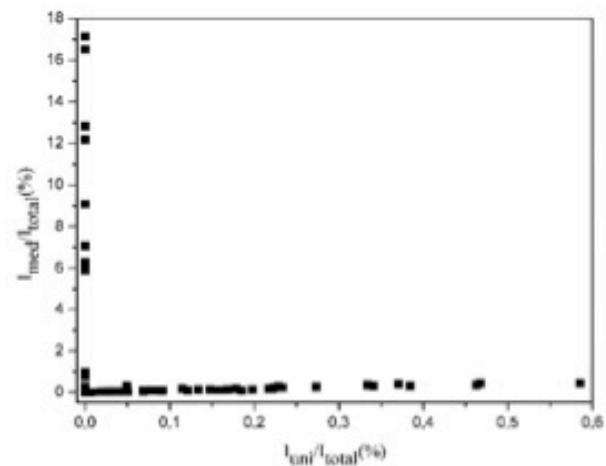

Figura 3. (A) CSI dos núcleos de $\mathrm{H}_{\alpha}, \mathrm{C}_{\alpha}$ e $\mathrm{N}$ do peptídeo PaDBS1R1. A região estrutural em hélice está indicada. (B) Resumo dos dados de cálculos estruturais das 20 melhores estruturas RMN para PaDBS1R1. (C, D) Análise das restrições de distancia e ângulos diedros obtidas por RMN. (C) Gráfico de unicidade $\left(\mathrm{I}_{\text {uni }}\right)$ pelo índice de cada restrição e (D) gráfico de informação única $\left(\mathrm{I}_{\text {uni }}\right)$ por informação média $\left(\mathrm{I}_{\mathrm{med}}\right)$, respectivamente. IR, restrições intra-residuais; SR, restrições sequenciais; MR, restrições de média distancia. 


\section{Apêndice II- Produção científica}

\section{Artigo publicado}

L.N. Irazazabal, W.F. Porto, S.M. Ribeiro, S. Casale, V. Humblot, A. Ladram, O.L. Franco. Selective amino acid substitution reduces cytotoxicity of the antimicrobial peptide mastoparan. Biochim Biophys Acta, (2016) doi:10.1016/j.bbamem.2016.07.001

\section{Patente}

Franco, Octavio L.; Irazazabal, Luz; Santana Fernandes Alves, Eliane; Porto Farias, William; Lima, Milene A.; Morais Liao, Luciano; Meira Ribeiro, Suzana; Fensterseifer, Isabel C. "PEPTÍDEOS ANÁlOGOS DE PYROBACULUM E SEUS USOS COMO ANTIMICROBIANO". Data de depósito: 02/06/2016. Número de registro: BR 102016

012571-5. Depositante/Titular: União Brasiliense de Educação e Cultura - UBEC, Silvania, GO. 